\title{
MOVEMENT AND SURVIVAL OF CAPTIVE-REARED \\ GHARIAL Gavialis gangeticus IN THE NARAYANI RIVER, NEPAL
}

\section{By}

TIRTHA MAN MASKEY

A DISSERTATION PRESENTED TO THE GRADUATE SCHOOL OF THE UNIVERSITY OF FLORIDA IN PARTIAL FULFILLMENT OF THE REQUIREMENTS FOR THE DEGREE OF DOCTOR OF PHILOSOPHY

UNIVERSITY OF FLORIDA 


\section{ACKNOWLEDGMENTS}

I express my sincere gratitude and respect to His Royal Highness Prince Gyanendra Bir Bikram Shah for his personal interest in and support of this project.

I wish to express my sincerest gratitude to those many individuals who provided assistance throughout my tenure as a graduate student in the Department of Wildlife and Range Sciences. H. F. Percival, my graduate advisor, guided, encouraged and supported me during both my course work and field work in Nepal. This dissertation would not have been completed without his effort and review. C. L. Abercrombie, who visited my research site in Nepal in December 1986, assisted in the field implementation of the radio-telemetry study of gharials. R. F. Labisky visited in June 1987, at which time he reviewed the data collection system, designed the riverine habitat survey, and contributed to development of the dissertation outline. Other members of my graduate committee, F. W. King, M. E. Sunquist, L. D. Harris and C. A. Woods graciously assisted me throughout all phases of my research from initial development and discussion of research topics to critical review of my dissertation. A. W. Woodward of the Florida Game and Fresh Water Fish Commission reviewed my dissertation and made valuable suggestions. 
K. M. Portier and J. F. Boucher provided statistical guidance throughout this study.

This research was generously supported by several organizations and individuals. I wish to thank the United States Agency for International Development (USAID), especially Dennis Brannon (then Director, country representative for USAID) and Hemanta Mishra (Secretary Member, King Mahendra Trust for Nature Conservation) for their personal interest in this project, and for development of funding through the South East Consortium for International Development (SECID) at Duke University. I am also grateful to Arthur Jones (Jumbolair Farm), Florida Cooperative Fish and Wildlife Research Unit (FCFWRU), Jesse Smith Noyes Foundation, King Mahendra Trust for Nature Conservation, Frankfurt Zoological Society, Smithsonian Institution, World Wildlife Fund USA, and International Trust for Nature Conservation for their generous contributions to this project.

I am also grateful to B. N. Upreti, R. P. Yadav, K. M. Shrestha, J. Bauer, D. Smith, C. Wemmer, I. Taylor, C. McDougal, F. Sunquist, and M. Iijima for their cooperation and advice during the 10 years of this research effort. E. Jacobson (School of Veterinary Medicine, University of Florida) and P. Moler (Florida Game and Fresh Water Fish Commission) assisted in the development of the radiotransmitter implant procedures in alligators. M. Shrestha 
(veterinarian, Narayanghat, Nepal) assisted with implant surgery at the field site in Nepal.

P. Pradhan, D. Skinner, L. Bates and K. Silver from SECID and B. Fesler of FCFWRU helped overcome the many problems faced by an international student conducting research in a remote site in a distant country.

My field assistants were invaluable throughout this project. K. Ogura, a graduate student from Tokyo University, assisted me during the 1986-1987 study period. K. Gurung, Chowkidar and other members of the project staff invaluably helped to collect the data on status and nesting of wild gharials and movement of released gharials. J. P. Amatya and T. Mukhia provided the past history of the gharial in the Narayani River. Y. Gurung (Manager, Tiger Tops Jungle Lodge) and P. Shrestha (Managing Director, Machan Lodge) graciously provided help during my study period in Royal Chitwan National Park.

Finally, I thank my wife, Laxmi, for her continuous support throughout my graduate study. Her achievement in helping our two children and me while I completed my degree was a far greater accomplishment than mine. 
TABLE OF CONTENTS

Page

ACKNOWLEDGMENTS......................... ii

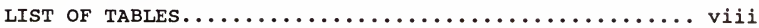

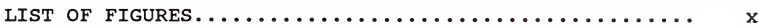

ABSTRACT $\ldots \ldots \ldots \ldots \ldots \ldots \ldots \ldots \ldots \ldots \ldots \ldots \ldots \ldots \ldots \ldots \ldots \ldots \ldots \ldots \ldots \ldots$ CHAPTERS

I INTRODUCTION $\ldots \ldots \ldots \ldots \ldots \ldots \ldots \ldots \ldots \ldots \ldots \ldots \ldots \ldots \ldots \ldots$

General Background............... 1

II STUDY AREA.......................... 6

Location and Topography............ 6

Historical Background............... 9

Geology and soil................... 12

climate....................... 13

Hydrology..................... 17

vegetation..................... 21

Sal and Hill Forest............ 21

Riverine Forest.............. 22

Grassland.................. 23

Fauna...................... 24

III STATUS OF THE WILD GHARIAL IN SOUTH ASIA.... 26

Taxonomy..................... 26

Geological origin and Phylogeny....... 27

Past and Present Distribution.......... 28

Population Status in South Asia....... 31

IV POPULATION STATUS OF THE WILD GHARIAL

IN NEPAL......................... 35

Introduction.................. 35

Methods....................... 37

Population status in Nepal.......... 39

Factors Responsible for the Decline of

Gharials................. 44 
V HABITAT SURVEY AND STATUS OF GHARIAL IN ROYAL CHITWAN NATIONAL PARK........... 51

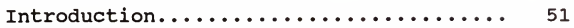

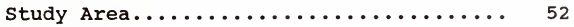

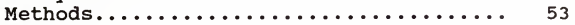

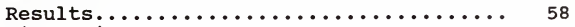

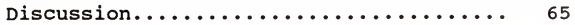

VI HUSBANDRY OF THE GHARIAL IN ROYAL CHITWAN NATIONAL PARK........................ 69

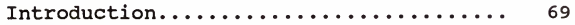

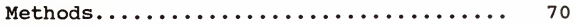

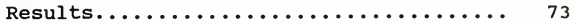

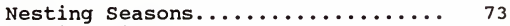

Nesting sites...................... 73

Clutch and Egg Characteristics..... 75

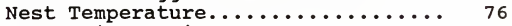

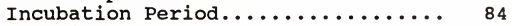

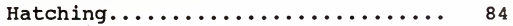

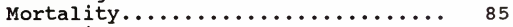

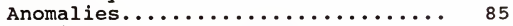

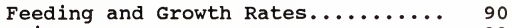

Discussion..................... 93

VII REINTRODUCTION OF CAPTIVE-REARED GHARIALS

INTO THE NARAYANI RIVER NEPAL............. 100

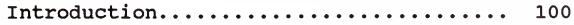

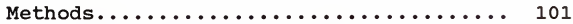

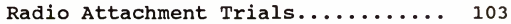

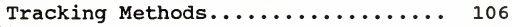

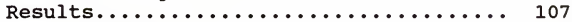

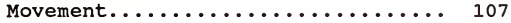

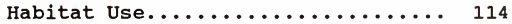

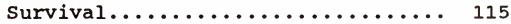

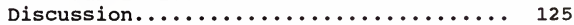

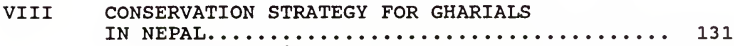

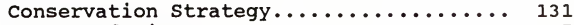

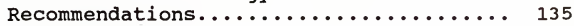

Future program.................. 142 
APPENDICES

A CHECKLIST OF MAMMALS OF ROYAL CHITWAN

NATIONAL PARK........................ 144

B CHECKLIST OF THE AMPHIBIANS AND REPTILES

OF ROYAL CHITWAN NATIONAL PARK........... 146

C CHECKLIST OF FISHES OF ROYAL CHITWAN

NATIONAL PARK...................... 148

D NEST LOCATION, EGG LAYING DATE, CLUTCH SIZE, INCUBATION PERIOD AND HATCHING SUCCESS

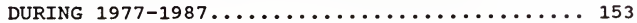

E POST-RELEASE MOVEMENT PATTERN OF RELEASED

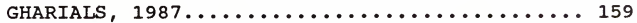

LITERATURE CITED........................... 175

BIOGRAPHICAL SKETCH....................... 186 


\section{LIST OF TABLES}

Page

3-1. The past and present status of wild and released gharials in South Asia....................

5-1. Surveys of gharials in five sectors of the Narayani and Kali rivers in 1983, 1984,

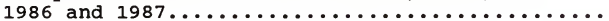

5-2. Surveys of released gharials in five sectors of the Narayani and Kali rivers in 1983, 1984, 1986,

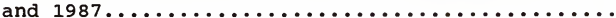

5-3. Habitat use by gharials in the Narayani River,

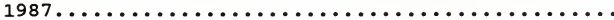

5-4. Habitat use by wild gharials in the Narayani River based on the frequency of sighting monthly,

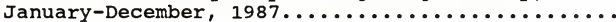

6-1. Oviposition dates for gharial clutches collected from the Narayani and Kali rivers, 1977-1987...... 74

6-2. Mean sizes of gharial clutches, Narayani and Kali

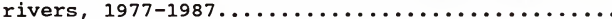

6-3. Formula for predicting one dimension of size of gharial eggs when second dimension is known.....

6-4. Mean incubation periods (in days) for gharial clutches, Narayani and Kali rivers 1977-1987....

6-5. Mean hatching success (in percent) for gharial clutches, Narayani and Kali rivers, 1977-1987...

6-6. Age-related mortality of captive gharials during the first year after hatching, Royal Chitwan

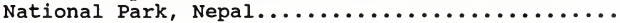

6-7. Age-related mortality of captive gharials during the second year after hatching, Royal Chitwan National Park, Nepal. 
7-1. Numbers of gharials released in different river

systems of Nepal, 1981-1987............... 103

7-2. Duration of functioning (in days) of radio-

transmitters implanted in 19 gharials.......... 109

7-3. Habitat use by gharials released into the

Narayani River, $1981 \ldots . . . \ldots . . . . . . . . . . .119$

7-4. Habitat use by gharials released into the Narayani

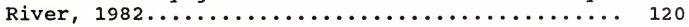

7-5. Habitat use by gharials released into the Narayani

River, $1987 . \ldots \ldots \ldots \ldots \ldots \ldots \ldots \ldots \ldots \ldots \ldots \ldots . \ldots \ldots 121$

7-6. Percentage use of habitats by male and female released gharials, $1987 \ldots \ldots \ldots \ldots \ldots \ldots \ldots \ldots \ldots \ldots . \ldots 22$

7-7. Percentage use of habitats by size class 1, 2, and 3 released gharials, $1987 \ldots \ldots \ldots \ldots \ldots \ldots \ldots \ldots$

7-8. Survival rate of the released gharials,

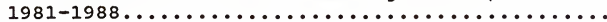




\section{LIST OF FIGURES}

Page

2-1. Location of the river systems of Nepal........ 7

2-2. Map of the Royal Chitwan National Park........ 8

2-3. Mean daily maximum and minimum ambient temperatures (with ranges) at Rampur (about $16 \mathrm{~km} \mathrm{NW}$ of

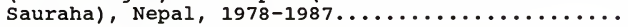

2-4. Mean daily values of percentage relative humidity (with ranges) at $10 \mathrm{AM}$ at Rampur (about $16 \mathrm{~km} \mathrm{NW}$ of Sauraha), Nepal, 1982-1987................

2-5. Mean monthly rainfall (with ranges) at Rampur (about $16 \mathrm{~km} \mathrm{NW}$ of Sauraha), Nepal, 1978-1987.... 16

2-6. Mean maximum and minimum water temperatures (with ranges) in the Narayani River, $1987 \ldots \ldots \ldots .18$

2-7. Map of the Narayani River................. 20

3-1. Past and present distribution of wild and released gharials in South Asia.................. 30

4-1. Past and present distribution of gharials in

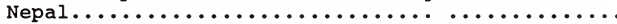

4-2. Delineation of sectors of the Kali and Narayani rivers surveyed for gharials in 1983, 1984, 1986

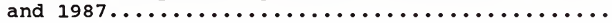

4-3. Status of wild gharial in the Narayani and Kali rivers, Nepal in 1977 (Sharma 1977) and in 1980, 1983, 1984, 1986, and 1987 (this study). Number of adult gharials, by sex are denoted (within circles) by sectors of the rivers (see Fig. 4-2). The total number of gharials surveyed by year is denoted by sum..........................

4-4. Numbers of wild gharials sighted at different localities (see Fig. 4-2) in the Narayani and

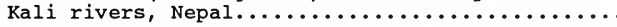

4-5. Sex ratios of gharials sighted in the Narayani and

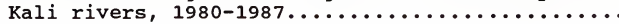


5-1. Routes for surveying gharials and habitats in the

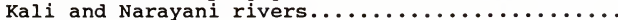

5-2. Gharial tail, showing the marking pattern used to identify released animals. (a) 1981 release (scute removal); (b) 1982 release (hole under scute); and (c) 1987 release (plastic tag) ................

6-1. Clutch size distribution of gharial nests, Narayani

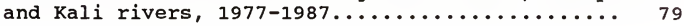

6-2. Relation between clutch size and clutch weight during the 1987 nesting season.............. 80

6-3. Relation between clutch size and egg weight during the 1987 nesting.................. 80

6-4. Mean daily ambient and nest temperatures recorded during May and June, 1987, at the hatchery site on the Narayani River.................... 81

6-5. Food intake and growth rates of gharial hatchlings, Royal Chitwan National Park, 1981 and 1982...... 91

6-6. Relation between weight and body length in

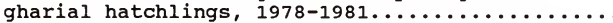

7-1. Tracking periods for 19 gharials marked with both radio-transmitter inplanted and plastic tags. Breaks indicate periods when animals were not located......................... 102

7-2. Composite of the movements of gharials released in the Narayani River, 1987................ 111

7-3. Percentage upstream and downstream movements of gharials released in the Narayani River, $1987 . \ldots$.

7-4. Percentage habitat use, by seasons, of gharials

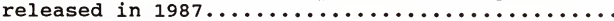

7-5. Percentage survival of gharials surviving in the

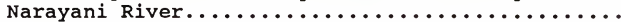


Abstract of Dissertation Presented to the Graduate School of the University of Florida in Partial Fulfillment of the Requirements for the Degree of Doctor of Philosophy

\author{
MOVEMENT AND SURVIVAL OF CAPTIVE-REARED \\ GHARIAL Gavialis gangeticus IN THE \\ NARAYANI RIVER, NEPAL
}

\author{
By
}

TIRTHA MAN MASKEY

May 1989

Chairman: H. Franklin Percival

Major Department: Forest Resources and Conservation

(Wildlife and Range Sciences)

A field study of the gharial (Gavialis gangeticus) was conducted in the Royal Chitwan National Park, Chitwan, Nepal, from 1986-1987 to determine the status and ecology of gharials in the Narayani River. Systematic surveys, conducted in December and May, revealed that a minimum of 103 ( 0.93 gharials/ km) wild and released gharials survive in the Narayani River. The sex ratio of wild gharials, 1 male: 9 females, was at a critical stage. The low numbers of males were attributed to the heavy poaching of males in the past.

Habitat surveys conducted in June, 1987 and January, 1988, indicated that, proportionately, rocky banks were the most available habitat $(0.55-0.50)$ in the Narayani River, 
followed by sand banks $(0.34-0.17)$, grass banks $(0.19-0.06)$, sand-grass banks (0.11-0.03), and river channel (0.03-0.01). Larger gharials were observed on sand banks more frequently (Mean $=79, \mathrm{SD}=15.1, \mathrm{n}=1658)$ than on rocky banks (Mean = 12.6, $\mathrm{SD}=9.6, \mathrm{n}=410$ ), whereas small gharials used rocky banks more than larger animals. Gharials are synchronized nesters with egg laying occurring from March 25-April 18. A total of 73 nests collected in the years 1977 and 1987, yielded a mean clutch size of $35.2 \pm 1.1 \mathrm{SD}$. The mean incubation periods and hatching rates of eggs from the Kali and Narayani rivers were $78 \pm 9$ SD days and 60.98, and $81 \pm$ $11.5 \mathrm{SD}$ days and $67.7 \%$ respectively. From $25 \%$ to $80 \%$ of the hatchlings died within the first year of their life.

Two areas were evaluated for reintroduction of the gharial in the Narayani River. Primary criteria used to evaluate the release site included deep, fast-flowing, clear water; high banks; deep pools; and undisturbed sand banks at the river edge. A total of 218 juvenile gharials was released (183 into the Narayani River and 35 into the Kali River) between 1981 and 1987; $52(23.8 \%)$ of these still survived in the Narayani river as of December 1987. Movement of released gharials was quite variable with respect to both distances travelled and directions of movement. Large gharials ( $>1.2 \mathrm{~m}$ in length) moved upstream $(23$ \%) more frequently than small (< $1.2 \mathrm{~m})$ animals ( 8 \%). The future success of the gharial reintroduction program in 
Nepal will be contingent on the adherence to three strategic elements: the release of gharials $>1.2 \mathrm{~m}$ in length; the selection of release sites that provide primary habitats within the principal dispersion range of the released gharials; and release of gharials in late winter to facilitate the establishment of site-fidelity bonds by individuals prior to the monsoon season. 
CHAPTER I

INTRODUCTION

General Background

The gharial, Gavialis gangeticus, a large crocodilian with a long, slender snout, is the only surviving member of a once well-represented family, Gavialidae. Claudius Aelianus, a Roman natural historian, described in 300 A.D. two types of Ganges River crocodiles (Martin and Bellairs 1977). Aelianus described one as having a "horn" on the end of its snout. As we now know, these two species were the gharial and the marsh mugger, crocodylus palustris. The adult male gharial develops a large, cartilaginous protuberance on the end of its snout, and, in fact, the name gharial originated from the resemblance of the protuberance to a ghara or earthenware pot common in India and Nepal (Smith 1931). Mystical beliefs have been attributed to the ghara in Nepal. Local tribesmen believed that a ghara placed under the pillow of expectant women relieved and speeded labor (Mishra and Maskey 1981). They also believed that when the ghara is made into incense and burned in their fields, crops are freed of insects and other pests. 
Animals are closely associated with deities in Indian and Nepalese mythology (Singh 1986). Crocodiles were regarded and worshipped as the vahana (vehicle) of the goddess Ganges. However, the growth of human populations in more recent years has overshadowed religious attachments, and the animals have been exploited for commercial values. Habitat destruction and related disturbances associated with human population growth have become serious threats to the survival of this species.

Until the early 1960s, gharials were found in all major rivers of the Indian sub-continent. Today this population has virtually disappeared. In fact, the gharial probably would be on the verge of extinction were it not for the recent gharial conservation program implemented in India (Bustard 1979) and Nepal (Maskey and Mishra 1982). Many factors contributed to the decline of the gharial population: habitat loss and disturbances; lack of strict enforcement of existing laws; killing the animal for its hide (leather) and for the ghara of the male; entrapment in nylon gill nets introduced for fishing; construction of reservoirs and dams in suitable habitat; and poaching of eggs by the local people for medicine and food. Collectively, these factors have resulted in the gharial becoming one of the rarest and most endangered crocodilians in the world. A high priority was given to this species by 
the IUCN/SSC Crocodile Specialist Group during its working meetings in South Africa (1973), Australia (1976) and India (1978). Gharials are listed as an "endangered species" in the IUCN Red Data Book (1975), and are also protected under Appendix I of the Convention on International Trade in Endangered Species of wild Fauna and Flora (CITES) (Singh 1986).

The recent decline in the numbers and distribution of the gharial has prompted considerable concern for its future. Remnant populations are presently confined to relatively small areas of the major river systems of Nepal and India. Very little is known about their ecology and behavior. Nest flooding, caused by man-induced hydrological changes, is now thought to be the principal factor limiting the population in the Narayani River of Nepal.

His Majesty's Government (HMG) of Nepal, strongly supported by the Frankfurt Zoological Society, launched its Gharial Conservation Project in Royal Chitwan National Park (RCNP) in March 1978. The project focused on egg collection prior to flooding. Subsequently, gharials were hatched and hatchlings were reared in captivity to a length of 1-2 m, and then released into the Narayani River. The Department of National Parks and Wildlife Conservation (DNPWC) of HMG Nepal believed that knowledge of the survival and adaptability of released gharials was necessary to measure the success of the conservation effort. Since 1981, 218 
gharials have been reintroduced into the Narayani and Kali rivers.

Restocking of depleted populations of crocodilians has been discussed as a viable management techniques (Nichols et al. 1976; Choudhury and Bustard 1981; and Whitaker 1987). Allen (1974) stated that historically, restocking programs generally have been regarded as an ineffective techniques in the management of wildlife populations; however, the restocking of areas with artificially hatched and reared crocodilians generally has been successful (Chabreck 1971; Pooley 1971, 1973; Nichols et al. 1976; Choudhury and Bustard 1981; Singh, Kar and Choudhury 1984). In the wild crocodilian eggs and young generally suffer very high mortality rates (Cott 1961; Pooley 1962, 1966, 1969a; Cott and Pooley 1972; Guggisburg 1972; Nichols et al. 1976). Artificial hatching and rearing can greatly reduce mortality rates of crocodilian eggs and young, and, subsequently, the animals can be reintroduced to natural populations at a size and age at which vulnerability to mortality is low (Nichols et al. 1976).

To enable the DNPWC to examine more clearly the interactive elements that influence the survival of the gharial in the river system, and to assess the success of its conservation efforts, this study was designed to address the following objectives:

1. to review the current status of the wild gharial through both published and unpublished literature; 
2. to evaluate the distribution of remnant populations and habitat use of gharials in the Narayani River;

3. to determine values of wild nest parameters, and captive hatching success of gharials in Nepal;

4. to determine dispersal patterns, movements, and survival of gharials released in the Narayani River; and

5. to evaluate the captive hatching success and release program of gharials in Nepal and make recommendations for its use in a management program. 
CHAPTER II

THE STUDY AREA

\section{Location and Topography}

The Narayani River of the Royal Chitwan National Park (RCNP) lies at approximately $84^{\circ} 20^{\prime} \mathrm{E}$ longitude and $27^{\circ} 30^{\prime} \mathrm{N}$ latitude (Fig. 2-1). RCNP covers an area of $936 \mathrm{~km}^{2}$ in the southern part of the Chitwan District. The Rapti River forms the northern boundary, and the Reu River forms a large portion of the southern boundary (Fig. 2-2). The northwestern park boundary follows the Narayani River to produce a narrow $18 \mathrm{~km}$ extension of the park encompassing that part of the river that includes a number of forested islands, the largest of which is Bandarihola. The eastern boundary crosses the Churia Hills from Hasta river on the Rapti to Shikaribas (Fig. 2-2).

The altitude of the floodplain is about $120 \mathrm{~m}$ and it rises to $815 \mathrm{~m}$ at the crest of the Churia Hills. The Park, which lies in the inner terai or dun (the word, dun, signifies the plains between two hills), is a synclinal basin between the Mahabharat Range and the Churia Range. Foothills of the Mahabharat Range, the Churia Hills, rise abruptly north of the Gangetic edge. These are the 


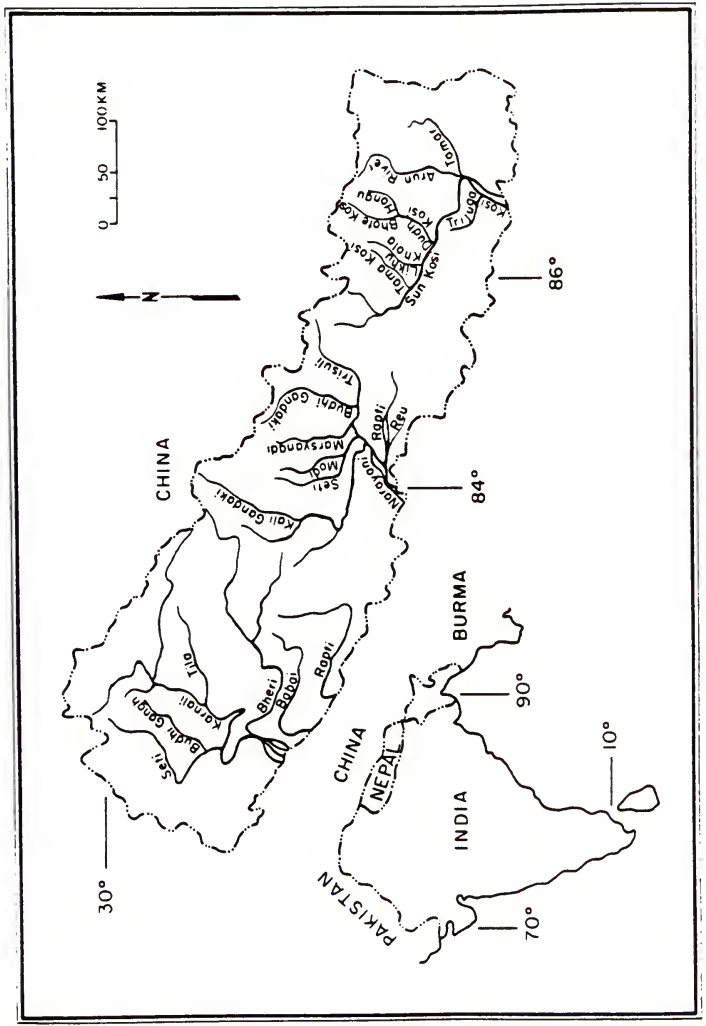

ב⿱ 


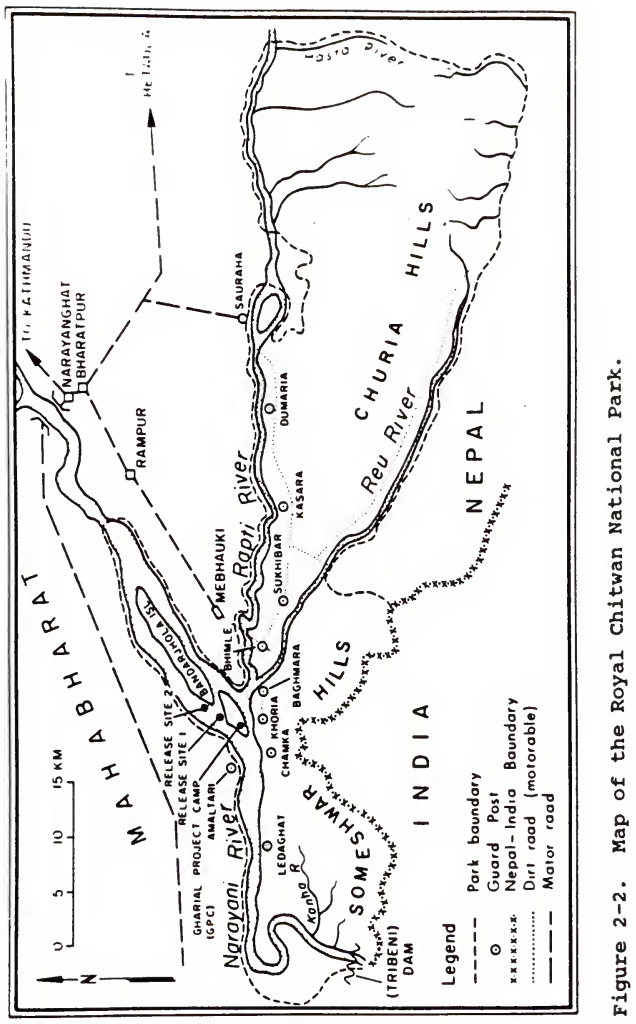


southernmost, the youngest (Oligocene-Pleistocene), and the lowest mountains $(815 \mathrm{~m})$ of the Himalayan system (Sharma 1984). The range passes through the middle of the RCNP and gradually drops to about $130 \mathrm{~m}$ near Sukhibhar, where it joins the combined flood plains of the Reu and Rapti rivers (Laurie 1978). The Shomeswar Hills, which have a maximum height of only $500 \mathrm{~m}$, are a complex mass of steep-sided ravines and sharp ridges that form the boundary between India and Nepal on the southwestern side of the Park. The Dawny Hills running southeast to northwest close the synclinal basin in the far west.

\section{Historical Background}

During the hundred years of Rana rule in Nepal prior to 1950, the Chitwan District was protected as a private hunting reserve exclusively for the use of the privileged classes and their guests. Until the 1950s, the valley contained over $2600 \mathrm{~km}^{2}$ of forest, swamp, and grassland that was famous for its wildlife and forest (Laurie 1978). Malaria was common in the valley, and it prevented settlement by people from the hills. The only human inhabitants of the area were the Tharu, an aboriginal tribe that lived in small openings of the jungle; the Tharu had developed some degree of resistance to malaria (Caughley 1969). 
During the cold winter months from December to February, the members of the Rana family, Nepal's hereditary Prime Ministers, held great hunts for the large animals such as the Bengal tiger (Panthera tigris) and one-horned rhinoceros (Rhinoceros unicornis). They invited royalty from India and Europe to take part in large-scale hunts employing 150-200 elephants (Elephas maximus) and 300-400 beaters to drive and encircle the game. A hunt, arranged in 1911 for King George V, produced a bag of 39 tigers, 18 rhinos and 4 sloth bears (Melursus ursinus). Another distinguished visitor to Chitwan in 1921 was the Prince of Wales, who bagged 17 tigers, 10 rhinos, 2 leopards (Panthera pardus) and 2 bears. A hunting party was arranged in 1938 for His Excellency the Viceroy, Lord Linlithgow, which lasted 68 days and the total bag included 120 tigers, 38 rhinos, 28 leopards, 15 bears, 11 crocodiles (including $\underline{G}$. gangeticus and $\underline{c}$. palustris), and one captured elephant (Smythies 1942). However, since the hunts were held irregularly in the different areas, poaching was controlled, and habitat destruction was minimal, animal populations probably did not suffer during that era.

Following the fall of the Rana in 1950, everything began to change in the Chitwan District. Big hunts were stopped, but agricultural development began. The hill people migrated into the Chitwan District because of problems associated with human population growth, overuse of 
available land, and catastrophic floods and erosion in the hills and mountains. They began clearing forests on an unprecedented scale. A malaria eradication program was launched by HMG Nepal and the United States Agency for International Development (USAID) in 1954 and, by 1960, the area was relatively malaria free. The entire length of the valley was settled by 1959 , coincident with the disappearance of $70 \%$ of the forest and grassland (Caughley 1969). According to estimates by USAID, the population in the Chitwan District rose from 36,000 in 1950 to 100,000 in 1960 (Laurie 1978). By 1970, the population of Chitwan Valley had increased tenfold (Sunquist and Sunquist 1988), and, at present, it is estimated at more than half million people. At the recommendation of E. P. Gee from the Fauna Preservation Society of London, HMG Nepal created a national park north of the Rapti River and a rhino sanctuary south of the river in 1961 (Bolton 1975).

A major step forward in the development of chitwan was the appointment, in 1963, of a government committee of inquiry to look into the legal status of chitwan settlers. This action was followed, in 1964, by creation of a land settlement commission, which was empowered to remove illegal squatters and resettle them in specially designated areas in the adjacent Rapti valley (Willan 1965). As a result, some 22,000 people were removed, including 4,000 who had settled in the rhino sanctuary. Grazing and the collection of 
forest products were still allowed within the sanctuary under permits issued by the Forest Department. In 1970, His Majesty the late King Mahendra approved the establishment of a national park to the south of the Rapti. Preliminary development of the park was started in 1971, and in 1973, the Royal Chitwan National Park was legally established. After the establishment of the RCNP, the DNPWC allowed people into the Park to harvest grass for a specified 15-day period, once a year. A permit system was imposed as a way of keeping a record of the number of grass cutters.

\section{Geology and Soil}

The Mahabharat Range is composed of hard rock, principally granite or quartzite, and limestone. The bedrock is late Tertiary Siwalik; it is characterized by the presence of large boulders carried from the north as outwash deposits. The Churia Hills also are composed of sedimentary rocks from the oligocene and Pleistocene, are endurated in some places and are loose and friable at other places, and are composed of mainly sandstones, conglomerates, shales, quartzite and micaceous sandstone (Laurie 1978, Sunquist 1979, Gurung 1983).

Although the Churia Hills lack water, there is a large diversity of flora and fauna in the area. The Churia Hills, because of deforestation and subsequent land slides, now 
contribute large sediment loads to the rivers of Nepal. The deep sandy loam and silt-loam soils of the floodplains consist of recent and alluvial sediment deposits from the north and are brown and grey in color.

\section{Climate}

The Chitwan District falls within sub-tropical latitudes and its climate can be divided broadly into 3 seasons: winter (October-February), summer (March-May) and the monsoon (June-September) season (Sunquist 1979, Gurung 1983). During the winter season the prevailing northwest and west winds result in greatly reduced temperatures (Shanker and Shrestha 1985). January, the coldest month, has average temperature ranging between $15^{\circ} \mathrm{C}$ and $28^{\circ} \mathrm{C}$ (Fig. 2-3). The nights are cold and damp with minimum temperatures ranging from $4^{\circ} \mathrm{C}-13^{\circ} \mathrm{C}$. The relative humidity approaches $100 \%$ (Fig. 2-4) at night with frequent heavy dew and ground fog, but average rainfall during the winter is only $3 \mathrm{~cm}$.

The summer season, which extends from March to late May is traditionally hot, but with low humidity (Fig. 2-3, 2-4). During summer, frequent local storms are produced as a result of extreme insolation and the orographic ascent of the air current over the southern slope of the Mahabharat 


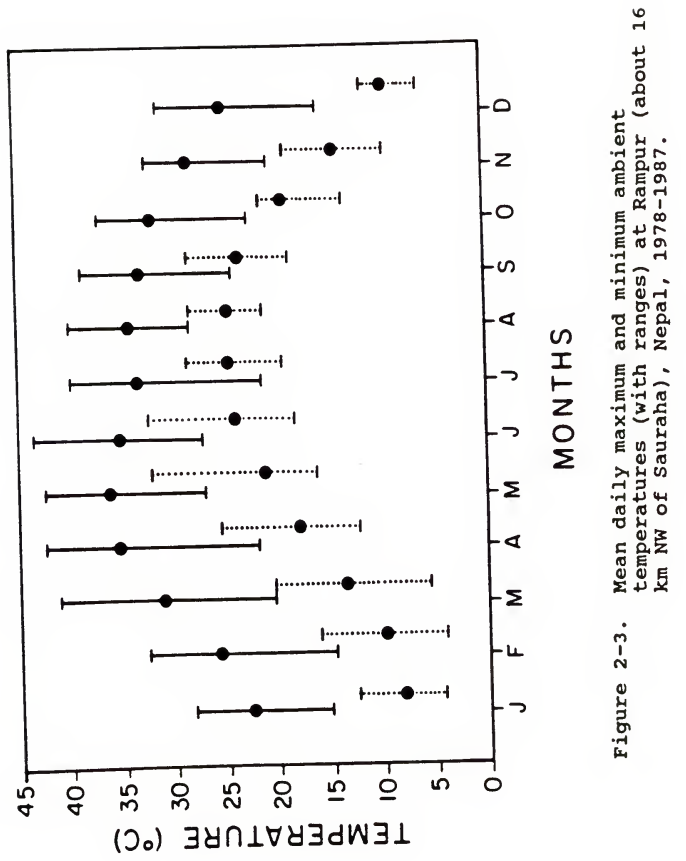




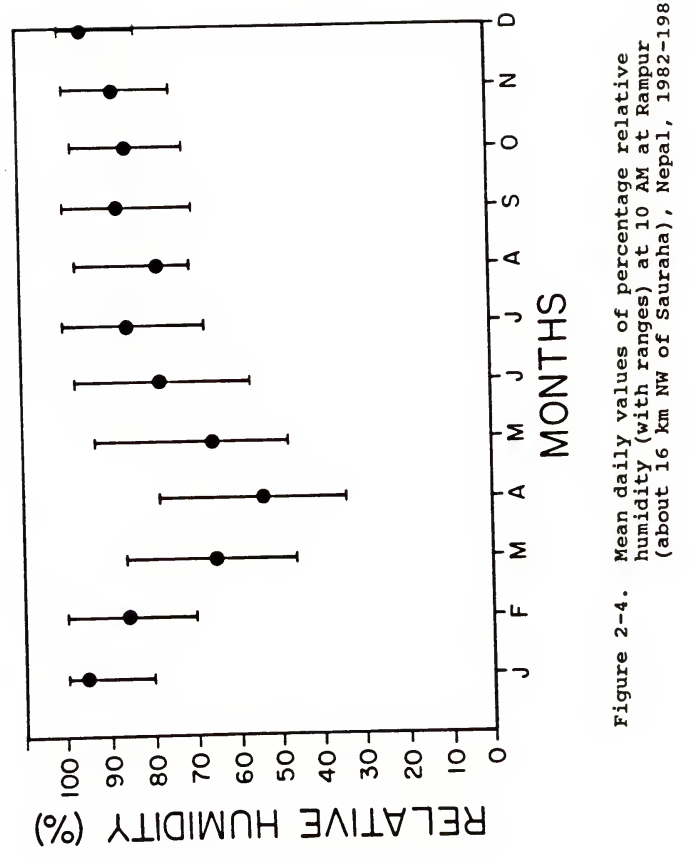




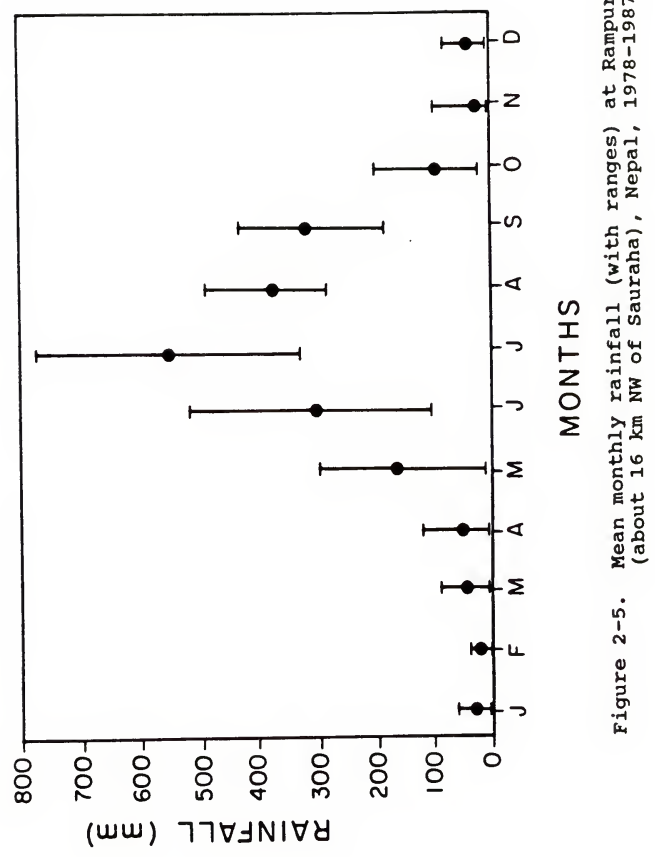


Range (Shankar and Shrestha 1985). During this pre-monsoon period, a prevailing southwest wind is often accompanied by thunderstorms and devastating sand and hailstorms. The temperature range in summer is $20^{\circ} \mathrm{C}-42^{\circ} \mathrm{C}$.

The frequency of afternoon rain increases in June and signals the start of the monsoon season, which extends from June through September. Frequent rainfall moderates temperature $\left(17^{\circ} \mathrm{C}-43^{\circ} \mathrm{C}\right)$ but adds to the high humidity. The maximum rainfall occurs in the month of July, with sporadic and scattered rainfall in August and September. The peak of the rainy season is comparatively short, but 70-90\% of the annual rainfall of $40-60 \mathrm{~cm}$ occurs during the period (Fig. $2-5)$.

There is wide variation in rainfall, temperature and humidity within the Chitwan valley (Laurie 1978, sunquist 1979). The wide variation in rainfall presumably arises from differences in juxtaposition to the hills, the river and the forest. Narayani River water temperatures are highest $\left(34^{\circ} \mathrm{C}\right)$ during the month of August and lowest $\left(13^{\circ} \mathrm{C}\right)$ during January (Fig. 2-6).

\section{Hydrology}

The Churia Hills are generally of low permeability. From the watershed of the Churia Ridge, numerous permanent and seasonal streams flow northward into the Rapti and 


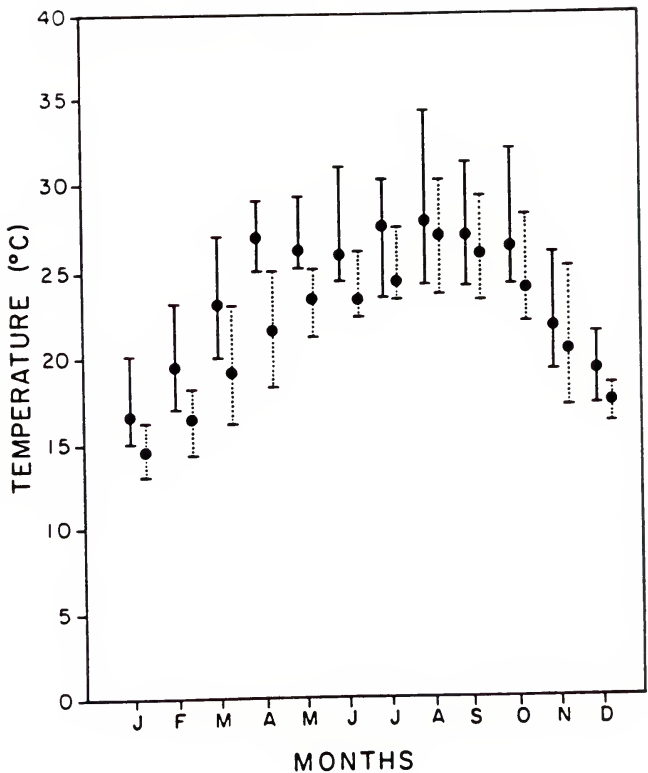

Figure 2-6. Mean maximum and minimum water temperatures (with ranges) in the Narayani River, 1987. 
southward into the Reu River. The RCNP area is drained by 3 main rivers--the Rapti, Narayani and Reu. The Rapti River originates in the Mahabharat Range at $2120 \mathrm{~m}$ near Chisapani Garhi (literally cold water fort), and flows southward and then westward from Hetauda for about $120 \mathrm{~km}$ to its confluence with the Reu and the Narayani river (Smythies 1941 and Shankar 1984). It is fed by ground water and springs, hence it does not dry up during the low-flow period.

The Reu River originates in the Churia Range and flows northwest for $35 \mathrm{~km}$ to its confluence with the Rapti. It is fed by the runoff water of the Churia Hills and is subject both to drying-up during low-flow seasons and to swelling unpredictably during monsoons.

The Narayani River is formed by the confluence of the Kali Gandaki and Trisuli rivers, which originate in the Himalayas. The Narayani flows southwest for $30 \mathrm{~km}$ from a gorge in the Mahabharat Range to the confluence with the Rapti. It then flows for $25 \mathrm{~km}$ along the base of the Someswar Hills (Fig. 2-7) in Nepal and eventually joins the Ganges River near Hajipur in India.

The Narayani River (including the Kali Gandaki and Trisuli rivers) drains an area of about $26,000 \mathrm{~km}^{2}$ in Central Nepal. The total length of this river is about 338 $\mathrm{km}$, and the average flow ranges between $1000-1700 \mathrm{~m}^{3} / \mathrm{sec}$. 


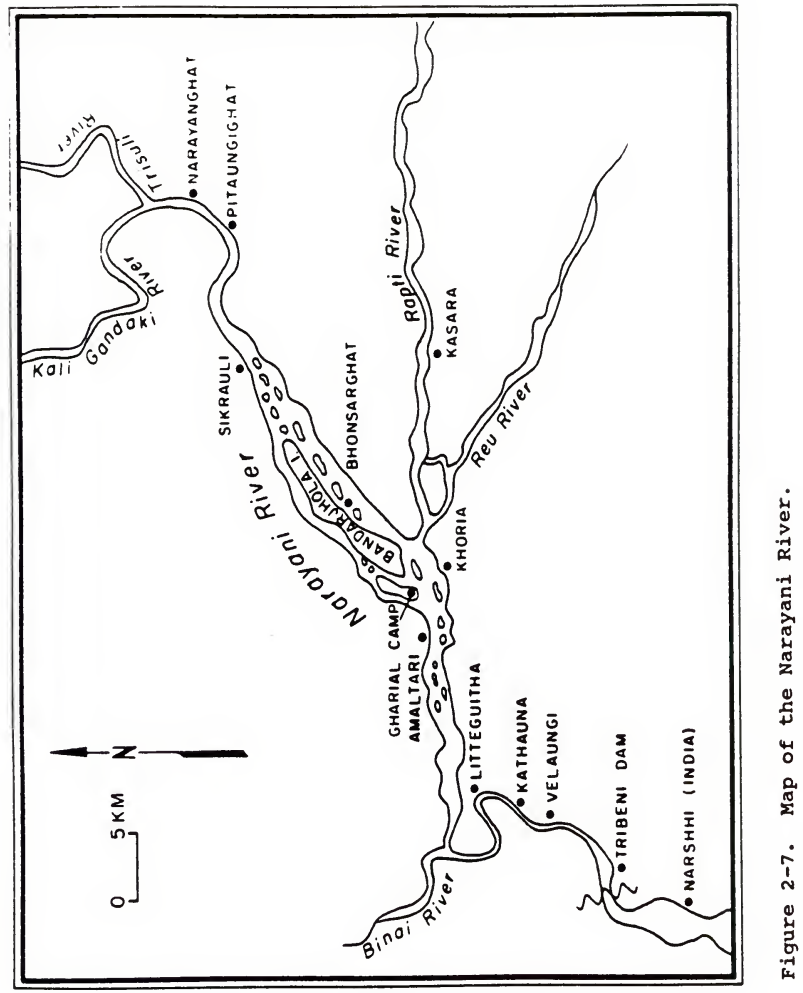


In the rainy season, the flow ranges from 10,000 to 700,000 $\mathrm{M}^{3}$ /sec (Panday 1987).

Drainage within the park is generally good; permanent standing water is confined almost entirely to small lakes or tals, which are found throughout the Park. During the monsoon season, the tall grass plains become water logged.

\section{Vegetation}

The Chitwan Valley is characterized by an immense expanse of tropical to sub-tropical forest. Bolton (1975) estimated that about $63 \%$ of the Park vegetation was predominantly sal (Shorea robusta) forest, a moist deciduous climax vegetation type of the terai region. The remaining vegetation types included grassland (19\%), riverine forest (6.5\%) and sal with pinus roxburghii (2\%), the latter occurring at the top of the Churia Range. Sunquist (1979) and Gurung (1983) classified the vegetation of RCNP into three main catagories: sal and hill forest; riverine forest; and grassland.

\section{$\underline{\text { Sal and Hill Forest }}$}

Sal is a climax type of vegetation that grows on the Siwalik Hills and other elevated sites. Sal commonly attains a height of 20-25 m, either in monotypic stands or with few associated tree species such as Terminalia spp., 
Anogeissus latifolia and Dillenia indica. A large number of other trees, shrubs, and creepers, such as Bauhinia valii, Spatholabus parviflorus, and grasses, such as Narenga porphyrocoma and Thrysia zea, grow under sal. In some areas of the Churia Range, Terminalia spp. dominates the sal (Stainton, 1972). Terminalia is associated with

Legerstroemia parviflora, Syzygium cumini, Adina cardifolia and pinus roxburghii.

\section{Riverine Forest}

Riverine forest occupies recently formed alluvial banks along the streams, lakes and rivers of the RCNP. Khair (Acacia catechu) and sissoo (Dalbergia sissoo) associations dominate the banks and islands of the Rapti and Narayani, particularly on recent alluvial deposits (Bolton 1975, Laurie 1978, Sunquist 1979, Dhungel 1984). Acacia catechu, a moderately large thorn tree also may occur on drier sites. Dalbergia sissoo, which may reach 20 meters in height, is almost entirely confined to the riverine situation. In the RCNP, the Acacia-Dalbergia ssociation, which may be very heavily dominated by one species or the other, usually is characterized by a dense undergrowth of pogostemon plectranthoides and a variety of other shade tolerant plants.

The Khair-Sissoo association is a colonizing vegetation type, that ultimately produces a condition more favorable to 
other species. An association of Bombax ceiba and Trewia nudiflora, with other species such as Butea monosperma, Bauhinia malabarica, Litsea monopetla, and Careya arborea, may represent later stages in riverine forest succession (Bolton 1975, Dhungel 1984). Callicarpa macrophyla and Emblica officinalis are common undergrowth shrubs in these situations. Another common tree, syzygium cumini, is an evergreen which often establishes monotypic stands.

\section{Grassland}

The alluvial floodplain occupies about $20 \%$ of the RCNP area and supports a luxuriant growth of grasses interspersed with patches of riverine forest. Laurie (1978) described 4 major types of grassland, each of which are in low-lying areas that are periodically inundated during the monsoon season (Sunquist 1979). Some creeping grasses such as Cynodon dactylon, Eragrostis japonica, Bracharia rimosa and Andropogon spp. are short-lived and grow seasonally on exposed silt banks as water levels decline.

Saccharum spontaneum, is the first species to colonize newly created sand banks, being replaced in succession by Saccharum munja, Erianthus ravennae and Narenga spp. Dense stands of Themeda villosa form a tall grass cover up to $6 \mathrm{~m}$ in height (Laurie 1978) in clearings in the sal forest and on old river courses. Arundo donax and Phragmitis karka, Saccharum ravennae, Typha elephantina and numerous species 
of tall cyperus grow on the floodplain and around lakes. In areas occupied by villagers prior to their evacuation in 1964, Imperata cylindrica (thatched grass) grows together with the taller Saccharum spp. (Willan 1965).

\section{Fauna}

Nepal lies in the zone of overlap between the southern Oriental fauna and northern Palearctic fauna (Laurie 1978, Dhungel 1984). The Chitwan forests are the home of the Bengal tiger, leopard, the sloth bear, the great one-horned rhinoceros, and gaur (Bos gaurus). The ungulates include the sambhar (Cervus unicolor), chital (Cervus axis), hog deer (Cervus porcinus) and barking deer (Muntiacus muntjak). Among the smaller animals in the park are the fishing cat (Felis viverrina), leopard cat (Felis bengalensis) and common jungle cats (Felis chaus). The large civet (Viverra zibetha), common palm civet (Paradoxurus hermaphroditus), large flying squirrel (Petaurista petaurista), and pangolin (Manis crossicaudata) add further variety. In 1978, a herd of 12 wild elephants was recorded (Maskey, RCNP monthly report 1979) in the southeastern part of the park. The forest historically supported wild buffalo (Bubalus bubalis) and swamp deer (Cervus duvaceli) (Smythies 1942) but they now are extinct in the area. A list of mammals of the Royal Chitwan National Park is provided as Appendix A. 
Among herpetofauna, two crocodiles, the mugger and gharial, are present in RCNP. In addition, Mitchell and zug (1986) recorded 10 species of frogs, 6 species of turtles, 7 species of lizards and 25 species of snakes. A checklist of amphibians and reptiles of RCNP is given as Appendix B.

About 440 species of birds have been recorded within RCNP (Dhungel 1984). The principal game birds are the peacock (Pavo cristatus), jungle fowl (Gallus gallus) and black partridge (Francolinus francolinus); migratory ducks and geese occur on the lakes and rivers of the chitwan District, particularly in winter. A wide variety of birds, representing 55 families, are found in the diverse habitat types of RCNP.

McGladdery et al. (1980) and Evans et al. (1985) recorded 58 and 69 species of fishes, respectively, from the rivers and lakes of RCNP. Later, Edds (1986) recorded 113 species of fish belonging to 10 orders and 23 families (Appendix C). The most common were Cyprinoides (61 species) and Siluroides (32 species). Many of the fishes of chitwan (e.g. the rohu (Labeo rohita), sahar (Tor putitora), jalkapur (Clopisoma garus), and raja bam (Anguilla bengalensis) are prized as food by human. otters (Lutra rspicillata), turtles, gharials, muggers, birds and many other wild animals of the park depend upon fish, principally Puntius, Apsidoparia and Barilius, in their diet (Edds 1986). 
STATUS OF THE WILD GHARIAL IN SOUTH ASIA

\section{Taxonomy}

The family Gavialidae, one of three families of crocodilians, is represented by only one genus with a single extant species, the gharial (Gavialis gangeticus). The gharial was first described by Gmelin (1789), who named it Lacerta gangetica, because Gmelin thought the gharial occurred in the Senegal region of Africa because he confused the gharial with the African slender-snouted crocodile, crocodylus cataphractus. In 1789, Bonnaterre renamed the species Crocodylus gavialis (Neill 1971). Opell used "gavialis" because Bonnaterre had used the same spelling in Crocodilus gavialis. However, Bonnaterre misspelled "gharials" as gavialis. The misspelling is the basis of the English common name and the gharial was subsequently placed in a separate family of its own, the Gavialidae (Neill 1971, Martin and Bellairs 1977). The English common name, gavial, arose because early European taxonomists were unfamiliar with the Indian word, gharial. 


\section{Geological origin and Phylogeny}

The geological history of the Gavialidae can be traced to the Pliocene in northern India (Lull 1944). Fossils of members of the family Gavialidae have been found in Tertiary deposits in Asia, North and South America, and Europe. Five Pliocene species were found in the low-lying Narmada hills of India (Smith 1931). One of the latter was almost indistinguishable from the living Gavialis gangeticus. Sill (1968) believed that the family Gavialidae may have arisen from the Hylaeochampsidae in the late Cretaceous. Subsequently, however, a different type of post-orbital bar, different shape and angle of the jaw articulation, as well as the long snout all suggest that the species has been separated from other crocodiles for a long period.

The phylogeny of the gharial is unclear owing to the fact that various members of the crocodilid sub-family Tomistominae have been described as gharials. Hecht and Malone (1972), who compared the early Tertiary longirostrine crocodiles with the living form, found that the fossils were related to only two genera, Tomistoma and Gavialis. Kalin (1955) and Langston (1965) separated gharials from Tomistoma on the basis of skull characteristics, finding that the comparatively large pterigoid bullae of Gavialis are the most distinct character among the crocodilians, but Densmore 
(1983) distinguished two genera by electrophoretic differences in phenotypes of blood protein.

In India, the true gharial was known from the early Miocene to the present (Lull 1944). Bauffetaut (1979) presumed that new world migrants arrived from Africa and Europe in the late Eocene when the ocean was narrower than it is now. Sill (1971) stated that the gharials are definitely Eusuchian and apparently arose from the basic crocodylid stock during the late cretaceous or early Tertiary, but Densmore (1983) suggested that both Tomistoma and Gavialis arose from Mesosuchian.

\section{Past and Present Distribution}

Historically, the gharial was abundant in all the large river systems of the Indian sub-continent (Figure 3-1). Its range extended throughout the Gangetic Plain, west to the Indus River in Pakistan, north and northeast to Nepal and Bhutan, east to Burma, and south to orissa in India (Neill 1971). The major river systems occupied by the gharial included the Indus in Pakistan; the Mahanadi, Chambal, Brahmani and Bhima of India; the Ganges and its tributaries of India, Nepal and Bangladesh (Neill 1971, Whitaker et al. 1974, Behura and Singh 1978) (Figure 3-1). Annadale (1915) stated that it once occurred in chilka lake, a large and shallow brakish water lake that lies south of Mahanadi River 
in India. It also was abundant in the Jamuna River in Utter Pradesh, India (Hornanday 1885) and the Kosi River (Shortt 1921). In Burma, it was recorded from the Maingtha River (a part of the Irrawady River and Kaladan River (Smith 1931). Barton (1927) recorded a specimen from the Shwali River system in Burma, although this record has been questioned by Whitaker and Basu (1983). It also was recorded from the Manas River (a tributary of Brahmaputra) in Bhutan (Bustard 1980a).

The gharial is now restricted to scattered, isolated populations in India, Nepal, Pakistan and Bangladesh (Behura and Singh 1978, Whitaker and Daniel 1978, Maskey 1984) (Figure 3-1). It inhabits portion of the Indus River in Pakistan, the Brahmaputra River in Bangladesh and India, the Ganges, Mahanadi and Chambal Rivers in India; and the Kali Gandaki, Narayani, Karnali and Babai Rivers in Nepal. It has been reported to be extinct in Burma (Behura and Singh 1978), the Kosi River in Nepal (Maskey 1984), and the Brahmani and Baitarani Rivers in India (Singh and Bustard 1982a). On February, 1985, Kar (1985) reported a gharial basking on Ghirmatha Coast, orissa, India. Although the gharial has been extirpated from the Brahmani and Baitarani rivers, Kar (1985) presumed that this population was established by gharial migrating from the Mahanadi River where wild gharials still occur. 


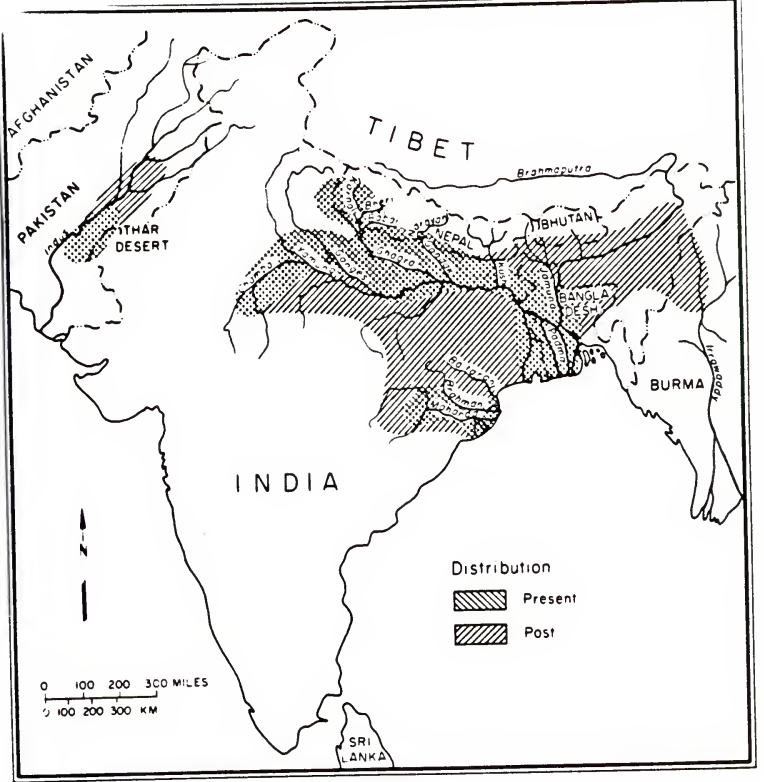

Figure 3-1. Past and present distribution of wild and released gharials in South Asia. 


\section{Population Status in South Asia}

Poaching and the loss and alteration of habitat had reduced the population of gharials in South Asia to an estimated 160 adult animals by the mid-1970s (Whitaker and Daniel 1978). Of these 160 gharials, 100 (62\%) were in India, 50 (31.5\%) in Nepal,7 (4\%) in Bangladesh and 3 (2\%) in Pakistan. The most current assessment of the wild gharial in South Asia yields a total population of $\leq 263$ adults and $\leq 215$ juveniles (Table 3-1).

In Bangladesh, Khan (1982a) reported that in the 1930s, gharials occurred in many of the small river systems (e.g., Mohanda, Punerbhaba, Modhumati, Tista and Bhairab rivers) as well as in the large rivers of the country such as the Padma, Jamuna, Meghna and Brahmaputra rivers. However, it now occurs in low numbers only in the Padma, Jamuna and Brahmaputra rivers. The Bangladesh population was reported at 20 in 1982 (Khan 1982b) and 28 in 1985 (Faizuddin 1985).

No sightings of the gharial have been recorded since 1977 in Bhutan, where it once occurred in the Manas River, a tributary of the Brahmaputra (Bustard 1979). Only one adult gharial was recorded in the Manas between 1962 and 1964. However, in 1977, an additional animal was captured and released back into the Manas River on the Bhutanese side of the Indo-Bhutanese border (Bustard 1980b). 
Table 3-1. The past and present status of wild and released gharials in South Asia.

\begin{tabular}{|c|c|c|c|c|c|}
\hline \multirow[b]{2}{*}{ Country } & \multirow[b]{2}{*}{ River } & \multicolumn{2}{|c|}{$\begin{array}{c}\text { Estimated wild } \\
\text { population }\end{array}$} & \multirow{2}{*}{$\begin{array}{l}\text { Captive } \\
\text { gharials } \\
\text { released }\end{array}$} & \multirow[b]{2}{*}{ Sources } \\
\hline & & Adult & $\overline{\text { Juvenile }}$ & & \\
\hline \multirow[t]{4}{*}{ Bangladesh } & Brahmaputra & 6 & 0 & 0 & Faizuddin \\
\hline & Jamuna & 4 & 0 & 0 & (1985) \\
\hline & Padma & 18 & 0 & 0 & \\
\hline & Subtotal & 28 & 0 & 0 & \\
\hline Bhutan & Manas & 0 & 0 & 0 & $\begin{array}{l}\text { Bustard } \\
(1980)\end{array}$ \\
\hline Burma & Irrawady & 0 & 0 & 0 & $\begin{array}{l}\text { Whitaker } \\
\text { and Daniel } \\
(1978)\end{array}$ \\
\hline \multirow[t]{8}{*}{ India } & Brahmaputra & 50 & 0 & 0 & \\
\hline & Chambal & 53 & 192 & 812 & singh et \\
\hline & Girwa & 9 & 19 & 85 & al. (1984) \\
\hline & Ken & 1 & 0 & 3 & \\
\hline & Mahanadi & 6 & 2 & 150 & \\
\hline & Ramganga & 4 & 0 & 12 & \\
\hline & Son & 18 & 0 & 2 & \\
\hline & Subtotal & 141 & 213 & 1064 & \\
\hline \multirow[t]{6}{*}{ Nepal } & Babai & 7 & 0 & 0 & Krishna $\mathrm{M}$. \\
\hline & Karnali & 7 & 2 & 0 & (per \\
\hline & Kosi & 0 & 0 & 84 & comm.) \\
\hline & Narayani & 58 & 0 & 223 & Maskey \\
\hline & Rapti & 2 & 0 & 0 & $(1984)^{2}$ \\
\hline & Subtotal & 74 & 2 & 307 & \\
\hline Pakistan & Indus & $<20$ & 0 & 0 & $\begin{array}{l}\text { Whitaker, } \\
\text { and Daniel } \\
(1978)\end{array}$ \\
\hline Total & & $<263$ & 215 & 1371 & \\
\hline
\end{tabular}


In Burma, the gharial is presumably extinct in the wild. In 1980, a survey party spent 26 days on the Kaladan River without sighting any gharial; furthermore, Burmese villagers indicated that gharials had been extinct in the river since about 1930 (Whitaker and Daniel 1978).

Gharials, once abundant in Pakistan, are now critically endangered (Bustard 1979, Whitaker and Basu 1983), with the population estimated at fewer than 20 animals (Whitaker and Daniel 1978). These gharials are restricted to the Indus River, around the Guddu barrage in sind and the Taunsa barrage in Punjab.

In 1973, Bustard (1974) estimated that between 60-70 wild gharials survived in various river systems of India. Later, in 1977 Whitaker and Daniel (1978) estimated the population at 100, and 1 year later, Singh, (1978) reported 2 males and 17 females in the Girwa River, 6 males and 12 females (plus 65 subadult and juveniles) in the Chambal River, and 2 males and 3 females in the Ramganga River. More recently, Singh et al. (1984) reported 141 adult and 213 juvenile gharials in India. By 1984, India had released 1,064 captive-raised gharials in various areas, which has potentially increased their population of wild gharial to at least 1,418 .

The wild gharial had been depleted in India to the stage of extinction by the early 1970s, being declared an endangered species in 1972 (Wildlife Protection Act 1972). 
In the past decade, however, the gharial population has improved because of conservation measures implemented in several states. Recovery has been achieved by total legal protection of the species, accompanied by the creation of special gharial sanctuaries under provisions of the wildlife Protection Act, 1972 (Singh 1986).

In Nepal, gharials were once widely distributed in all major river systems of the country. The ranges included the Karnali, Babai and Rapti rivers in western Nepal, the Kali Gandaki and Narayani rivers in central Nepal and the Kosi River in eastern Nepal. Currently, the species is found only in isolated populations in the Karnali, Babai, Kali and Narayani rivers. Efforts to locate wild gharials in the Kosi and Rapti rivers during the early 1980's failed to yield the presence of any wild animals (Maskey 1984). 


CHAPTER IV
POPULATION STATUS OF THE WILD GHARIAL IN NEPAL

\section{Introduction}

Until the early 1960s, gharials were found in all the major river systems of Nepal, including the Karnali, Babai, and Rapti rivers in western Nepal, the Kali Gandaki and Narayani rivers in central Nepal and the Kosi River in eastern Nepal (Fig. 4-1). By the late 1970s, there had been a drastic depletion in their abundance and distribution; in fact, the gharial had become extinct in the Kosi River in eastern Nepal. The gharial population in Nepal would probably be on the verge of extinction were it not for the present gharial conservation program. A variety of causes contributed to the large scale destruction of the gharial population: habitat loss and disturbances; lack of strict enforcement of existing laws; killing animals for the hide; accidental drowning in fish nets; construction of reservoirs and dams; and removal of eggs by local people for use as food. Gharials in Nepal are fully protected under the Wildlife Protection Act, 1973, and are listed as "endangered species" in the IUCN Red Data Book (1975). 


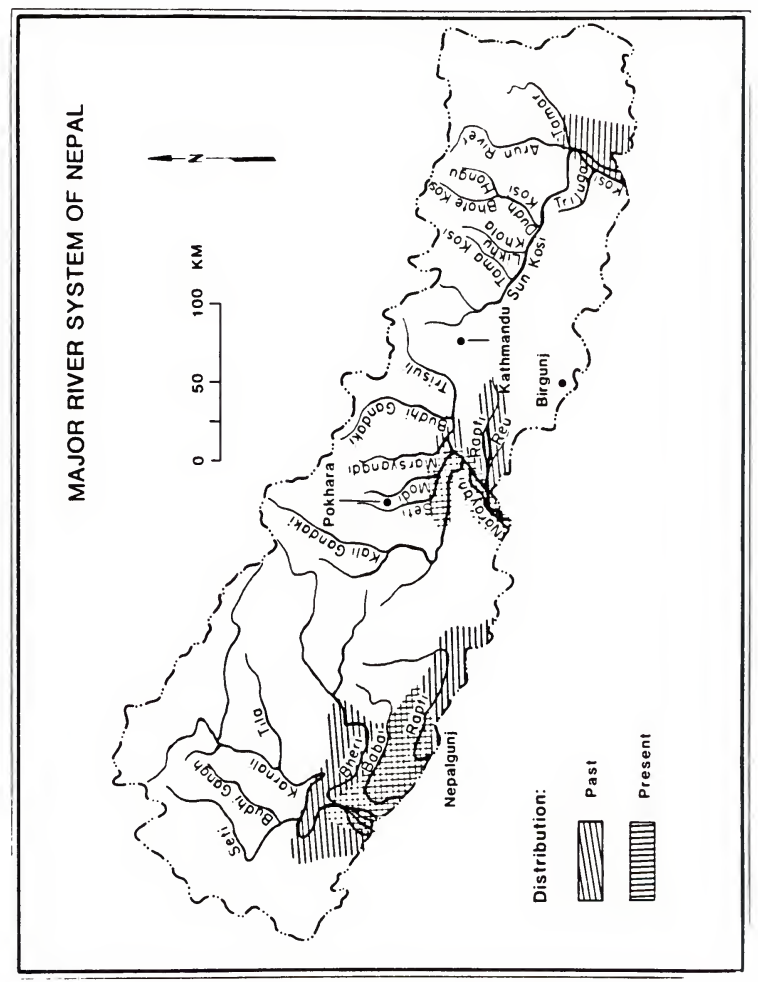

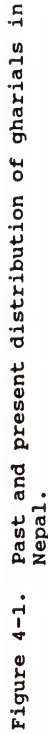




\section{Methods}

A survey of gharials was conducted in the Narayani and Kali Gandaki rivers during 1983, 1984, 1986 and 1987. The Narayani and Kali rivers were divided into five sectors: sector 1--the Kali River (KALI); sector 2--the portion of the Narayani between Narayanghat and Sikrauli (NASI); sector 3--the portion between Sikrauli and Khoria, which includes both the northern and southern major channels of the Narayani River (SIKH); sector 4--the portion of the Narayani from Khoria to Materi (KHMA); and sector 5--the portion from Materi to Tribeni (MATB) (Figure 4-2).

The survey from four dugout canoes by a team consisting of two observers (research assistants) and eight boatmen, who were members of the local ethnic culture, the Bote. The main livelihood of the Bote is derived from fishing in the Narayani River, and, consequently, they are very familiar with the habits and natural history of the gharial. During the 1987 study period, the entire length of the Kali Gandaki and the Narayani were surveyed once each month. Surveys were conducted between $0900 \mathrm{hrs}$ and $1600 \mathrm{hrs}$. Each survey required 10 days to complete. During each survey, the estimated size, sex, and location of sighted animals were recorded. Observers used $7 \times 50$ binoculars to observe 


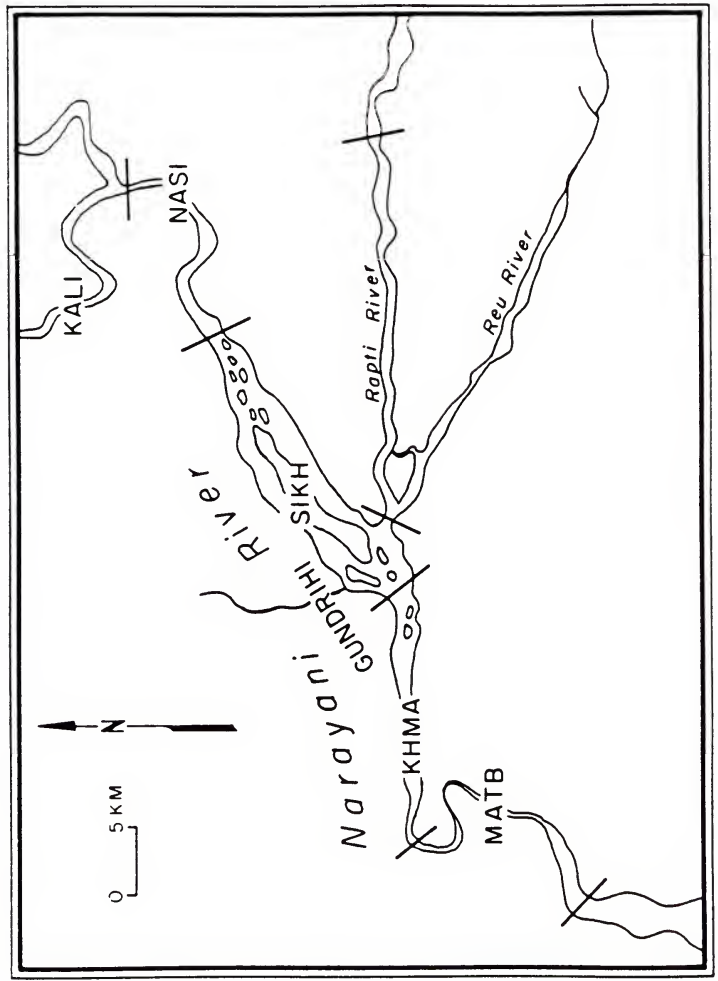

告 is 4 . $0>1$ ᄃ리 सै है 刃 - 5 o $\rightarrow \infty$ ดे न्म 草 
gharials. The monthly census stastic was derived from the total number of animals seen per census, i.e., the sum of daily (census segment) counts.

\section{Population Status in Nepal}

Before 1960, gharials were most abundant in the Narayani River (Jung Prasad, pers. comm.) and its largest tributary, the Rapti River, in the Chitwan Valley of southcentral Nepal. The Rapti flows for $120 \mathrm{~km}$, from east to west along the Chitwan valley floor, prior to joining the Narayani. The Narayani, Nepal's third largest river, flows through a relatively low gradient and is fed principally by 2 major rivers, the Kali and the Trisuli, which originate in the Himalayan region. The Narayani River has a maximum width of a kilometer and consists of a large number of channels and islands. It swells to a maximum level during the monsoons of June-September, and carries a high sediment load. During the dry season (December-March), the river recedes to the center of the flood plain, and is fed by snow-melt water from the Himalayas. The river is flanked by open sand banks, rocks, and stands of phragmites (Phragmites karka) and other grasses.

The Mugu Karnali River, originating in the Ladakh Himal, joins the Humla Karnali, which originates in China (Tibet), giving rise to the Karnali River (Fig. 4-1). The 
Karnali, which flows for $507 \mathrm{~km}$, is characterized by many gorges. One of the areas that provided habitat for gharials was the Chisapani Gorge, which lies in the Karnali Wildlife Reserve in western Nepal. This habitat was severely degraded by the construction of a bridge over the Karnali River at the Chisapani Gorge in 1975. The gharial population on the Karnali, which numbered 15-20 adult gharials in the mid-1970s, currently (1988) is estimated at 7 animals (Krishna Man, pers. comm.).

Hundreds of gharials were observed on the lower Narayani River prior to the construction of the dam on the river near the Indo-Nepalese border in 1964 (pers. comm. with local people). In the early 1950s, about 235 gharials occurred along the river between Narayanghat and Tribeni (Juthe Ram pers. comm.). These gharials were concentrated mainly near sites, e.g., Litteguintha, Kathauna, Velaungi, Narsahi, Khoria and Pitaungighat, that exibited deep water and prevalent sand banks (Fig. 2-7). Also in the early 1950s, there were 40-50 gharials near the border of Nepal and India (States of Bihar and Utter Pradesh); these gharials had been extirpated by Indian poachers by 1960 (Jung Prasad and Thare Mukhia pers. comm.).

Approximately 76 wild gharials were extant in Nepal in 1988 (Table 3-1). This population represents $16 \%$ of the world population. The largest single population, consisting of about 60 adults, was found on the Narayani River (Table 
3-1, Fig. 4-3). In March 1977, Sharma (1977) reported a population of 58 wild gharials on the Kali and Narayani rivers (Fig. 4-3). Surveys between 1980 and 1987 revealed 51-60 wild gharials in the Kali and Narayani rivers (Fig. 43). Additionally, 307 captive-reared gharials have been released in the Narayani, Kali, Kosi, and Rapti rivers of Nepal since 1981 .

Surveys of the Karnali River detected 10 gharials in both 1978 and 1979 (Bhim Gurung, pers. comm.), and 9 gharials in 1986 (Krishna Man, pers. comm.). In 1987, Krishna Man, (Warden, Karnali Wildlife Reserve) reported the occurrence of seven gharials in the Babai River, and three (or less) gharials in the Rapti River of western Nepal.

In the Narayani, the population is most concentrated (1.1 animals per $\mathrm{km}$ ) in the Sikrauli-Khoria (SIKH), and Materi-Tribeni (MATB) sectors ( 0.9 animals per km) (Fig. 45). This area of the river is dissected by numerous river channels that provide suitable habitat for basking, feeding and nesting. Furthermore, the MATB sector flows through a gorge, both sides of which are included inside RCNP, thereby offering additional protection from human disturbance. The Narayanghat-Sikrauli (NASI) ( 0.1 animal per $\mathrm{km}$ ) and KhoriaMateri (KHMA) (0.8 animal per $\mathrm{km}$ ) sectors are more subject to human disturbance. The population of gharials in the Kali River ( 0.5 animal per $\mathrm{km}$ ), which includes 3 males and 8 

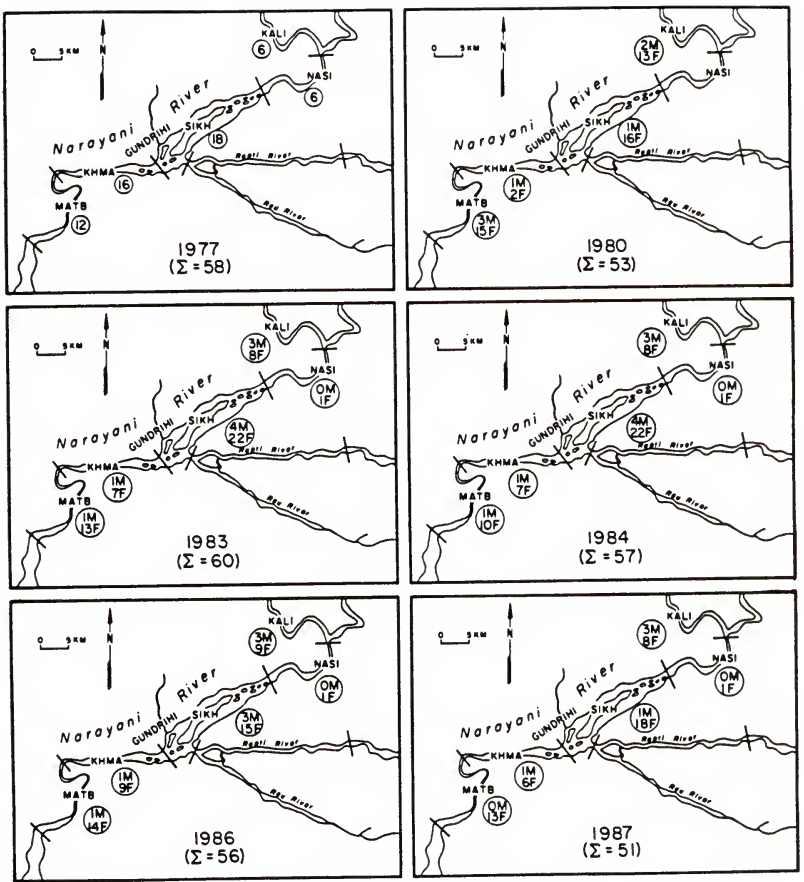

Figure 4-3. Status of wild gharial in the Narayani and Kali rivers, Nepal in 1977 (Sharma 1977) and in $1980,1983,1984,1986$, and 1987 (this study). Number of adult gharials by sex are denoted (within circles) by sectors of the rivers (see Fig. 4-2). The total number of gharials surveyed by year is denoted by $\Sigma$. 


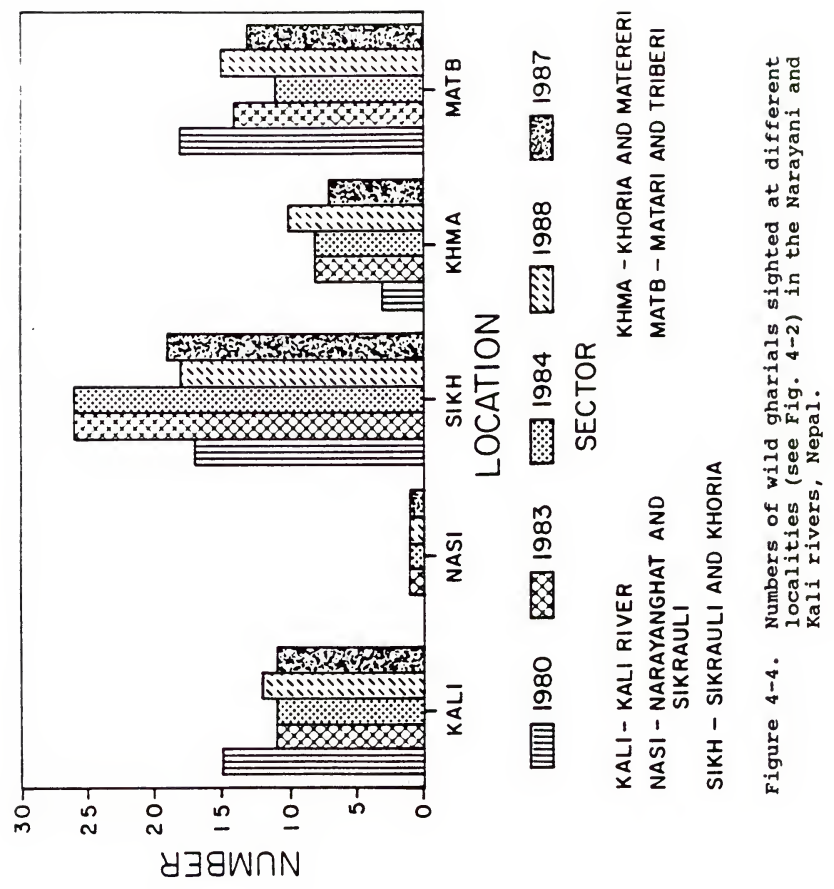


females, is in jeopardy because the area is without the protection afforded by the RCNP. Gharials use the Rapti and Gundrihi rivers only during monsoon fllods.

The visually observed sex ratio of the gharial in Nepal, which strongly favors females, represents a problem of paramount concern. The highest sex ratio of the gharial 1 male to 6 females was recorded in 1984 (Fig. 4-5), whereas the lowest ratio of 1 male to 9 females was recorded in 1987. The low number of males can be attributed directly to (a) heavy poaching of the male in the past for the "ghara" and, (b) temperature effects on incubation/hatching in the hatchery. Because earlier superstitious beliefs about the ghara have diminished, modern poaching may not be as selective. In the future, the number of male gharial might be increased by releasing more captive-reared male gharials; however, that strategy does not lessen the severity of the current situation.

\section{Factors Responsible for the Decline of Gharials}

Although poaching may have been responsible for the disparate sex ratio, the major cause of the critically depleted population of the gharial is largely attributable to the construction of dams for hydroelectric power and irrigation. These dams create abnormally high water during 


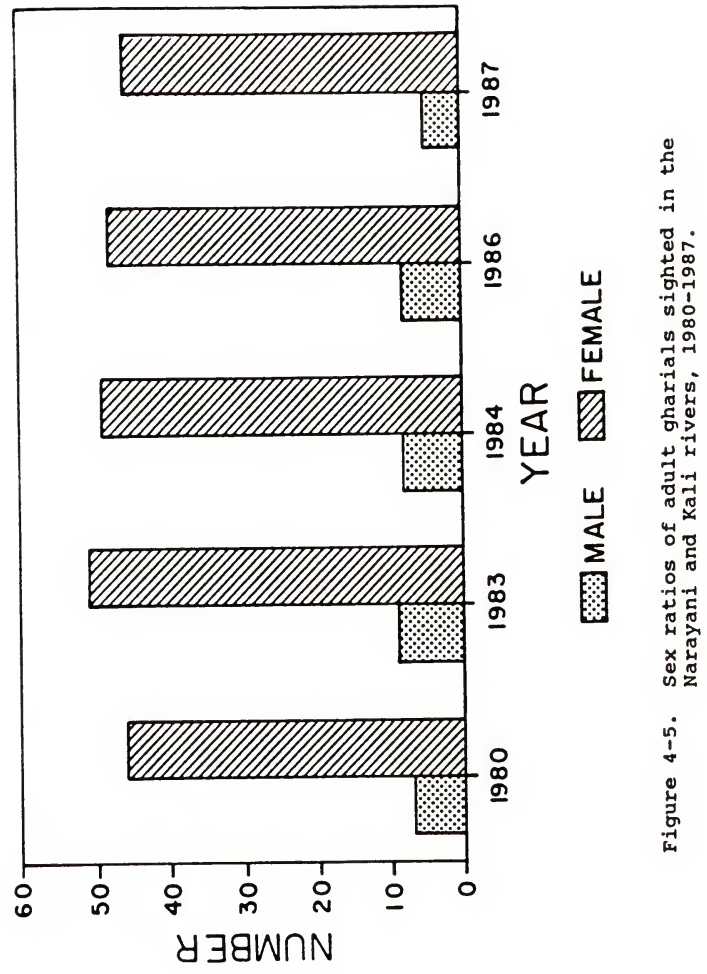


the monsoon which floods practically all nests near the dam. Also the dam allows only one way movement of gharials; any movement downstream of the dam eliminates the individual from the Nepal population. Secondary causes are commercial fishing activities and the poaching of both large animals and eggs.

The preferred riverine habitat of gharials (deep, fast flowing water and high sand banks) also coincides with those riverine features favorable to the construction of dams (Singh 1978). Habitats also are affected by channelization and bulkheading to prevent flooding. To illustrate, prior to 1975, the Karnali River, supported a good population of gharials at the Chisapani Gorge. At present, the population is severely reduced because bridge construction ruined a prefered basking site. Singh (1986) reported that the gharial population in the Girwa River increased from 14 to 25 within a year (1976). The sudden increase in the Girwa population is attributed to migrant gharials that had been displaced by disturbance at the bridge construction at the Chisapani Gorge. Bridge construction not only required heavy blasting and physical habitat alteration but increased both temporary and permanent human use of that stretch of the river. In addition, there is also a stone quarry at Kothiaghat, about $10 \mathrm{~km}$ downstream from Chisapani, where the daily use of 70-80 boats to transport about 500 workers creates a perpetual disturbance to gharials. Consequently, gharials from the Karnali have been driven to India, and 
have not returned. No breeding is now known in the area (Krishna Man, pers. comm.).

Another cause of the population decline in the Narayani and Karnali rivers is due to the unsuccessful hatching from natural nests. Gharials start laying eggs from late March and early April and the water rises in April. In the case of the Chisapani area, the water level swells immediately after winter (March) from snow melt in the Himalayan region. Due to the presence of the gorge at Chisapani, the water level rises $1.5-1.8 \mathrm{~m}$ above the normal level and most of the nests from that area are washed away during flooding. However, there are some areas below the Chisapani Gorge where nesting is safer from flooding. In the Narayani River, there are some flooded plains and channels where gharial eggs are protected from flooding. But occasionally they are washed away either by early monsoon floods or by the rising water from the snow melt. Most of the nests from Bhimband, Kathauna and Velaungi (Fig. 4-2) are flooded before hatching. Gharials have adapted partially to the changing water regime by nesting on very high sand banks in these areas. The high water level during monsoons also causes extensive erosion of gharial nesting habitat. The natural process of soil erosion and increased runoff has been augmented by human pursuit of more food, collecting more fibre, fodders, fuel and other concumptive needs in the hill region. Ecological degradation and 
devastating floods have affected the gharial habitat in the major river systems of Nepal. Each year 240 million $\mathrm{M}^{3}$ of soil are carried by Nepal's major river systems.

The use of large seines (called Mahajal) and gill nets in the major rivers of Nepal not only have reduced the fish population but caused direct mortality to gharials. The local fishermen kill the gharial to protect their expensive nets from being extensive damage. The combined effects of dam construction and fishery exploitation have weighed heavily against the survival of the gharial. However, large scale commercial fishing in the Narayani River was prohibited in 1973, after the establishment of the Royal Chitwan National Park.

Before 1950, Chitwan was well known for a variety of wild game and was preserved as a Royal hunting reserve (Smythies 1942). Annual winter hunts, would result in kills of about 50 gharials annually (Jung Prasad, pers. comm.) or normally about 4 gharials per day (Nathu Ram, pers. comm.). Some of the gharials also were killed by high-ranking Government officers in the area. For example, it was reported that a police chief killed 16 gharials at one time and a circle officer for the district killed around 50 gharials during his service period (Jung Prasad pers. comm.). Most of the gharial hides were sold in India for Rs. 250-400 (U.S. \$12-20) each. 
Gharial eggs were believed to have medicinal value in parts of India and Nepal. In Nepal, the local Tharu people believed that the gharials eggs had aphrodisiacal and medicinal value. For example, the dry powder of the egg is considered to be effective as a cough medicine. Because the eggs do not taste good, they were mixed with flour and prepared as bread (Bika Ram and Natthu Ram, pers. comm,). Eggs were sold for Rs. 30-40 (U.S. $\$ 1.50-2.00$ ) on both sides of the Nepali-Indian border.

Since the gharial population has continued to decline, conservation measures are neccessary to protect the surviving population. Fewer than $1 \%$ of all gharials hatched in nature reach a length of $2 \mathrm{~m}$, a length at which they are generally secure from natural predation (Singh 1978). One breeding female may lay from 14-62 eggs (see Chapter $V$ ) in a clutch, but the eggs generally fall victim to predators, to poachers, and, particularly to flooding. The objectives of the Chitwan rehabilitation project are to protect nest sites, to carefully collect and incubate wild eggs, and to rear hatchlings to a length of $2 \mathrm{~m}$ for restocking the Narayani River. It is recommended that the existing rehabilitation program in the chitwan be expanded to the Karnali and Babai rivers. More gharials should be released and monitored in the Kosi and Karnali rivers to evaluate the efficacy of that program there. Another protective measure 
50

to be considered is creation of reserves and sanctuaries to protect existing and future breeding populations. 


\section{CHAPTER V \\ HABITAT SURVEY AND STATUS OF GHARIAL \\ IN ROYAL CHITWAN NATIONAL PARK}

\section{Introduction}

Over the past two decades there has been a drastic depletion of the gharial population of Nepal. The situation had become so alarming that the gharial was listed as endangered in 1972 (Bustard 1975, Whitaker and Daniel 1978, Groombridge 1982) and drastic actions have been taken to repopulate the species in both India (Singh 1986) and Nepal (Maskey 1984). The main factors contributing to the decline are habitat loss and disturbances caused by increased human populations within the river drainages.

Restocking is a conservation measure that is often implemented in seriously depleted stocks (Bustard 1984) and has been discussed by Chabreck (1971), Pooley (1971, 1973), Nichols et al. (1976), and Choudhury and Bustard (1981). A restocking program was implemented in the Narayani River to protect the last stronghold of the species in Nepal. Because of its remoteness and lack of scientific attention, little was known about the species and its habitat requirements in Nepal. Therefore, the main objectives of this study were: a) to survey the gharial population in the 
Narayani River, b) to evaluate habitat use, and c) to define the seasonal distribution pattern of breeding females. The study was designed to provide the basic scientific information needed by HMG Nepal to develop and implement an effective conservation program for the gharial.

\section{Study Area}

The study was conducted in the Narayani River of the RCNP in the southwestern part of the Chitwan District, which lies at approximately longitude $84^{\circ} 20^{\prime} \mathrm{E}$ and latitude $27^{\circ} 30^{\prime}$. . (Chapter II, Fig. 2-1). The Rapti River forms the northern boundary of the Park and the Reu River forms a large part of the southern boundary (Chapter II, Fig. 2-2). The western boundary follows the Narayani River including a narrow extension to the park extending $18 \mathrm{~km}$ to the northeast and encompassing a number of forested islands, the largest of which is Bandarjhola. The eastern boundary crosses the Churia Hills from Hasta Khola on the Rapti to the Shikaribas. The altitude of the flood plain varies from 120 to $815 \mathrm{~m}$. The Churia Hills are generally of low permeability, and, consequently, numerous permanent and seasonal streams flow northward into the Rapti and southward 
into the Reu Rivers (see Chapter II for detailed description of the RCNP and the Narayani River in Chitwan District).

The Chitwan District's sub-tropical climate is divided broadly into three seasons: winter, summer and monsoon (Sunquist 1979, Gurung 1983). January, the coldest month, has an average temperature of $25^{\circ} \mathrm{C}$ ranging between $4^{\circ} \mathrm{C}$ and $28^{\circ} \mathrm{C}$. The relative humidity approaches $100 \%$ at night with frequent heavy dew and ground fog but average rainfall during the winter is only $3 \mathrm{~cm}$. The temperature range in summer is $20^{\circ} \mathrm{C}$ (minimum) to $42^{\circ} \mathrm{C}$ (maximum). Maximum rainfall occurs in July with sporadic and scattered rainfall occurring in August and September (see Chapter II for detailed description).

\section{Methods}

A standardized survey of wild gharial was conducted from 1983-1987 in the Narayani and Kali rivers. The river system was divided into five survey sectors: a) the Kali River (KALI); b) the section of the Narayani River between Narayanghat and Sikrauli (NASI); c) the section of the Narayani between Sikrauli and Khoria, including both the north and south channels (SIKH); d) the section between Khoria to Materi (KHMA); and e) the section between Materi to Tribenighat (MATB) (Fig. 5-1). The survey was conducted from dugout canoes by two teams, each consisting of a 
trained observer and four boatmen. The boatmen were members of the local tribe, the Bote, who derive their livelihood from fishing.

The survey was conducted once during December and May in 1983, 1984 and 1986, but monthly in 1987. The route for all surveys began at the Gharial Project camp (GPC) (Fig. 51) on the Narayani River and headed northeast following the northern channel of the SIKH sector. The KALI sector was surveyed upstream from the confluence of Kali Gandaki and the Trisuli rivers. The NASI, southern channel of the SIKH, KHMA, and MATB were surveyed downstream from the KaliTrisuli confluence to the Tribeni Dam. Surveys were conducted between $0900 \mathrm{hrs}$ and $1600 \mathrm{hrs}$. Each survey required 10 days to complete. During each survey the estimated size, sex and location of sighted animals were recorded. The wild and released gharials were separated on the basis of their size and scute marks on the tail. All of the released gharials were less than $3 \mathrm{~m}$ in length, and most had some sort of markings on the tail. The gharials released in 1981 had a scute removed from the tail (Fig. 52a), those released in 1982 had a big hole at the base of the tail scute (Fig. 5-2b), and those released in 1987 had a distinct yellow plastic tag attached to the tail scute (Fig. 5-2c). Gharials released in 1983 and 1984 were not marked. 


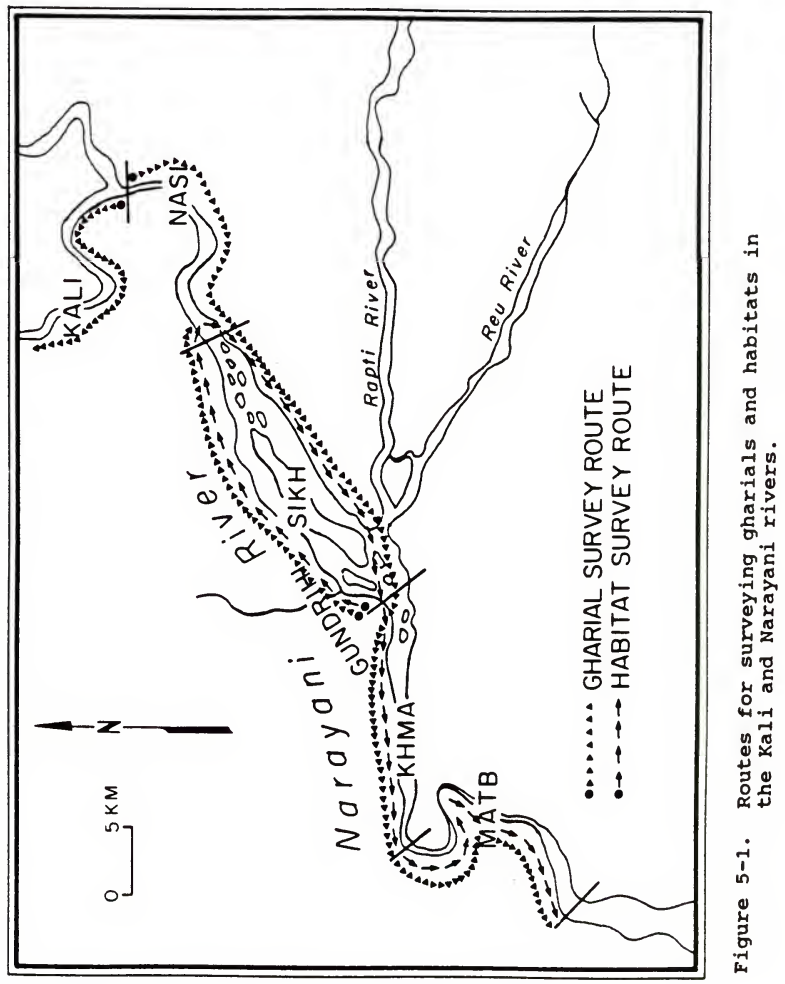


During the monsoon, gharials have used the major tributaries of the Narayani River. Thus, counts were made in the Rapti and Gundri Rivers during the monsoon. These counts were not added to total population counts because these animals would have been in the main channel when water receded after the monsoon.

Two habitat surveys were conducted, during June 1987 and January 1988, to determine the proportion of different habitats available for gharial-use during pre- and postmonsoon periods. Habitats were classified into five categories: sand banks (SB), grass banks (GB), sand-grass banks (SGB), rocky banks (RB), and river channel (RC). Sand banks were high banks of fine sand that lacked vegetation. Grass banks principally were composed of sand with a vegetative cover of grasses. During the dry months, various short grasses and herbs (e.g, polygonum plebujum, Persicaria spp. Cyperus spp.) grew on exposed sand banks. Sand-grass banks were those having more sparsely distributed Saccharum spp. and other grasses. Rocky banks consisted mainly of stones ranging from $50 \mathrm{~mm}$ to $250 \mathrm{~mm}$ in diameter. River channels are the permanent flooded waterways within the river banks. Habitat surveys were made of only the SIKH, KHMA and MATB sectors. All areas were not included in habitat survey because of extreme logistics required to survey the area. All percentage of each habitat type available on both sides of the river within $200 \mathrm{~m}$ long 


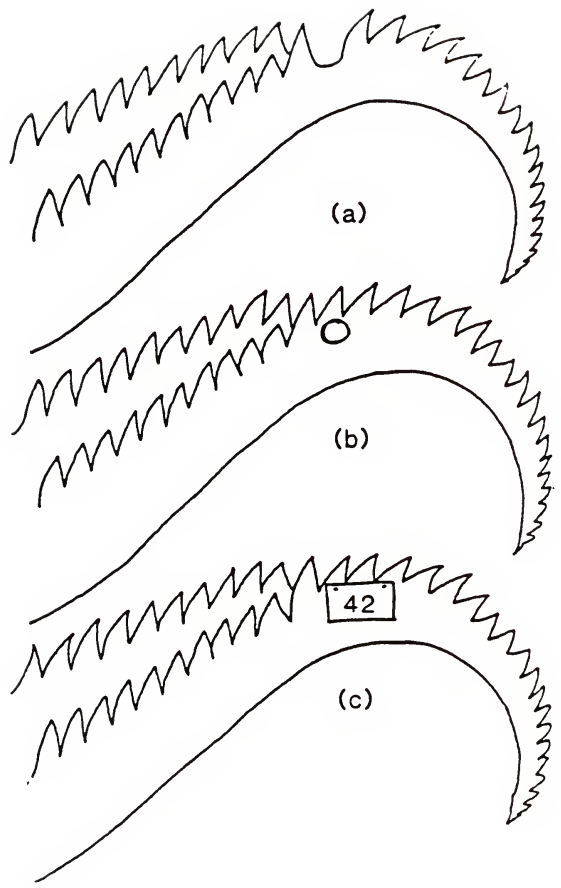

Figure 5-2 Gharial tail, showing the marking pattern used to identify released animals: (a) 1981 release, (scute removal); (b) 1982 release (hole under scute; and (c) 1987 release (plastic tag). 
sectors were recorded. The proportion of each available habitat was calculated by summing the percentage of each habitat recorded on both sides of the river within the $200 \mathrm{~m}$ sectors.

\section{Results}

Minimum population estimates of $60,57,56$ and 51 wild gharials were calculated from 1983, 1984, 1986, and 1987 surveys, respectively, in the Narayani and Kali rivers (Table 5-1). The gharial population was not evenly distributed among the five sectors of the river. Densities of animals were unevenly distributed among sectors: 0.8 animals $/ \mathrm{km}$ in MATB, 0.5 animals $/ \mathrm{km}$ in KALI, 0.4 animals $/ \mathrm{km}$ in SIKH, and KHMA, but only 0.1 animals/km in NASI. The minimum population of 51 gharials within each sector was 19 in SIKH, 13 in MATB, 11 in KALI, 7 in KHMA, and 1 in NASI.

similarly, a minimum population estimate of the released gharials calculated from 1983, 1984, 1986, and 1987 surveys was not evenly distributed. Most of them were located in the SIKH sector of the Narayani River. The combined densities of the wild and released gharials were fairly even across three sectors: 1.1 animals/km in SIKH, 0.9 animals/km in MATB, 0.8 animals/ km in KHMA. The combined minimum population of wild and released gharials within the sectors based on December surveys, were 50 in 
SIKH, 16 in KHMA and 15 in MATB (Table 5-2). December survey in the Kali and Narayani rivers yielded higher counts because of low water conditions. Therefore, they were considered the most reliable as minimum population estimates.

During the monsoon season, wild gharials enter tributaries to avoid the increased force of waterflow in the Narayani River. A maximum of five wild gharials were counted in the Rapti River at Sauraha, which lies about 50 $\mathrm{km}$ upstream of the Rapti-Narayani confluence. Also, three of five young gharials that escaped from captivity into the Rapti River in 1986 were observed regularly near Dudhaura in the Rapti River.

The habitat survey which measured proportional linear distances along the river indicated that rocky banks constituted the most available habitat in the Narayani River both in June and January respectively (Table 5-3).

Gharials used all five habitat types (Table 5-4) but they were not observed on rock, grass, or sand-grass banks in proportion to their occurrence. There was a significant difference in habitat selection by adult gharials ( $F=$ 266.44, df $=4,56 ; \mathrm{p}<.05)$. Because of the disparate sex ratio of 1 male to 9 females in the wild population, independence in habitat use between the sexes could not be demonstrated (Chi-square $=2.59$, df $=2, p=0.27$ ) . Therefore, sexes were combined in this analysis. Gharials 
Table 5-1. Surveys of gharials in five sectors of the Narayani and Kali rivers in 1983, 1984, 1986 and 1987 .

Numbers sighted by sector

$\begin{array}{llllll} & & & & & \\ \text { Year } & \text { KALI } & \text { NASI } & \text { SIKH } & \text { KHMA } & \text { MATB }\end{array}$

\begin{tabular}{|c|c|c|c|c|c|c|c|c|c|c|c|c|}
\hline 1983 & 11 & $(11)^{a}$ & 1 & $(0)$ & 26 & (19) & 8 & (1) & 14 & $(07)$ & 60 & (38) \\
\hline 1984 & 11 & (11) & 1 & (1) & 26 & (19) & 8 & (1) & 11 & $(10)$ & 57 & $(42)$ \\
\hline 1986 & 12 & (11) & 1 & $(0)$ & 18 & (18) & 10 & (8) & 15 & $(09)$ & 56 & $(46)$ \\
\hline 1987 & 11 & $(09)$ & & (1) & 19 & $(16)$ & 7 & $(0)$ & 13 & $(09)$ & 51 & (35) \\
\hline
\end{tabular}

a Numbers in parentheses indicate estimates from the May survey. 
61

were observed on sand banks more frequently (Mean $=79.0$, $\mathrm{SD}=15.1, \mathrm{n}=1658$ ) than on rocky banks (Mean $=12.6, \mathrm{SD}=$ 9.6, $\mathrm{n}=410$ ), grass banks (Mean $=4, \mathrm{SD}=6.0, \mathrm{n}=80$ ), sand-grass banks (Mean $=3.3 \mathrm{SD}=3.0, \mathrm{n}=126$ ), or in the river channel (Mean $=0.5 \mathrm{SD}=1.3, \mathrm{n}=10)$.

Habitat use by adult gharials in winter and summer was significantly different $(F=431.71$, df $=4,5 ; p<.05)$. An analysis of habitat use (Neu et al. 1974) indicated that gharials utilized sand banks in both winter and summer, and avoided grass, sand-grass and rock banks during both seasons (Table 5-4). 
Table 5-2. Surveys of released gharials in five sectors of the Narayani and Kali rivers in 1983, 1984, 1986 , and 1987.

\begin{tabular}{|c|c|c|c|c|c|c|}
\hline \multirow{3}{*}{$\begin{array}{l}\text { Year } \\
1983\end{array}$} & \multicolumn{6}{|c|}{ Numbers sighted by sector } \\
\hline & KALI & NASI & SIKH & KHMA & MATB & Total \\
\hline & $0(10)^{a}$ & 0 (2) & $53(49)$ & $21(09)$ & $10(8)$ & $84(78)$ \\
\hline 1984 & $0(00)$ & $0(0)$ & $50(42)$ & 25 (13) & 5 (1) & $80(56)$ \\
\hline 1986 & $0(00)$ & $0(0)$ & 38 (21) & 18 (21) & $4(2)$ & $60(44)$ \\
\hline 1987 & $0(00)$ & $0(0)$ & $31(30)$ & $10(08)$ & 11 (2) & $52(40)$ \\
\hline
\end{tabular}

a Numbers in parentheses indicate estimates from the May survey. 
Table 5-3. Habitat use by wild gharials in the Narayani River, 1987.

\begin{tabular}{|c|c|c|c|c|}
\hline \multirow[b]{2}{*}{ Habitat } & \multicolumn{2}{|c|}{$\begin{array}{c}\text { Proportion of Available } \\
\text { Habitat }\end{array}$} & \multicolumn{2}{|c|}{$\begin{array}{c}\text { Proportion of Use } \\
\text { Habitat }\end{array}$} \\
\hline & $\begin{array}{l}\text { June } \\
1987\end{array}$ & $\begin{array}{l}\text { January } \\
1988\end{array}$ & $\begin{array}{l}\text { Summer } \\
(\mathrm{N}=687)\end{array}$ & $\begin{array}{l}\text { Winter } \\
(\mathrm{N}=1091)\end{array}$ \\
\hline Sand bank & 0.17 & 0.83 & $0.85 *$ & $0.83 *$ \\
\hline Grass bank & 0.19 & 0.02 & $0.01 * *$ & $0.02 * \star$ \\
\hline Sand-grass bank & 0.11 & 0.04 & $0.04 * \star$ & $0.04 * \star \star$ \\
\hline Rock bank & 0.50 & 0.03 & $0.03 *$ & $0.03 * *$ \\
\hline River channel & 0.03 & 0.08 & $0.07 *$ & $0.08 *$ \\
\hline Total & 1.00 & 1.00 & 1.00 & 1.00 \\
\hline
\end{tabular}

* $\quad \mathrm{Z}>\mathrm{Z}_{.95} \quad$ = Habitat used less than expected

$\star \star \quad \mathrm{Z}<\mathrm{Z}_{025}=$ Habitat used more than expected

$\star \star \star \quad \mathrm{Z}_{.025}<\mathrm{Z}<\mathrm{Z}_{.95}=$ No preference in habitat selection 
Table 5-4. Habitat use by wild gharials in the Narayani River based on the frequency of sighting monthly, January to December, 1987.

\begin{tabular}{|c|c|c|c|c|c|c|}
\hline \multirow[b]{2}{*}{ Month } & \multirow[b]{2}{*}{$\begin{array}{c}\text { Frequency of } \\
\text { sightings }\end{array}$} & \multicolumn{5}{|c|}{ Percentage of Habitat use } \\
\hline & & $\begin{array}{l}\text { Sand } \\
\text { bank }\end{array}$ & $\begin{array}{l}\text { Grass } \\
\text { bank }\end{array}$ & $\begin{array}{l}\text { Sandgrass } \\
\text { bank }\end{array}$ & $\begin{array}{l}\text { Rock } \\
\text { bank }\end{array}$ & $\begin{array}{l}\text { River } \\
\text { bank }\end{array}$ \\
\hline February & 347 & 57.06 & 3.17 & 9.22 & 29.39 & 1.15 \\
\hline March & 405 & 63.95 & 0.49 & 9.63 & 25.68 & 0.25 \\
\hline April & 449 & 71.94 & 3.79 & 5.35 & 18.93 & 0.00 \\
\hline May & 298 & 68.46 & 4.03 & 6.04 & 21.48 & 0.00 \\
\hline June & 158 & 72.15 & 7.59 & 7.59 & 12.66 & 0.00 \\
\hline July & 59 & 61.02 & 20.34 & 1.69 & 16.95 & 0.00 \\
\hline August & 96 & 80.21 & 11.46 & 0.00 & 8.33 & 0.00 \\
\hline September & 65 & 92.31 & 3.08 & 0.00 & 4.62 & 0.00 \\
\hline october & 109 & 96.33 & 0.00 & 0.00 & 3.67 & 0.00 \\
\hline November & 78 & 96.15 & 1.28 & 0.00 & 2.56 & 0.00 \\
\hline December & 106 & 98.11 & 0.00 & 0.00 & 1.89 & 0.00 \\
\hline January & 110 & 90.35 & 0.00 & 0.00 & 5.26 & 4.39 \\
\hline
\end{tabular}




\section{Discussion}

The Narayani gharial population is concentrated mostly in the SIKH (50 gharials), KHMA (20) and MATB (21) sectors of the river. These areas are dissected by numerous river channels that provide high sand banks and deep pools, exceeding $7 \mathrm{~m}$ in depth. They provide the most suitable habitats for basking, foraging, and nesting. Few wild gharials were observed in the NASI (1) sector, which is more subject to human disturbance and lacks the numerous channels that provide deep pools and high sand banks. The last surviving population in the Kali sector includes three males and eight females; they are in jeopardy because the area is without the protection afforded by the RCNP. No gharial smaller than $3 \mathrm{~m}$ in length was observed in the Kali River, suggesting that recruitment is not occurring in this area. Loss of young animals is probably a natural phenomenon in this area due to the very fast current especially in the monsoons. The common problem shared by the gharials in these areas are poaching by local people. The protection of the gharials in the Kali River should be enforced; the area needs to be declared as a gharial sanctuary. In addition, more captive-reared gharials need to be stocked in the Kali River to make up for the lack of natural recruitment.

In 1980 , before the introduction of captive-reared gharials into the Narayani River, the overall density was 
estimated at 0.48 gharial $/ \mathrm{km}$. The density recorded during the last survey (1987), however, was $0.93 \mathrm{gharial} / \mathrm{km}$; the density varied from 0.8 (KHMA) to 1.1 (SIKH) gharial/km. Similarly, Sharma (1985) reported a density of 1.12 gharials/km in the Chambal River of India during 1981; gharial density increased to $1.43 / \mathrm{km}$ in $1983-1984$ and 1.85 in 1984-1985. The highest gharial densities recorded both in Nepal and India reflect the release of animals into the river systems; i.e., the densities of gharials in the 1.5 $2.0 \mathrm{~m}$ size classes contributed extensively to the overall population densities.

The frequency of sighting of gharials in the Narayani and Kali rivers is higher in winter (December-May) and lower in the summer and monsoons (June-November). The lower sighting rates of gharial during the monsoon are probably due to animals being dispersed coupled with the fact that they do not bask as much as during summer surveys. Also, during the pre-monsoon, when water levels start to rise, most of the fishes (e.g, Tor putitora) migrate upstream for breeding which marks the time that local fishermen move frequently in the river to catch the fish, causing disturbances for basking gharials.

Though individual movements of wild gharials were not studied, they obviously move some distance during the nesting and monsoon periods. Tributaries of the Narayani River provide additional habitat during the monsoon period 
as adults of both sexes were observed in the Rapti River, about $50 \mathrm{~km}$ upstream of the confluence of the Narayani and Rapti rivers. They remained there until september, and then moved back to the Narayani River by early october. Bustard and singh (1982) suggested that the movement of adult gharials into sidestreams during monsoon floods may be associated with dispersal of their fish prey. During high floods, both fish and gharials enter side streams, probably to avoid the force of waterflow in the main river.

Bustard and Singh (1982) studied the movements of four adult gharials in the Mahanadi River and found the extent of movement much greater than anticipated. Individual gharials made long-range movements up to $44 \mathrm{~km}$. The mugger crocodile, crocodylus palustris, a sympatric species, apparently does not range widely, moving a maximum distance of only $10.7 \mathrm{~km}$ in an 18 month period (Bustard and singh, 1982).

Adult gharials used sand banks more frequently than any other habitat during both winter and summer. The second most commonly used habitat was the river channel itself. Adult gharials used rock banks less than the small gharials (see Chapter VI). The more frequent use of rocky banks by small animals may be associated with their comparative lack of experience. Most of the use of rocky banks were by recently (within one season) released animals. Because both small and large animals have been observed on the same banks 
with no apparent conflict, avoidance of larger animals is not a satisfactory explanation.

Gharials bask on the sand banks for long periods during the winter when water temperatures and water level is low. Whitaker et al. (1974) remarked on the gharial's predictable habit of returning to the same spot every day for basking, which contributes to their vulnerability to poaching. Sand banks for both basking and nesting are important habitats for gharial survival. The highest densities of gharial in the Narayani were observed in areas where the maximum occurrence of sand banks and deep channels were available. In winter, gharials appear to spend most of their time basking and less time feeding, presumably to avoid the coldness of the water. In contrast, in summer, they spend most of their time in water to avoid the heat of the day. Thermoregulation and dietary needs appear to be important factors in determining their use of sand banks. 
CHAPTER VI

HUSBANDRY OF THE GHARIAL IN

ROYAL CHITWAN NATIONAL PARK

\section{Introduction}

The gharial, Gavialis gangeticus, a fresh water crocodile, was once widely distributed in the major river systems of South Asia (see Chapter III). In the past two decades, there has been a drastic decrease in gharial populations and their habitats; populations in some rivers are now extinct. Because the gharial was on the verge of extinction, captive breeding programs were implemented both in India and Nepal. Although these captive breeding programs are the policies of last resort, they can assure species survival and stocks for reintroduction (Bustard 1984). Additionally, India and Nepal also have initiated programs to rear gharials in captivity from eggs collected in the wild (Maskey 1984, Singh 1987). These efforts are based on the fact that small gharials $(<2 \mathrm{~m})$ have high attrition rates (Singh 1978, Mitra 1979, Maskey 1988 Chapter VI), which results in low recruitment (if any) of wild young gharials. A major cause of the population decline in Nepal has been the flooding of nests caused by the damming of rivers. This study was designed to provide information on 
nesting biology, of wild gharials, that, inturn, could be applied to husbandry techniques including incubation and captive rearing.

\section{Methods}

Methods adopted for wild nest location were similar to those used by poachers. The nesting (egg-laying) season does not vary more than 10 days in India and 15 days in Nepal. Egg laying begins in the last week of March and ceases about the third week of April. After mid-March, the banks of the Narayani River were scouted for trial nesting sites. Pre-nesting behavior consisted of excavation of trial nests by the females about 3-4 weeks before actual nesting (Singh, L. 1978, Singh, V. 1978). Trial nests were located, marked, and observed daily until egg laying began. After all nesting activities ceased (1-2 weeks), each trial nest was excavated carefully. Once an active nest was located, the distance and height of each nest from the river were measured. The sandy plug of the nest was gently scooped out by hand until exposure of the first egg. Temperature of the nest cavity and depth to the first egg were measured before further exposing the eggs. All eggs were carefully uncovered and removed, avoiding rotation of the egg. The top of each egg was marked next to the opaque band with a waterproof marking pen prior to removal to 
maintain original orientation (Joanen et. al. 1977; Rao 1987; Woodward et al. in press). After the collection of all eggs, depth to the bottom of the nest cavity was measured.

The length, width and weight of each egg were measured with calipers and a spring balance. Each clutch was arranged in tiers in separate wooden or metal crates (60 $\mathrm{x}$ $45 \times 45 \mathrm{~cm})$. The crated eggs were insulated on the bottom with a $10 \mathrm{~cm}$ layer of moist river sand from the nest vicinity; a 2-3 cm layer of sand was placed between tiers of eggs, and a $30 \mathrm{~cm}$ layer of sand was put on top.

The crates were transported by dugout canoe to the hatchery facility. During 1977 and 1978, eggs were incubated in their crates within a room maintained at 32$34^{\circ} \mathrm{C}$ by a kerosene heater. In 1979-1987, each clutch was transferred carefully into a freshly dug pit on the river bank above the high water mark. Pits were dug to a depth of $60 \mathrm{~cm}$, the average depth of natural nests. Orientation of eggs as found in original clutches was maintained in the collected clutches. The eggs were covered with sand and left to incubate. The hatching area was securely fenced and watchmen were assigned to protect the eggs from depredation by jackals, mongoose, civets, and humans.

During incubation, clutches were monitored regularly until hatching. Air and nest temperatures were noted every 3 hours. The latter were measured by pushing a thermometer 
into the sand to a depth of $30 \mathrm{~cm}$ and recording temperature after 2 minutes. As with other crocodilians, embryos begin croaking immediately before hatching. After initial croaking was noted, 24-36 hrs. was allowed to elapse until a chorus was obvious, and the incubation pit was excavated. In most cases, the snouts would have pierced through the shell membrane. The young crocodiles were allowed to hatch naturally and those not hatching after 24 hours were handassisted. Total body length and weight of each hatchling were measured with a ruler and spring balance, respectively. Hatchlings were transported quickly to the rearing facility in Royal Chitwan National Park where they were placed in concrete pools ( $2 \times 2 \times 1 / 2 \mathrm{~m})$, around the edge of which sand was provided for basking. After 1 year, the gharials were shifted to larger pools $(4 \times 4 \times 1 \mathrm{~m})$ and reared to a release size of $1.5-2.0 \mathrm{~m}$. The water in the pools was piped from a nearby river.

A dozen Botes (local fishermen) were employed to feed the crocodiles a diet of fresh fish from the nearby river. Hatchlings were fed small $(<7 \mathrm{~cm})$ live fish and yearlings were fed large $(>10 \mathrm{~cm}$ ) dead fish. Fish were weighed before feeding and uneaten portions were weighed during pool cleaning. Average food consumption was determined by dividing the weight of consumed fish by the number of gharials in each pool. 


\section{Results}

\section{Nesting Season}

Gharials on the Narayani River are predictably synchronized nesters with egg laying occurring between 25 March and 18 April. The nesting period, which occurs between the cold winter months and the monsoon floods, is characterized by high ambient temperatures. Mean oviposition date for clutches collected from 1977 to 1987 was April 3 on the Narayani River and April 6 on the Kali River (Table 6-1). The earliest deposition date observed was March 25, 1987 on the Narayani River, and the latest was April 18, 1977 on the Kali River. Overall, 75 of of nesting was completed by April 4 on the Narayani and April 10 on the Kali River.

\section{Nesting Sites}

Fine sand banks were chosen as nesting sites in preference to alluvial sand banks. About $90 \%$ of the 73 nests located were found on fine sand banks, and only $10 \%$ of the nests were located on the lower quality alluvial sand banks. Of the 73 nests collected during 1977-1987, 37\% $(n=27)$ were collected from MATB, $27 \%(n=20)$ from SIKH, and $27 \%(n=20)$ from KALI sectors of the Narayani River. Few nests were collected from KHMA $(7 \%, \mathrm{n}=5)$ and NASI 
Table 6-1. Oviposition dates for gharial clutches collected from the Narayani and Kali Rivers, 1977-1987.

\begin{tabular}{cccccc}
\hline & & $\begin{array}{c}\text { Mean } \\
\text { oviposition } \\
\text { date }\end{array}$ & $\begin{array}{c}75 \text { \% } \\
\text { oviposition } \\
\text { date }\end{array}$ & Range \\
\hline Narayani River & 53 & 3 April & 4 April & 24 Mar -13 Apr \\
Kali River & 20 & 6 April & 10 April & 25 Mar -18 Apr \\
Total & 73 & & 4 April & 7 April & 24 Mar $-18 A p r$ \\
Mean & & &
\end{tabular}


(1\%, $\mathrm{n}=1$ ) sectors. Nest holes were located between $5-20 \mathrm{~m}$ (Mean $=12.35, \mathrm{SD}=4.17, \mathrm{n}=10)$ from the river edge and 3-7 $\mathrm{m}($ Mean $=5.30, \mathrm{SD}=1.49, \mathrm{n}=10)$ above the water level. Nests were usually excavated to levels (Mean $=60$ $\mathrm{cm}$ ) where the sand was noticeably damp. Nest pit depth was poorly correlated $\left(r^{2}=0.13\right)$ with the clutch mass.

\section{Clutch and Egg gharacteristics}

Information on clutch size was collected from 73 nests, 20 from the Kali River and 53 from the Narayani River, during the 6 nesting seasons of 1977-81 and 1987 (Table 61). The mean clutch size of nests from the two river systems differed significantly (t-test, df $=68, P<.05$ ), with a mean of $34.4 \pm 10.7 \mathrm{SD}$ eggs $(n=53)$ from the Narayani River and $37.0 \pm 4.9 \mathrm{SD}$ eggs $(n=20)$ from the Kali River (Table 6-2). The combined intra-year clutch sizes ( $r^{2}$ $=.09, \mathrm{df}=1, \mathrm{P}>.05)$ and inter-year clutch sizes $(\mathrm{F}=$ 1.35, df $=1,5 ; \mathrm{P}>.05)$ of Narayani and Kali rivers were not different, except for the mean clutch size in 1987, which differed $(P<.05)$ from the mean clutch size in 1978 . No gharial clutch was observed to contain less than 14 eggs (Appendix D) - Clutch sizes were distributed normally, but showed some skewness towards the left side ( Kurtosis = -0.14) of the normal curve (Fig. 6-1). of 73 nests $48 \%$ $(n=35)$ contained $31-40$ eggs, and $22 \%(n=16)$ contained 41-50 eggs. 
Mean egg length was $84.5 \pm 3.3 \mathrm{~mm} S D(n=406)$; width $58.1 \pm 1.8 \mathrm{~mm} S D(n=406) ;$ and egg weight $165.7 \pm 12.2 \mathrm{~g} \mathrm{SD}$ $(n=406)$. One dimension of the egg could be predicted by the measurement of a second dimension (Table 6-3). The prediction of egg weight by measuring egg length and egg diameter was more reliable $\left(r^{2}=0.64\right)$ than predicting weight, length, and diameter by measuring length, diameter, and weight, respectively $\left(r^{2}=0.21\right)$.

Egg weight showed the greatest variation (6.3\%) (Sokal and Rohlf 1981), followed by length (3.0\%) and diameter (1.1\%). Total mean clutch weight (mean egg weight $\mathbf{x}$ clutch size) was $6726.0 \pm 1153.1 \mathrm{~g} \mathrm{SD}(\mathrm{n}=10$, range $4910-8470 \mathrm{~g})$, and correlated more highly with clutch size $\left(r^{2}=.89\right.$ ) (Fig. 6-2) than mean egg weight $\left(r^{2}=.26\right)$ (Fig. 6-3) .

\section{Nest Temperatures}

The mean daytime air temperatures for the month of May and June at the hatchery site was $33.0 \pm 6.6^{\circ} \mathrm{C} S D$ (range 21 $-43^{\circ} \mathrm{C}$ ) and $30.8 \pm 4.2^{\circ} \mathrm{C} S D$ (range $24-40^{\circ}$ ), respectively (Fig. 6-4). The mean daytime nest temperature recorded at $30 \mathrm{~cm}$ below ground level was $31.7 \pm 2.0^{\circ} \mathrm{C} S D$ (range $27-35^{\circ} \mathrm{C}$ ) and $32.1 \pm 2.4^{\circ} \mathrm{C} \mathrm{SD} \mathrm{(range} 26-36^{\circ} \mathrm{C}$ ) during the months of May and June, respectively. The mean water temperatures for the months of May and June were $24.2 \pm 1.0^{\circ} \mathrm{C} S D$ (range $21-28^{\circ} \mathrm{C}$ ) and $25.1 \pm 1.4^{\circ} \mathrm{C} \mathrm{SD}$ (range $22-31^{\circ} \mathrm{C}$ ), respectively (Fig. 64). 
Table 6-2 Mean size of gharial clutches, Narayani and Kali rivers, 1977-1987.

\begin{tabular}{lrrrrrrrrr}
\hline & \multicolumn{4}{c}{ N } & \multicolumn{3}{c}{ Narayani River } & \multicolumn{3}{c}{ Kali River } \\
Year & N & Mean & SD & Range & N & Mean & SD & Range \\
\hline 1977 & 13 & 37.1 & 10.9 & $16-61$ & 3 & 36.3 & 1.1 & $35-37$ \\
1978 & 9 & 30.8 & 10.1 & $18-45$ & 1 & 33.0 & - & - \\
1979 & 13 & 33.2 & 12.5 & $14-52$ & 3 & 37.0 & 9.5 & $27-46$ \\
1980 & 6 & 29.3 & 13.4 & $14-52$ & 2 & 44.0 & 2.8 & $42-46$ \\
1981 & 6 & 33.3 & 2.3 & $30-36$ & 7 & 35.9 & 3.8 & $31-41$ \\
1987 & 6 & 43.0 & 4.9 & $37-51$ & 4 & 37.0 & 4.1 & $31-40$ \\
Total & 53 & 34.4 & 10.7 & $14-61$ & 20 & 37.0 & 4.9 & $27-46$ \\
\hline
\end{tabular}


Table 6-3 Formulae for predicting one dimension of size of gharial eggs when second dimension is known.

Sought Known

value value

Formulae

SE

$\mathrm{R}^{2}$

\begin{tabular}{lllll}
\hline Weight $(\mathrm{g})$ & Length $(\mathrm{mm})$ & $\mathrm{W}=50.189+0.207 \mathrm{~L}$ & 2.15 & 0.21 \\
Weight & Diameter $(\mathrm{mm})$ & $\mathrm{W}=46.794+0.068 \mathrm{D}$ & 1.64 & 0.21 \\
Weight & Length/Diameter & $\mathrm{W}=-148+2.5 \mathrm{~L}+1.7 \mathrm{D}$ & 7.30 & 0.64 \\
Length & Weight & $\mathrm{L}=-71.128+2.803 \mathrm{~W}$ & 7.90 & 0.58 \\
Diameter & Weight & $\mathrm{D}=-9.076+3.007 \mathrm{~W}$ & 10.87 & 0.21
\end{tabular}




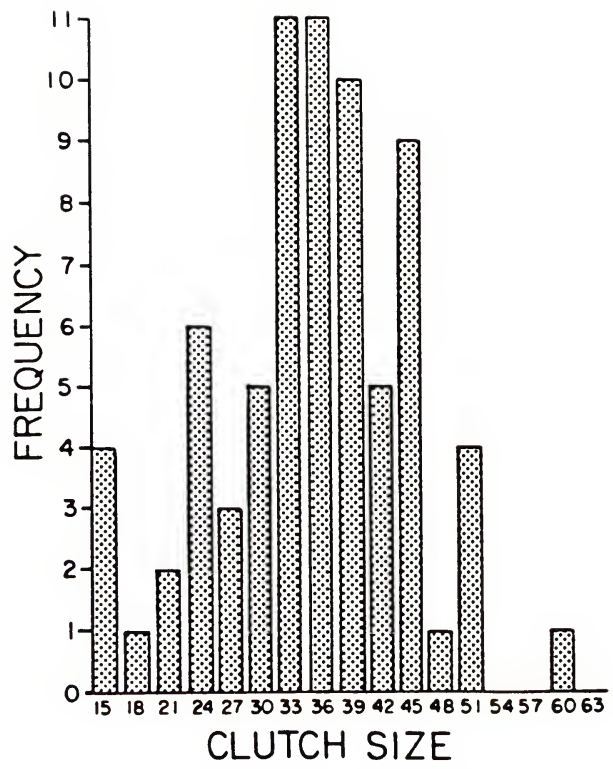

Figure 6-1. Clutch size distribution of gharial nests, Narayani and Kali rivers, 1977-1987. 


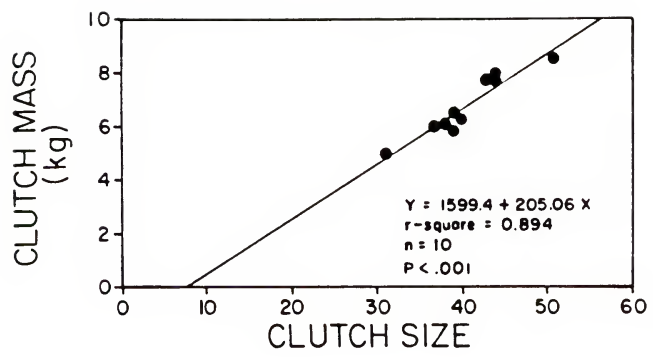

Figure 6-2 Relation between clutch size and clutch weight during the 1987 nesting season.

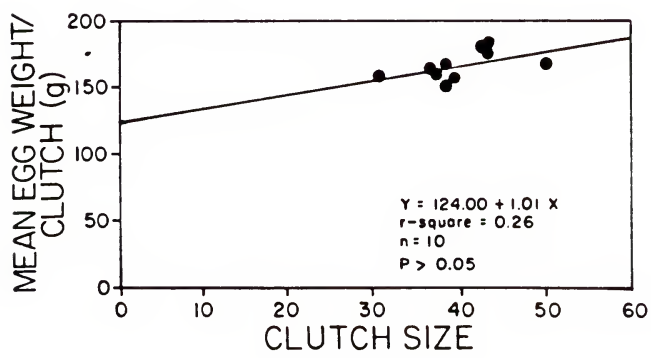

Figure 6-3. Relation between clutch size and egg weight during the 1987 nesting season. 

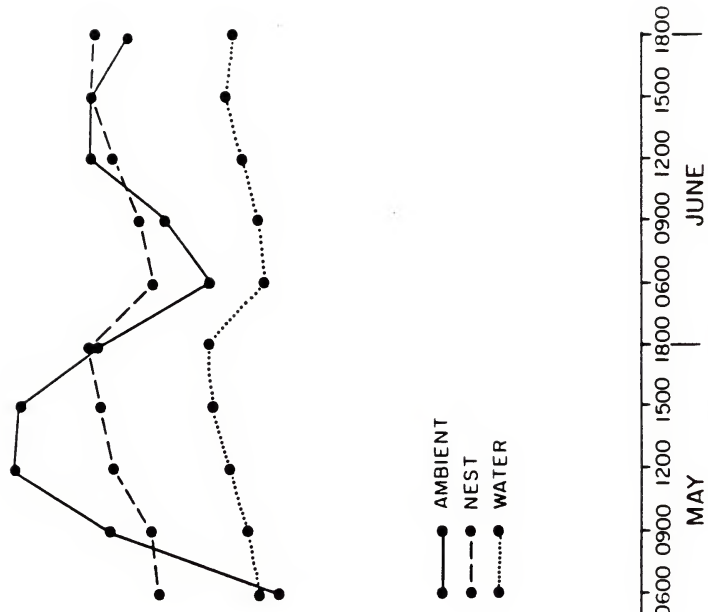

ขึ

늠 $\overbrace{0}^{\infty}=\dot{4}$ 성 i $\infty$ 윽 E्d $\rightarrow$ $+=-1$ น ญ ข 5

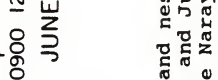

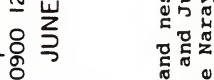

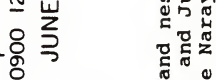
ㅇ 5 눙 - ㄸ ㄷำ ㅇ Z ही. - $\leq$ त्र

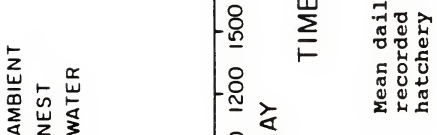

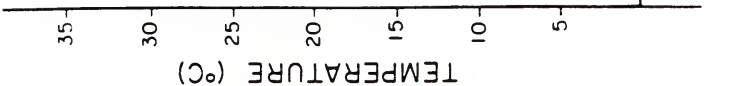


Table 6-4. Mean incubation periods (in days) for gharial clutches, Narayani and Kali rivers, 1977-1987.

\begin{tabular}{|c|c|c|c|c|c|c|c|c|}
\hline Year & $\mathrm{N}$ & $\begin{array}{r}\mathrm{N} \\
\text { Mean }\end{array}$ & $\begin{array}{c}\text { Cayan } \\
\text { SD }\end{array}$ & $\begin{array}{l}\text { River } \\
\text { Range }\end{array}$ & N & Mean & \multicolumn{2}{|c|}{ Kali River } \\
\hline 1977 * & 13 & 95.1 & 3.8 & $91-102$ & 3 & 87.0 & 6.1 & $83-94$ \\
\hline 1978 * & 9 & 83.9 & 7.2 & $72-99$ & 1 & 104.0 & - & - \\
\hline 1979 & 13 & 67.9 & 4.5 & $60-74$ & 3 & 70.0 & 4.0 & $66-74$ \\
\hline 1980 & 6 & 69.0 & 3.3 & $63-73$ & 2 & 69.5 & 9.2 & $63-76$ \\
\hline 1981 & 6 & 81.2 & 6.3 & $74-89$ & 7 & 77.6 & 3.1 & $74-83$ \\
\hline 1987 & 6 & 76.8 & 2.7 & $73-79$ & 4 & 75.8 & 2.9 & $72-78$ \\
\hline Total & 53 & 80.0 & 11.6 & $63-99$ & 20 & 78.0 & 9.0 & $63-104$ \\
\hline
\end{tabular}

* Eggs incubated under artificial (kerosene heater) condition. 


\section{Incubation Period}

The mean incubation period of nests from the Kali and Narayani river were $78 \pm 9.0 \mathrm{SD}$ days and $80 \pm 11.6 \mathrm{SD}$ days, respectively (Table 6-4). A maximum incubation period of 104 days was recorded for a nest from the Kali River in 1978; a minimum incubation period of 60 days was recorded for a nest from the Narayani River in 1979 (Appendix D). Mean incubation periods for each of the 6 years differed significantly $(F=44.46, D F=5,67 ; p<$ .05). The incubation periods during 1977 (Mean $=93.6 \pm$ 5.21 SD days) and 1978 (Mean $=85.9 \pm 9.3 \mathrm{SD}$ days) were greater than for other years (Table 6-4). Incubation periods were strongly correlated with the ambient temperature $\left(r^{2}=0.60\right)$, following the equation: $y=46.29+$ $0.15 \mathrm{I}$, where $\mathrm{I}$ is the incubation period $(\mathrm{F}=151.34$, df $=$ $1,8 ; \mathrm{P}<.05)$.

\section{Hatching}

The absence of gharial tracks in the early stages of the incubation period indicated that the females had not attended the nest during incubation. Females did, however, guard nest sites when hatching was eminent. Under natural conditions, adult females excavate nests when hatchlings begin to call. Hatching rates of eggs in fertile clutches in the artificial hatchery varied from a low of 38 for a Kali River clutch in 1981, to 1008 for a Narayani River 
clutch in 1979 (Table 6-5). Altogether five totally infertile nests were observed in the 6 years, 1977-1981, and 1987 (Appendix D). Hatching rates of eggs did not differ between Kali and Narayani river nests $(t=0.11$, df $=71, P$ $>$.05) (Table 6-5). Mean egg hatching rates did not differ among the 6 years $(F=1.32, \mathrm{df}=5,66 ; \mathrm{P}>.05)$.

\section{Mortality}

Between 25 and $80 \%$ of the captive gharial hatchlings died within the first year of their life in the Chitwan facility. Most $(12-36 \%)$ of the hatchlings died within 3 months (Table 6-6). The major causes of hatchling mortality in the nursery were necrotizing skin disease (Jacobson 1982), neurological disorders, bloated stomach (unabsorbed yolk) and prolapsed rectum. In the second year, about $10 \%$ of the yearlings died with most deaths occuring during the monsoon period at which time poor water quality and extreme humidity resulted in a high incidence of mycotic infections.

\section{Anomalies}

Two unusually large eggs, each having two yolks, were collected from same nest in the Narayani River in 1979; each measured $120 \mathrm{~mm}$, or about twice the length of normal gharial eggs. Neither of these eggs hatched. 
Table 6-5. Mean hatching success (in percent) for gharial clutches, Narayani and Kali rivers, 1977-1987.

\begin{tabular}{|c|c|c|c|c|c|c|c|c|}
\hline Year & $\mathrm{N}$ & $\begin{array}{l}\text { Na } \\
\text { Mean }\end{array}$ & $\begin{array}{l}\text { ayani } \\
\text { SE }\end{array}$ & $\begin{array}{l}\text { River } \\
\text { Range }\end{array}$ & $\mathrm{N}$ & Mean & $\underset{\mathrm{SE}}{\mathrm{Kali}} \mathrm{Ri}$ & $\begin{array}{l}\text { ver } \\
\text { Range }\end{array}$ \\
\hline 1977 & 13 & 66.3 & 17.2 & $34-97$ & 3 & 84.6 & 15.3 & $68-97$ \\
\hline 1978 & 9 & 52.0 & 35.6 & $00-95$ & 1 & 6.1 & - & - \\
\hline 1979 & 13 & 61.0 & 34.7 & $04-100$ & 3 & 28.7 & 16.0 & $11-41$ \\
\hline 1980 & 6 & 79.1 & 21.3 & $45-95$ & 2 & 55.3 & - & - \\
\hline 1981 & 6 & 39.2 & 36.1 & $00-83$ & 7 & 63.0 & 37.3 & $3-97$ \\
\hline 1987 & 6 & 51.8 & 48.4 & $00-98$ & 4 & 77.1 & 26.8 & $37-95$ \\
\hline Total & 53 & 60.9 & 33.2 & $00-100$ & 20 & 60.9 & 34.9 & $3-97$ \\
\hline
\end{tabular}


Only $3.9 \%$ of all hatchlings showed any kind of anomalies. No difference in anomalies appeared to exist between hatchlings from the Kali and Narayani rivers. The most common defects (about 20\%) were crooked vertebrae (cervical, abdominal, thoracic and caudal) and bulged abdomens (unabsorbed yolk). Most hatchlings with abnormalities failed to emerge from the egg by themselves and none survived. Complete absence of both eyes was observed in two hatchlings from the Kali River in 1978 and 1979; in neither case, was there any sign of development of embryonic eye buds.

Three hatchlings from 1979 and 1980 had crossed snouts --the upper jaw crossed over the lower jaw and projected to the side. This defect was not pronounced at hatching, but became more evident within 1 week. Four hatchlings from 1987 had short upper snouts with exposed nares at the snout tip; they survived only 2 hours. One pair of siamese twins (joined the entire length of the body except for the head) and one pair of twins hatched from normal sized eggs from a single Banderjhola Island nest in 1978. The siamese twin died immediately after hatching and the other pair of twins died in 1 week and the other in 3 weeks, respectively. The individual twin animals were very small. 
Table 6-6. Age-related mortality of captive gharials during the first year after hatching, Royal Chitwan National Park, Nepal.

\begin{tabular}{|c|c|c|c|c|}
\hline \multirow[b]{2}{*}{$\begin{array}{l}\text { Age in } \\
\text { days (month) }\end{array}$} & \multicolumn{4}{|c|}{ Number of hatchling deaths } \\
\hline & $\begin{array}{c}1978 \\
(\mathrm{~N}=162)\end{array}$ & $\begin{array}{c}1979 \\
(N=294)\end{array}$ & $\begin{array}{c}1980 \\
(N=187)\end{array}$ & $\begin{array}{c}1981 \\
(N=64)\end{array}$ \\
\hline $00-30 \quad$ (Jun) & $-\star$ & $5(01.7) \star \star$ & $1(00.5)$ & - \\
\hline $31-60$ (Jul) & - & $39(13 \cdot 3)$ & $2(01.1)$ & - \\
\hline $61-90$ (Aug) & $19(11.7)$ & $62(21 \cdot 1)$ & $30(16.0)$ & $2(03.1)$ \\
\hline $91-120$ (Sep) & $5(03.1)$ & $13(04.4)$ & $28(15.0)$ & $21(32.8)$ \\
\hline $121-150$ (Oct) & $4(02.5)$ & $2(00.7)$ & $10(05.3)$ & $8(12 \cdot 5)$ \\
\hline $151-180$ (Nov) & $4(02 \cdot 5)$ & - & $1(00.5)$ & $4(06.2)$ \\
\hline $181-210(\mathrm{Dec})$ & $4(02.5)$ & - & $2(01.1)$ & $6(09.4)$ \\
\hline $211-240$ (Jan) & $3(01.8)$ & $4(01.4)$ & $5(02.7)$ & $7(10.9)$ \\
\hline $241-270(\mathrm{Feb})$ & - & - & $5(02.7)$ & $4(06.2)$ \\
\hline $271-300$ (Mar) & $1(00.6)$ & - & $1(00.5)$ & $1(01.6)$ \\
\hline $301-330$ (Apr) & $1(00.6)$ & $4(01.4)$ & $2(01.1)$ & - \\
\hline $331-360$ (May) & - & - & $2(01.1)$ & - \\
\hline $\begin{array}{l}\text { Total deaths } \\
\text { (year } 1 \text { ) }\end{array}$ & $40(24 \cdot 7)$ & $130(44.2)$ & $89(47.6)$ & $53(82.8)$ \\
\hline
\end{tabular}

* No deaths observed

** Numbers in parenthesis denote percentages of initial sample of hatchlings. 
Table 6-7. Age-related mortality of captive gharials during the second year after hatching, Royal Chitwan National Park, Nepal.

\begin{tabular}{|c|c|c|c|c|}
\hline \multirow[b]{2}{*}{$\begin{array}{l}\text { Age in } \\
\text { days (month) }\end{array}$} & \multicolumn{4}{|c|}{ Number of hatchling deaths } \\
\hline & $\begin{array}{c}1978 \\
(\mathrm{~N}=162)\end{array}$ & $\begin{array}{c}1979 \\
(N=294)\end{array}$ & $\begin{array}{c}1980 \\
(\mathrm{~N}=187)\end{array}$ & $\begin{array}{c}1981 \\
(N=64)\end{array}$ \\
\hline $361-390$ (Jun) & $-\star$ & $2(1.2) * *$ & $1(1.0)$ & - \\
\hline $391-420$ (Jul) & $5(4.1)$ & $1(0.6)$ & $2(2.0)$ & - \\
\hline $421-450$ (Aug) & $10(8.2)$ & $2(1.2)$ & - & - \\
\hline $451-480$ (Sep) & - & $1(0.6)$ & - & - \\
\hline $481-510$ (Oct) & - & $3(1.8)$ & - & - \\
\hline $511-540$ (Nov) & - & $1(0.6)$ & - & - \\
\hline $541-570$ (Dec) & - & - & - & - \\
\hline $571-600$ (Jan) & - & - & - & - \\
\hline $601-630$ (Feb) & - & - & - & - \\
\hline $631-660$ (Mar) & - & - & - & - \\
\hline $661-690$ (Apr) & $1(0.8)$ & - & - & - \\
\hline $691-720$ (May) & - & - & $2(2.0)$ & - \\
\hline $\begin{array}{l}\text { Total deaths } \\
\text { (year 2) }\end{array}$ & $16(13.1)$ & $10(6.1)$ & $5(5.1)$ & - \\
\hline
\end{tabular}

* No deaths observed

** Numbers in parentheses denote percentages of initial sample of hatchlings. 
Feeding and Growth Rates

Rate of average food intake by hatchlings was 4 times higher during the summer and monsoon seasons (861.33 \pm 383.19 SD gm/individual/month) than during the winter season (209.22 $\pm 51.19 \mathrm{SD} \mathrm{gm} /$ individual/month). Consumption rates were 2.5 and 1.75 times greater in summer than in winter in the gharial's second and third years, respectively (Fig 65). Growth rates, with respect to both weight and length, were greater in summer than in winter. There was a strong correlation between the rate of increase in body weight and the rate of increase in whole body length for hatchlings from $1978\left(r^{2}=0.81, d f=33\right), 1979\left(r^{2}=0.82, d f=26\right)$, $1980\left(r^{2}=0.91, \mathrm{df}=19\right)$, and $1981\left(r^{2}=0.73\right.$, df $\left.=11\right)$ (Fig. 6-6) 
(b) $\exists Y \forall \perp N 1$ 000

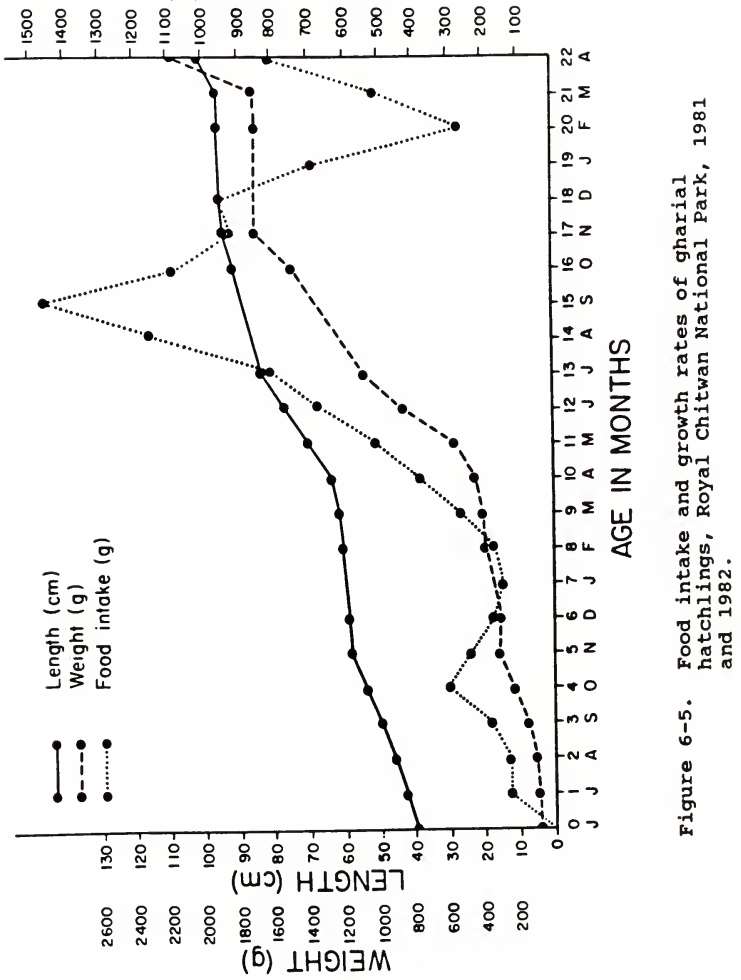




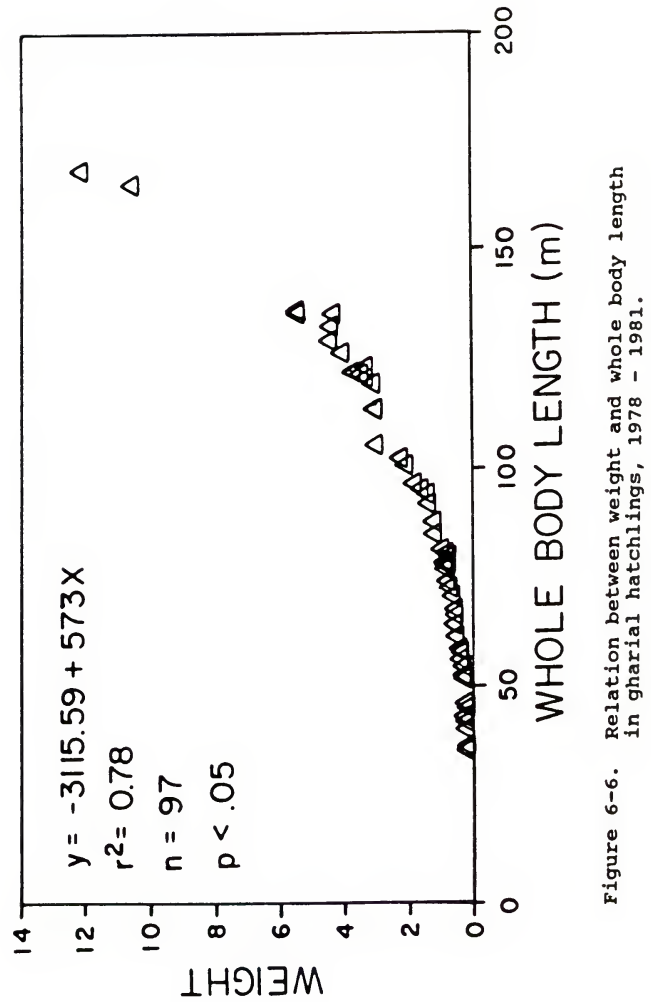




\section{Discussion}

Because crocodilians range over wide areas with drastically varying climatic conditions, the egg-laying period varies by area; however, all crocodilians are synchronized to lay their eggs during the wet season of the year. Gharials are predictably synchronized nesters; in Nepal, all clutches were deposited between March 24 and April 18, with $75 \%$ being laid by April 7. In India, Whitaker and Basu (1983) recorded the earliest gharial nest on April 7 in the Chambal River. In contrast, Alligator mississippiensis in Florida (USA), does not reach the $75 \%$ clutch deposition point until July (Woodward et al. in press). Hall and Johnson (1987) reported that $95 \%$ of Crocodylus novaenguinea egg laying in Papua New Guinea occurred during the wet season (November-May). The peak time of egg laying for crocodylus palustris in India and Nepal also occurred during the wet season (February-August) (Whitaker and Whitaker 1984, Ferguson 1985).

Numerous reports for various species of crocodiles suggest a possible correlation between breeding time and changing water levels (Ferguson 1985). For gharials, egg laying and incubation were synchronized with high temperature and humidity, and hatching with high water levels. Nesting during the early part of the season is advantageous to gharials because (a) the high constant 
temperature and high humidity ensure better embryonic survival, development, and growth within the egg chamber, (b) flooding of nest sites is avoided and, (c) young are ready to hatch when water levels are high, allowing hatchlings to disperse to the small tributaries of the Narayani River where small fishes are available, thereby increasing chances of survival.

Natural nesting success of gharials in the Narayani River also is dependent upon the type and location of nesting sites in relation to the water level of the river. However, the Tribeni dam causes water levels to rise earlier and higher than normal, jeopardizing natural nesting success. In this study, nests were located on fine sand banks at a position 3 to $7 \mathrm{~m}$ above the water level and 5 to $20 \mathrm{~m}$ from the water. In India, Whitaker and Basu (1983) found nests were 1 to $5 \mathrm{~m}$ above the water level and $10 \mathrm{~m}$ away from the river. Singh and Bustard (1977) described a nest of 25 eggs in Satkosia Gorge (India) being $2.6 \mathrm{~m}$ above the water level and $5.9 \mathrm{~m}$ from the water's edge. Nests collected in proximity to the Tribeni dam in Nepal in 1987 were higher above the water level (6-7 m) than nests on the Kali River (4 $\mathrm{m}$ ) and middle portions of the Narayani River $(3 \mathrm{~m})$. The area near the dam floods earlier than upstream areas; thus, animals may select higher sites in these areas. The fine-sand sites are important for the success of nesting in the Narayani River, but hydrologically these areas are 
now subject to flooding, which results in the failure of natural nesting.

Whitaker (1984) reported that gharials are possibly communal nesters, as has been reported for Nile crocodiles (Cott 1961) and for American alligators (Woodward et al. 1984). Percival (pers. comm. 1988) has observed as many as three American alligators sharing a single nest mound in Florida wetlands. Basu (1980) reported three gharial nests on a $30 \mathrm{~m}$ sand bar in the Chambal River. In 1987, 5 active gharial nests were located within $3 \mathrm{~m}$ of each other on a 50 $m$ sand bar on the Narayani near the dam. In the Kali River two nests were located within $2 \mathrm{~m}$ of each other. These observations indicate that habitat availability present very attractive possibilities for constructing a nest at the same site.

Gharials show a strong preference for fine-sand banks for nesting. Because of the restricted availability (25\%, see Chapter IV) of elevated sand banks and disturbance created by the local settlers, gharials probably are limited in their nesting space. In the Bandarjhola portion of the river, the nests were scattered, which may reflect the comparative availability of sand banks and less severe flooding potential.

Mean clutch sizes of gharials varied among years in both the Narayani and Kali rivers. Mean clutch size of the Kali River was larger (Mean $=36.2, \mathrm{SD}=4.9, \mathrm{n}=20$ ) than 
that of Narayani River (Mean $=34.4, \mathrm{SD}=10.7, \mathrm{n}=53$ ). Bustard (1972) also indicated differences in mean clutch sizes among years and postulated that clutch size is correlated positively with size of the breeding female. Ferguson (1985) indicated that there was a significant, but highly variable, correlation between the number of eggs per clutch and the body length of the laying female. Deitz and Hines (1980), working with the American alligator argued that clutch weight rather than clutch size may be a better indication of female size. In 1987, Hall and Johnson (1987) reported that both clutch mass $\left(r^{2}=0.83\right)$ and clutch size $\left(r^{2}=0.77\right)$ of $c$. novaeguinea were highly correlated with female size. In the Kali River, the larger observed clutch size may be attributed to the presence of larger females. Annual variation in clutch weights and sizes also may reflect variation in the size/age profile of nesting females. The lower clutch mass (and larger standard deviation) in the Narayani River may reflect a size class distribution of smaller females.

Among crocodilians, gharial eggs have been reported to be the second largest in size and weight (Ferguson, 1985). The largest eggs were from captive Tomistoma schlegelii (Mean length $=101 \mathrm{~mm}$, range $=97-120 \mathrm{~mm}$, Mean diameter $=76$ $\mathrm{mm}$, range $=64-80 \mathrm{~mm}$. Percival (unpubl. data, 1988) recorded average dimensions of alligator egg from Lakes okeechobee, George and Jessup (Florida) as $73.6 \pm 4.1 \mathrm{~mm} \mathrm{SD}$ 
(length) $\times 43.9 \pm 2.5 \mathrm{~mm}$ SD (diameter); clutch mass was 3409 g. Mean linear dimensions and mass of eggs measured for $\underline{c}$. novaeguineae were $79.5 \pm 2.8 \mathrm{~mm} \mathrm{SE} \times 46.8 \pm 1.1 \mathrm{~mm} \mathrm{SD}$ and $103.5 \pm 5.6 \mathrm{gm} \mathrm{(Hall} \mathrm{and} \mathrm{Johnson} \mathrm{1987).} \mathrm{Similarly,} \mathrm{the}$ average size of wild $\underline{c}$. palustris eggs from South India was $74 \mathrm{~mm} \times 47 \mathrm{~mm} \times 128 \mathrm{~g}$ (Whitaker and Whitaker 1983). The average size of $\underline{c}$. palustris eggs from the Narayani River were $78.9 \pm 5.3 \mathrm{~mm} \mathrm{SD} \times 49.6 \pm 2 \mathrm{~mm} \mathrm{SD} \times 114.2 \pm 11.3 \mathrm{gm} \mathrm{SD}$ Among crocodilians, nest temperature and humidity are important factors for embryonic survival, development and growth. In Chitwan, neither temperature nor humidity varies much either throughout the day or incubation season. The range of incubation temperature varies between $24^{\circ} \mathrm{C}$ (minimum) and $43^{\circ} \mathrm{C}$ (maximum). However, the range of optimum incubation temperatures is considered to lie between $32^{\circ} \mathrm{C}$ and $34^{\circ} \mathrm{C}$, within which incubation time is reduced egg hatching success is greater. Singh and Bustard (in Whitaker and Basu 1983) gave a temperature range of $25^{\circ} \mathrm{C}$ to $37^{\circ} \mathrm{OC}$ for wild nests. Bustard (1978) demonstrated that $38^{\circ} \mathrm{C}$ was the highest temperature for incubating crocodile eggs; however, at $38^{\circ} \mathrm{C}$ the hatchlings were deformed and failed to emerge from the egg on their own.

Mean incubation period for the gharial nests in the Narayani and Kali rivers were $78 \pm 9$ days SD and $80 \pm 11.6$ days SD, respectively. The average incubation time during 1977 (94 \pm 5 days $S D$, range $=83-102$ days $)$ and 1978 (86 \pm 9 
days $S D$, range $=72-104$ days) were higher than for other years. During 1977 and 1978, eggs were incubated in a room heated by a kerosene heater within a temperature range of $32-34^{\circ} \mathrm{C}$. The room temperature was interrupted occasionally because of heater failure. Although the incubation periods were longer in 1977 and 1978, the mean hatching rate was relatively good $(47-75 \%)$.

The hatching success of crocodilians eggs under captive conditions was quite favorable. The mean hatching rates of eggs from the Narayani River varied from a low of $47.4 \%$ in 1978 to 75.18 in 1980. Joanen and McNease (1971) recorded a hatching success of $56 \%$ from naturally incubated eggs of American alligators. However, if eggs from wild-nesting alligators were collected soon after laying and incubated artificially, the hatching rate increased to $91 \%$ (Joanen and McNease 1987). Artificial hatching rates for various species of crocodiles have been reported to vary considerably (Yangprapakorn et al. 1971, Kimura 1976 and Suvanakorn et al. 1987). Percival and Jennings (1987) indicated that Alligator mississippiensis hatching rates appeared to vary among different wetlands in Florida.

Jacobson (1982) noted several disease syndromes that accounted for most of the mortality problems among hatchling gharials. The most common diseases noted with the hatchlings in Nepal were necrotizing skin disease and neurological disorders. Hatchlings, particularly during the 
monsoon season, develop small focal, white skin lesions that are particularly prominent around the cervical region and margin of jaws. Mycotic infection was responsible for more than $60 \%$ of hatchling mortalities at Chitwan. The second problem, neurological disorders, occurred in epidemic proportions in 1979 and 1981. The affected hatchlings lost body coordination and jerked uncontrollably. Mortality attributable to neurological disorders was $44.2 \%$ in 1979 $83 \%$ in 1981. To mitigate diseased-caused mortality of hatchlings, Jacobson (1982) recommended continuous flowthrough water systems to reduce the load of fecal material and detritus in the water.

singh and Bustard (1981) noted that eye defects of some kind occurred in eggs collected from the Kali and Narayani Rivers in Nepal. In this study, the complete absence of both eyes was recorded in two hatchlings from the same nest on the Kali River in 1979. Singh and Tandan (1978) reported the occurrence of blindness in a gharial population from the Girwa River, India, and attributed it to a deleterious gene. Among reptiles, growth of squamates and chelonians has been well studied (Fukada 1961, Wilbur 1975, Andrew 1976), but similar information on crocodiles is lacking. Growth curves for a number of species have been formulated from the growth of captive specimens (Cott 1961, Dowling and Brazaites 1966, Graham 1968). In this study, the rate of growth in weight and length of gharial hatchlings in 
captivity was greater in summer than in winter. Joanen and McNease (1977) have shown that growth rates in captive of American alligators can be doubled by optimizing temperature throughout the year. Another study on alligators by Chabreck and Joanen (1979) found a strong relationship between total length and both snout-vent length and weight. In alligators, growth rates of males and females do not differ until animals attain a total length of $1 \mathrm{~m}$, after which males grow more rapidly than females. Growth rates of hatchling gharials are greatest during mid-summer and less during the spring and fall. Webb et al. (1978) concluded that growth rate of $c$. porosus decreased as body size increased; males grew faster than females, and both sexes grew faster in the wet season than in the dry season. A comparative study by Krishnamurthy and Bhaskaran (1980) on c. porosus and $c$. palustris indicated that environmental factors play an important role in growth rates. of the two

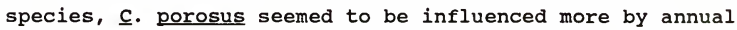

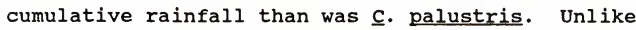
Crocodylus porosus, the growth rates of gharial hatchlings seemed to be influenced by temperature. Growth is (1) a product of food intake, which is in turn mediated by temperature, and (2) bioenergetic needs, also mediated by temperature. 
CHAPTER VII

REINTRODUCTION OF CAPTIVE-REARED

GHARIALS INTO THE NARAYANI RIVER

\section{Introduction}

Gharials, Gavialis gangeticus, were locally common during the 19th and early 20th centuries in the major rivers of the Indian sub-continent (Whitaker 1975, Singh 1978, Whitaker and Daniel 1978) and they were particularly abundant in northern India (Adam 1867). The gharial is now extinct or extremely depleted throughout its former range (Whitaker 1975, Bustard 1979, Mishra and Maskey 1981), largely because of habitat modification and disturbance, exploitation for the hide and other commercial products, and coincidental netting in fishing operations (Groombridge 1982). A captive-rearing program was started in 1974 (FAO 1974) to reestablish India's three species of crocodiles by collecting wild eggs, and, subsequently by rearing the young for restocking in selected, well protected natural habitats (Choudhury and Bustard 1981).

In Nepal, the Gharial Conservation Project was started in 1978 to increase gharial numbers in the Narayani and other major rivers of Nepal. A detailed survey of the Narayani River in 1980 (Maskey 1984) estimated a population 
of 53 adult wild gharials ( 7 males and 46 females) and no juveniles or hatchlings.

The Gharial Conservation Project released the first lot of 50 3-year-old animals into the Narayani River on March 2, 1981; subsequent releases were made in the Narayani River in 1982, 1983, 1984, and 1987, in the Kali River in 1983, in the Kosi River in 1983 and 1986 and the Rapti River in 1985 (Table 7-1). This project was designed to evaluate the efficacy of the release program in the Narayani River by surveying the river to monitor wild and released gharials; determining habitat use of wild and released gharials; and, determining survival and movements of released gharials.

\section{Methods}

Surveys of the Narayani River revealed two sites especially suitable for the release of captive-reared gharials (Fig. 2-2). These sites, considered to be optimum gharial habitat, were characterized by deep fast-flowing channels with relatively clear water, high banks and deep pools, and undisturbed sand banks at the river edge.

The captive-reared juveniles were maintained a minimum of 2 weeks in a temporary enclosure near the release site to prevent them from prematurely dispersing from the release 
Table 7-1. Number of gharials released in different river systems of Nepal, 1981-1987.

\begin{tabular}{|c|c|c|c|}
\hline Year & River & $\begin{array}{l}\text { Gharials } \\
\text { released }\end{array}$ & Remarks \\
\hline 1981 & Narayani & 50 & $\begin{array}{l}10 \text { animals were } \\
\text { fitted with radio } \\
\text { transmitters }\end{array}$ \\
\hline 1982 & Narayani & 50 & $\begin{array}{l}6 \text { animals were } \\
\text { fitted with radio } \\
\text { transmitters }\end{array}$ \\
\hline 1983 & Narayani & 25 & \\
\hline 1983 & $\mathrm{KaIi}$ & 35 & \\
\hline 1983 & Kosi & 42 & \\
\hline 1984 & Narayani & 15 & \\
\hline 1985 & Rapti & 5 & $\begin{array}{l}\text { Escaped from } \\
\text { captivity }\end{array}$ \\
\hline 1986 & Kosi & 42 & \\
\hline 1987 & Narayani & 43 & $\begin{array}{l}19 \text { animals were } \\
\text { fitted with radio } \\
\text { transmitters }\end{array}$ \\
\hline
\end{tabular}


area and being swept downstream by the current. The animals released during 1983 and 1984 were not maintained in a temporary enclosure, and they disappeared immediately from the release site. Releases were made in early February to allow adequate time for the captive-reared gharials to acclimate to the wild before the onset of the monsoon, and resultant floods, in June.

\section{Radio Attachment Trials}

Several techniques to attach radio transmitters to gharials were employed during the course of study. In 1981, 10 cylindrically shaped transmitters, weighing about $75 \mathrm{~g}$ each, were fitted by using nylon line to tie the transmitter to the animal via holes drilled in the two post occipital scutes. In addition to transmitters, the gharials were marked with prominent numbered, yellow plastic tags that were attached to the first single scute of the tail with a nut and bolt. After about 1 month, however, both the radio transmitters and tags had pulled out of their attachments.

In 1982, another four transmitters were tied, with nylon, between the scutes of the double crested region of the tail. This method of attachment, although proving serviceable for 3 months, was still judged unsatisfactory. Also in 1982, two transmitters were attached to animal by means of a canvas vest that had side openings for the fore limbs; it was secured on the ventral side by rivets. The 
animals with transmitter vests exhibited aberrant behavior; in fact, one of them died after only one day, presumably because of difficulty in breathing. In all of the above cases, there also was concern about the externally fitted transmitters impeding the movements of the animals particularly when in vegetation.

A transmitter implant was tested in Florida on four alligators $1 \mathrm{~m}$ in length. All animals survived for 1 year, and the transmitters functioned for the entire time. Animals whose surgery was performed by Dr. E. Jacobson, (School of Vet. Medicine, University of Florida) healed completely and exibited weight gains. Animals on which surgery was performed by untrained surgeons failed to heal properly; although the animal survived, they suffered from minor infections and either lost weight or did not grow appreciably during the year.

One-stage implantable transmitters (SB2-AVM Instrument Co., CA) were used for all animals released in 1987. Transmitters emitted 76-83 pulse signals per minute, had individually preset frequencies within the 150.021-151.399 MHz band, and had an estimated range up to $1 \mathrm{~km}$. Power was supplied by one 3.0v lithium battery which had an average current drain of .27 mA and life expectancy of 360 days. Each transmitter and battery was dipped in beeswax, and then covered with dental acrylic. The aerial, $30 \mathrm{~cm}$ in length, protruded from this impervious package. The complete 
transmitter package measured $5 \mathrm{~cm} \times 2.2 \mathrm{~cm}$ and weighed about $20 \mathrm{~g}$

Animals were immobilized within 15-20 minutes by enclosing the head inside a wide-mouth bottle in which halothane-(2-Bromo-2-chloro-1,1,1-trifluoroethane) soaked cotton balls were placed. The skin was prepared for surgery with betadine solution. A surgical incision about 7-8 cm long was made on the side of the body immediately forward of the left hind leg. The peritoneum was opened by an incision along the linea alba. Each transmitter, which had been sterilized in betadine solution for 24 hours, was placed ventrally in the abdomen. The $30-\mathrm{cm}$ antenna was passed dorso-laterally in a $28 \mathrm{~mm}$ hollow needle between skin and muscle over the hind leg and along the tail. The incision was closed with 2-0 surgical softgut. Surgical procedures were performed at the nursery by a local veterinarian. All animals also were marked with prominently numbered, yellow plastic tags that were attached by nylon line to the first two single scutes of the tail.

After the surgical implantation of the radio transmitters, the animals were maintained in the Chitwan nursery until the incision healed. The incisions generally healed within a week; the animals, however, were maintained under observation for at least 2 weeks prior to their transport to the release site. Forty-one animals were released on February 9, 1987, and two were released on March 
5, 1987 into the Narayani River release site 2 (Fig. 2-2). of the 43 released gharials, 20 were males, 13 were females and 10 were of unknown sex. The latter were very small in size $(100-120 \mathrm{~cm})$ and it was not possible to determine their sex.

\section{Tracking Method}

Seven radio-equipped gharials were monitored from February to August 1987, and one until December 1987. Six radios stopped transmitting immediately after implant (Table 7-2, Figure 7-1); and four ceased functioning within 30-40 days after release. These malfunctions were thought to be related to battery failure. The transmitter inplants did not appear to have any adverse effect on the animals.

Only diurnal monitoring was done because nocturnal fog prohibited visual sightings and complicated logistics. All animals were located daily by a local field assistant, and I personally located all animals three times a week. The position of tagged animals was determined by approaching at close range $(10 \mathrm{~m})$ and rotating the directional antenna until an arc of maximum audible signal was determined. Bisecting this arc indicated the direction to the animal. To facilitate the plotting of gharial locations, the river was divided into a series of $200 \mathrm{~m}$ sections, each of which was numbered with reference to the distance from the release 
point. Approximately $90 \%$ of all locations were obtained from dugout canoe and $10 \%$ on foot.

\section{Results}

Movements

The movement patterns exibited by 43 gharials released in February 1987 were quite variable with respect to both distances travelled and direction of movement (Figure 7-2). Three of the gharials released in February escaped from the enclosure after 24 hours by crawling $50 \mathrm{~m}$ over sand and rock banks to the main river channel. These animals were marked with visual marks but not radio transmitters. One remained $200 \mathrm{~m}$ downstream of the release site for 5 days and then disappeared; it was never seen again. Another moved immediately $800 \mathrm{~m}$ downstream, and by the end of June had moved $37.2 \mathrm{~km}$ ( $\mathrm{n}=18$ locations) downstream to within $4 \mathrm{~km}$ of the dam (Appendix E, E-1). The animal then disappeared after 10 days, possibly moving downstream of the dam into India. The third escapee remained near the release site for 6 days; it then traveled downstream but remained within about $10 \mathrm{~km}$ of the site through December (Appendix E, E-2) . During the first month (February) of release, the gharials dispersed upstream and downstream with nearly equal frequency; subsequently $81 \%$ (34) gradually moved downstream 
Table 7-2. Duration of functioning (in days) of radio transmitters inplanted in 19 gharials.

\begin{tabular}{|c|c|c|c|c|c|}
\hline $\begin{array}{l}\text { Animal } \\
\text { number }\end{array}$ & $\begin{array}{l}\text { Radio } \\
\text { frequency } \\
(\mathrm{mHz})\end{array}$ & $\begin{array}{l}\text { Assembly } \\
\text { date }\end{array}$ & $\underset{\text { implant }}{\text { date }}$ & $\begin{array}{l}\text { stop } \\
\text { transmitting } \\
\text { date }\end{array}$ & $\begin{array}{l}\text { Duration of } \\
\text { transmitter } \\
\text { in days }\end{array}$ \\
\hline 8701 * & 151.125 & 122486 & & & \\
\hline $8705 * *$ & 150.251 & 122486 & & & \\
\hline 8716 & 151.399 & 122486 & 011987 & 020587 & 44 \\
\hline 8718 & 151.324 & 122486 & 011987 & 020587 & 44 \\
\hline 8719 & 150.361 & 122486 & 011987 & 071087 & 198 \\
\hline 8720 & 150.399 & 122486 & 011987 & 022587 & 64 \\
\hline 8721 & 150.261 & 122486 & 011987 & 061587 & 173 \\
\hline 8722 * * * & 150.021 & 122486 & 011987 & & \\
\hline 8723 & 150.553 & 122486 & 011987 & 031487 & 81 \\
\hline 8725 & 150.962 & 122486 & 011987 & 080587 & 224 \\
\hline 8726 & 150.663 & 122486 & 011987 & 020887 & 47 \\
\hline 8727 & 150.735 & 122486 & 011987 & 020887 & 47 \\
\hline 8730 & 151.083 & 122486 & 011987 & 061287 & 169 \\
\hline 8736 & 150.432 & 122486 & 011987 & 030887 & 75 \\
\hline 8740 & 150.050 & 122486 & 011887 & 031587 & 81 \\
\hline 8741 & 150.335 & 122486 & 011887 & 032087 & 87 \\
\hline 8742 & 150.152 & 122486 & 011987 & 020887 & 47 \\
\hline 8743 & 150.230 & 122486 & 011987 & 091187 & 46 \\
\hline 8750 & 150.294 & 122486 & 011987 & 020887 & 47 \\
\hline $\begin{array}{ll}\star & \mathrm{Th} \\
\star \star & \mathrm{Th} \\
\star \star \star & \mathrm{Tr}\end{array}$ & $\begin{array}{l}\text { e animal } \mathrm{w} \\
\text { e animal } \mathrm{w} \\
\text { ansmitter }\end{array}$ & $\begin{array}{l}\text { is killed } \\
\text { las workin }\end{array}$ & $\begin{array}{l}\text { com the } r \\
\text { by adult } \\
\text { g till t }\end{array}$ & $\begin{array}{l}\text { Civer. } \\
\text { mugger. } \\
\text { the end of the }\end{array}$ & year \\
\hline
\end{tabular}




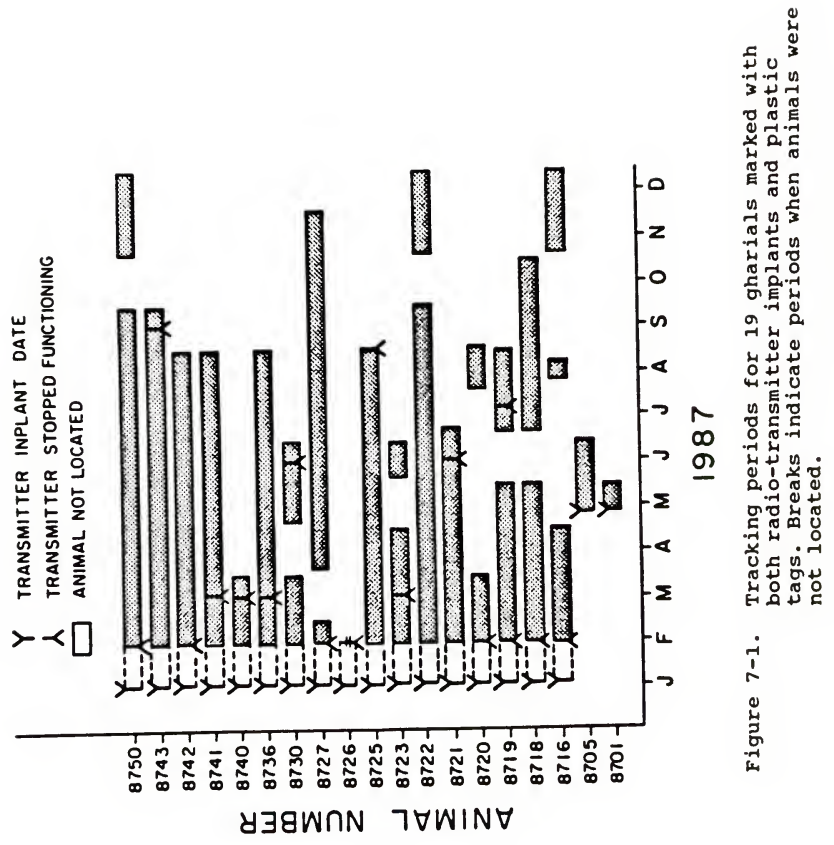




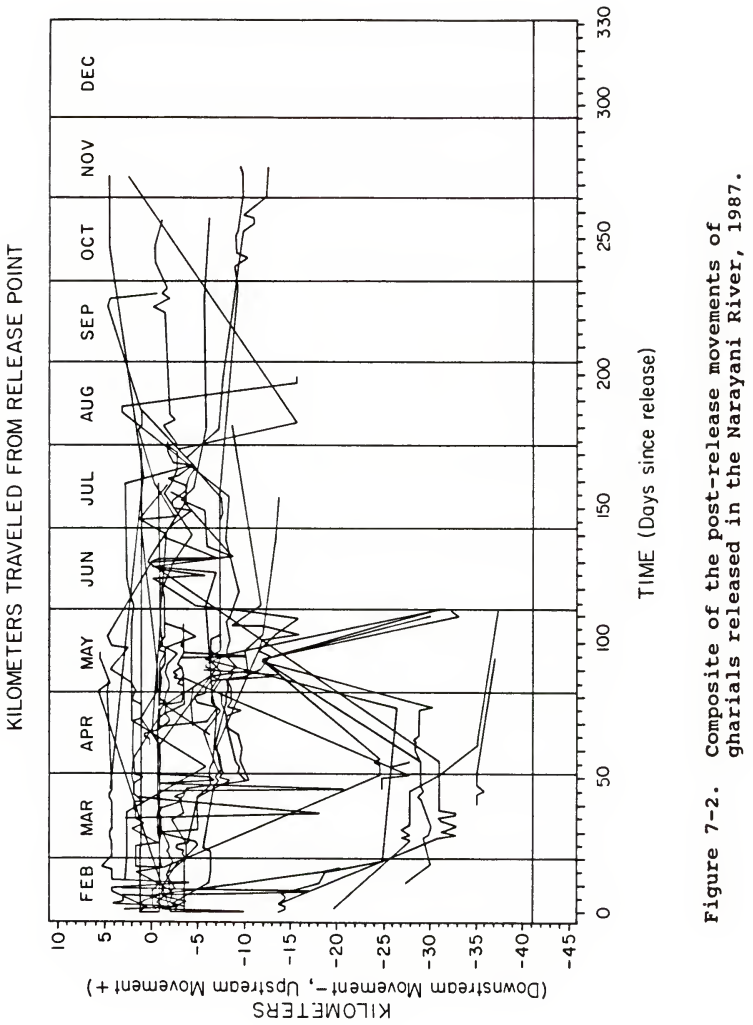


and 198 (8) upstream (Figure 7-3). During the summer (JuneAugust), $90 \%$ of the releases were sighted downstream and less than $10 \%$ were located upstream of the release site. This distribution could have been due to the effect of either the monsoon floods or animals moving to find small channels in search of better food resources. Similarly, wild gharials also moved into small channels of the river during the monsoon period. During the period following the monsoon season (September-December), four animals ( $9 \%$ ) were found upstream of the release site.

Two animals moved continuously downstream, travelling $2.8 \mathrm{~km}$ and $4.0 \mathrm{~km}$ in the first 20 days (February), and 0.8 and $27.0 \mathrm{~km}$ downstream in March; by June, they were $37.2 \mathrm{~km}$ and $37.6 \mathrm{~km}$ downstream of the release site. They were not located after the monsoon (Appendix E, E-1 and E-3), and were thought to have crossed the dam into India. (Note: In 1981, a gharial equipped with an externally mounted radio was reported in India about $200 \mathrm{~km}$ below the dam (Statesman 1981)).

About $23 \%$ ( $\mathrm{n}=11$ ) of the released gharials moved $<10$ $\mathrm{km}$ upstream or downstream of the release site (Appendix E, E-4 to E-13). One of these individuals, monitored for an entire year (Appendix E, E-14), stayed within $17 \mathrm{~km}$ of the release site. Another animal immediately moved $35 \mathrm{~km}$ downstream and stayed there during April; however, it moved $30 \mathrm{~km}$ upstream into the Gundrihi River (Appendix E, E-15). 


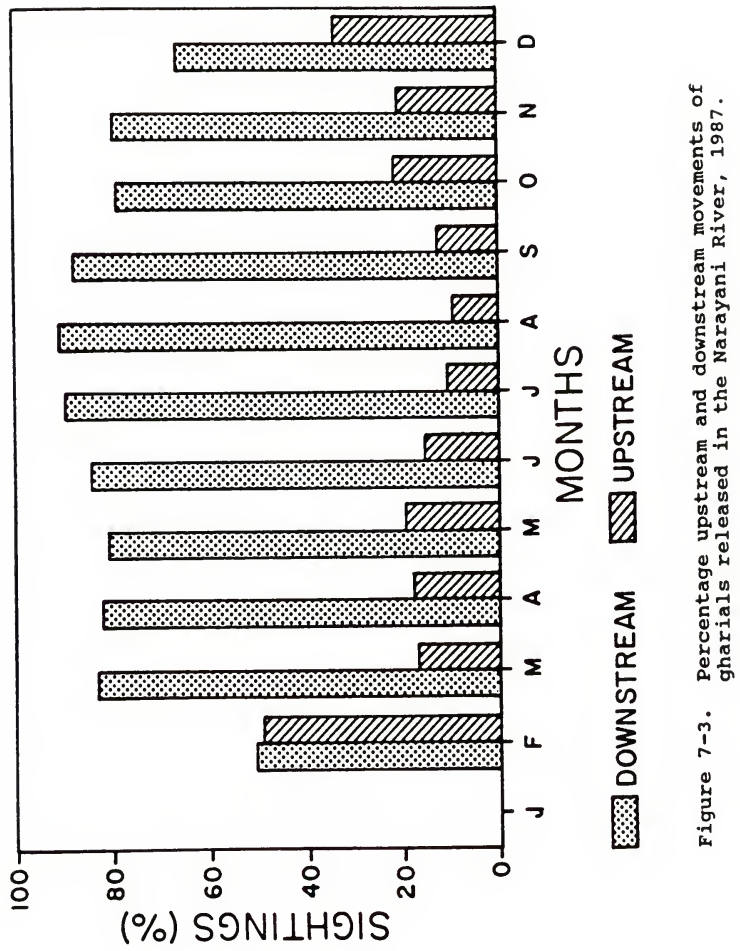




\section{3}

Three size classes of animals were released into the Narayani River in 1987: $30 \%(n=13)$ of the animals were in size class $1(100-120 \mathrm{~cm}) ; 28 \%(\mathrm{n}=12)$ in class $2(121-140$ $\mathrm{cm})$; and $42 \%(\mathrm{n}=18)$ in class 3 (141 cm and larger). More than half of size class 1 animals moved about $40 \mathrm{~km}$ downstream to the Velaungi area, which was within $8 \mathrm{~km}$ of the dam; none of the animals were located after the monsoons. Post-release movements of individual gharials indicated that smaller animals moved downstream at a greater dispersal rate than the larger size classes; differences in upstream/downstream movements of class 2 and class 3 animals were negligible.

Within 20 days post-release, two animals (classes 1 and 3) were located 14.8 and $14.4 \mathrm{~km}$ downstream, respectively. By March, the maximum distances traveled by four other (classes 1, 2 and 3) animals were 33.0, 30.2, 28.6, and 27.0 $\mathrm{km}$, respectively. By the end of December, only 12 animals (28\%), all classes 2 or 3 , from the 1987 releases were in the Narayani River.

Five animals had died during the study period (see survival p. 111); the remainder (about 58\%) of the missing animals were thought to have crossed the dam into India.

The mean upstream and downstream movements of released gharials during 1982 and 1987 did not differ significantly ( $t=0.48$, df $=42, P=0.63 ;$ and $t=-0.64$, df $=31, P=$ 0.56 , respectively), but there was a significant difference 
in the upstream and downstream movement among 1981 releases $(t=2.91, \mathrm{df}=48, \mathrm{P}=.005)$. However, there was a

significant difference in upstream and downstream movements by male and female gharials in the Narayani River $(t=0.71$, $\mathrm{df}=1, \mathrm{P}<.05 ;$ and $\mathrm{t}=0.96, \mathrm{df}=20, \mathrm{P}<.05$

respectively). The mean upstream and downstream movements of males were larger $(7.95,6.27 \mathrm{~km})$ than those of females $(0.73,3.13 \mathrm{~km})$. The final dispersal distances for the 1981 animals ranged from 1.6 to $13.2 \mathrm{~km}$ downstream and from 1.2 $\mathrm{km}$ to $5.0 \mathrm{~km}$ upstream of the release site.

The Kendall Tau correlation analysis indicates poor correlation between mean distance travelled and final dispersal distance for gharials released in 1987 and 1981. $\left(r^{2}=0.33, d f=31\right.$ and $r^{2}=0.32, d f=48$, respectively), but it was highly correlated for gharials released in 1982 $\left(r^{2}=0.55, d f=36\right)$.

\section{Habitat Use}

Five (sand banks, grass banks, sand-grass banks, rocky banks and river channel) of the six identified habitat types were used by both wild adult and released gharials in the Narayani River. Because none of the released or adult gharials were located on the eroded banks, this habitat type was not considered in calculating proportional use of habitats. Like wild gharials, released gharials used sand banks more frequently than any other type (Fig. 7-4), being 
observed in this habitat between 60 and $70 \%$ of the time in all three seasons. The second most commonly used (20-30\%) habitat was rocky banks. However, with respect to habitat availability, released gharials used sand banks and the river channel more than was expected and other habitats less than was expected in both winter and summer (Table 7-3 to 75) .

There was no significant difference in habitat use by male and female released gharials (Chi-square $=7.243, \mathrm{df}=$ 4, $\mathrm{p}=0.124)$ (Table 7-6). However, habitat use did differ with respect to the size of the released animals (Chi-square $=21.1, \mathrm{df}=8, \mathrm{P}=.007)$. Although habitat use by class 2 and class 3 animals was not different, habitat use by size class 1 individuals was different from classes 2 and 3 . (Table 7-7). The smaller gharials (class 1) used rock banks more frequently and sand banks less frequently than the large gharials (classes 2 and 3 ).

\section{Survival}

Five (12\%) of the 43 gharials released in the Narayani River in February 1987 had died by the end of the calender year. Three of these gharials were small (class 1) and were very sedentary at the time of release; two were found dead three days post-release, and one was presumably killed by an adult mugger at about 30 days post-release. One transmittered animal (class 2) was found dead of unknown 
causes 2 days post-release. The incision of this animal was examined and found to be completely healed. One gharial (class 2) was killed accidentally by a fisherman with a pole used to propel a fishing boat.

of the 218 gharials released in the Narayani and Kali rivers during 1981 to 1987,52 (24\%) had survived to December 1987 (Table 7-8). 


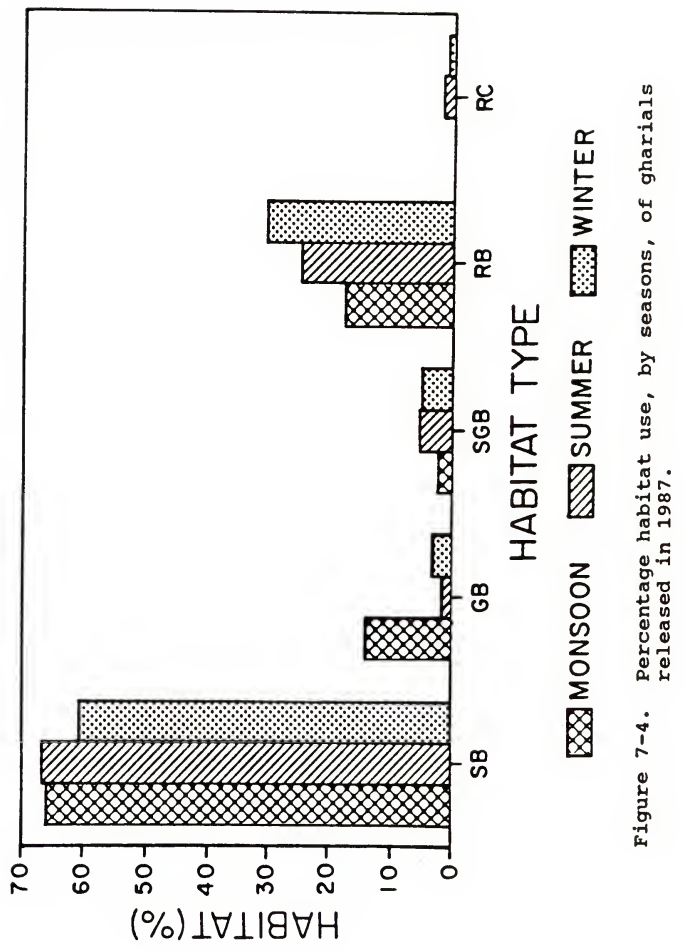


Table 7-3. Habitat use by gharials released into the Narayani River, 1981.

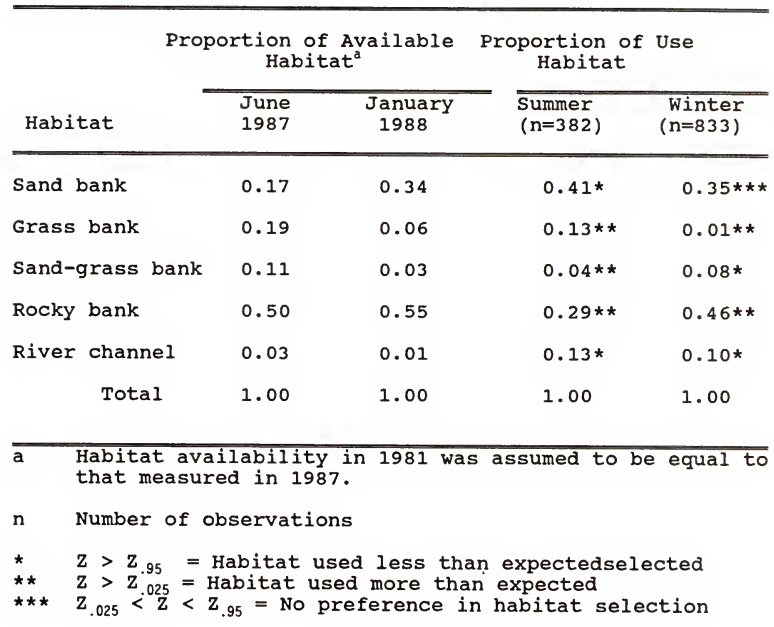


Table 7-4. Habitat use by gharials released into the Narayani River, 1982 .

\begin{tabular}{|c|c|c|c|c|}
\hline \multirow[b]{2}{*}{ Habitat } & \multicolumn{2}{|c|}{$\begin{array}{c}\text { Proportion of Available } \\
\text { Habitat }\end{array}$} & \multicolumn{2}{|c|}{$\begin{array}{c}\text { Proportion of Use } \\
\text { Habitat }\end{array}$} \\
\hline & $\begin{array}{l}\text { June } \\
1987\end{array}$ & $\begin{array}{c}\text { January } \\
1988\end{array}$ & $\begin{array}{l}\text { Summer } \\
(\mathrm{N}=357)\end{array}$ & $\begin{array}{l}\text { Winter } \\
(\mathrm{N}=534)\end{array}$ \\
\hline Sand bank & 0.17 & 0.34 & $0.47 *$ & $0.71 *$ \\
\hline Grass bank & 0.19 & 0.06 & $0.07 * *$ & $0.02 * \star$ \\
\hline Sand-grass bank & 0.11 & 0.03 & $0.11 * \star *$ & $0.01 * \star$ \\
\hline Rocky bank & 0.50 & 0.55 & $0.03 * \star$ & $0.04 * *$ \\
\hline River channel & 0.03 & 0.01 & 0.32 * & $0.22 *$ \\
\hline Total & 1.00 & 1.00 & 1.00 & 1.00 \\
\hline
\end{tabular}

a Habitat availability in 1981 was assumed to be equal to that measured in 1987.

n Number of observations

* $\quad \mathrm{Z}>\mathrm{Z} .95 \quad$ = Habitat used less than expectedselected

$\star \star \quad \mathrm{Z}>\mathrm{Z}_{.025}=$ Habitat used more than expected

$\star \star \star \quad \mathrm{Z}_{.025}<\mathrm{Z}<\mathrm{Z}_{.95}=$ No preference in habitat selection 
Table 7-5. Habitat use by gharials released into the Narayani River, 1987.

Proportion of Available Proportion of Use Habitat Habitat

\begin{tabular}{|c|c|c|c|c|}
\hline \multirow[b]{2}{*}{ Habitat } & \multirow[b]{2}{*}{$\begin{array}{l}\text { June } \\
1987\end{array}$} & \multirow[b]{2}{*}{$\begin{array}{c}\text { January } \\
1988\end{array}$} & \multirow[b]{2}{*}{$\begin{array}{l}\text { Summer } \\
(N=443)\end{array}$} & \multirow[b]{2}{*}{$\begin{array}{l}\text { Winter } \\
(\mathrm{N}=1031)\end{array}$} \\
\hline & & & & \\
\hline Sand bank & 0.17 & 0.34 & $0.65 *$ & $0.57 \star$ \\
\hline Grass bank & 0.19 & 0.06 & $0.07 * *$ & $0.02 * \star$ \\
\hline Sand-grass bank & 0.11 & 0.03 & $0.04 * \star$ & $0.06 *$ \\
\hline Rocky bank & 0.50 & 0.55 & $0.20 * \star$ & $0.27 \star \star$ \\
\hline River channel & 0.03 & 0.01 & $0.04 \star \star \star$ & $0.08 *$ \\
\hline Total & 1.00 & 1.00 & 1.00 & 1.00 \\
\hline
\end{tabular}

$\mathrm{n}$ Number of observations

* $\quad \mathrm{Z}>\mathrm{Z} .95 \quad=$ Habitat used less than expectedselected

$\star \star \quad \mathrm{Z}>\mathrm{Z}_{.025}=$ Habitat used more than expected

$\star \star * \quad \mathrm{Z}_{.025}<\mathrm{Z}<\mathrm{Z}_{.95}=$ No preference in habitat selection 
Table 7-6. Percentage use of habitats by male and female released gharials, 1987.

\begin{tabular}{lcccccc}
\hline & \multicolumn{5}{c}{ Percentage Use by Habitat Type } \\
\cline { 3 - 7 } Sex & $\begin{array}{c}\text { No. of } \\
\text { obs. }\end{array}$ & $\begin{array}{c}\text { Sand } \\
\text { bank } \\
(25 \%)\end{array}$ & $\begin{array}{c}\text { Grass } \\
\text { bank } \\
(13 \%)\end{array}$ & $\begin{array}{c}\text { Sand-grass Rocky } \\
\text { bank } \\
(7 \%)\end{array}$ & $\begin{array}{c}\text { River } \\
\text { bank } \\
\text { bank } \\
(53 \%)\end{array}$ \\
\hline Male & 481 & $62.8 *$ & $3.3 * *$ & $3.5 * *$ & $29.3 * *$ & $1.1 * *$ \\
Female & 432 & $66.6 *$ & $4.2 * *$ & $4.2 * *$ & $25.0 * *$ & $0.0 * *$ \\
\hline
\end{tabular}

a Percentage of available habitat in the Narayani River

* $\quad \mathrm{Z}>\mathrm{Z} .95 \quad=$ Habitat used less than expectedselected

$\star \star \quad \mathrm{Z}>\mathrm{Z}_{.025}=$ Habitat used more than expected 
Table 7-7. Percentage use of habitats by size class 1, 2, and 3 released gharials, 1987.

\begin{tabular}{|c|c|c|c|c|c|c|c|}
\hline \multirow[b]{2}{*}{$\begin{array}{l}\text { Size } \\
\text { class }\end{array}$} & \multirow[b]{2}{*}{$\begin{array}{l}\text { No: of } \\
\text { animals }\end{array}$} & \multirow[b]{2}{*}{$\begin{array}{l}\text { No. of } \\
\text { obs. }\end{array}$} & \multicolumn{5}{|c|}{ Percentage Use by Habitat Type } \\
\hline & & & $\begin{array}{l}\text { Sand } \\
\text { bank } \\
(25 \%)^{a}\end{array}$ & $\begin{array}{l}\text { Grass } \\
\text { bank } \\
(13 \%)\end{array}$ & $\begin{array}{c}\text { Sand-grass } \\
\text { bank } \\
\left(\begin{array}{ll}7 & \%\end{array}\right)\end{array}$ & $\begin{array}{l}\text { Rock } \\
\text { bank } \\
(53 \%)\end{array}$ & $\begin{array}{l}\text { River } \\
\text { bank } \\
(2 \%)\end{array}$ \\
\hline $\begin{array}{c}1 \\
(100-120 \mathrm{~cm})\end{array}$ & 13 & 392 & $55.9 *$ & $3 \cdot 3 \star \star$ & $7.6 * \star \star$ & $32.9 * \star$ & $0.3 * *$ \\
\hline $\begin{array}{c}2 \\
(121-140 \mathrm{~cm})\end{array}$ & 12 & 351 & $65 \cdot 2 *$ & $3.1 * \star$ & $4 \cdot 8 \star \star$ & $25.9 * *$ & $0.9 * *$ \\
\hline $\begin{array}{l}3 \\
(\geq 141 \mathrm{~cm})\end{array}$ & 18 & 562 & $67.8 *$ & $3 \cdot 9 * \star$ & $4 \cdot 3 * \star$ & $23.8 * \star$ & $0.2 * \star$ \\
\hline
\end{tabular}

a Percentage of available habitat in the Narayani River

* $\quad \mathrm{Z}>\mathrm{Z} .95 \quad=$ Habitat used less than expectedselected

$\star * \quad \mathrm{Z}>\mathrm{Z}_{.025}=$ Habitat used more than expected

$\star * * \mathrm{Z}_{.025}<\mathrm{Z}<\mathrm{Z}_{.95}=$ No preference in habitat selection 
Table 7-8. Survival rate of the released gharials 1981-1988.

\begin{tabular}{|c|c|c|c|c|c|c|c|c|}
\hline \multirow[b]{2}{*}{ Year } & \multirow{2}{*}{$\begin{array}{l}\text { No: of } \\
\text { animals } \\
\text { released }\end{array}$} & \multicolumn{2}{|c|}{ Percentage } & \multicolumn{4}{|c|}{$\begin{array}{l}\text { of gharials sighted } \\
\text { following release }\end{array}$} & \multirow{2}{*}{$\begin{array}{c}\text { years } \\
\begin{array}{c}\text { Year } \\
7\end{array}\end{array}$} \\
\hline & & $\begin{array}{c}\text { Year } \\
1\end{array}$ & $\begin{array}{c}\text { Year } \\
2\end{array}$ & $\begin{array}{l}\text { Year } \\
3\end{array}$ & $\begin{array}{c}\text { Year } \\
4\end{array}$ & $\begin{array}{l}\text { Year } \\
5\end{array}$ & $\begin{array}{c}\text { Year } \\
6\end{array}$ & \\
\hline 1981 & 50 & 68 & 60 & 60 & 58 & 36 & 30 & 22 \\
\hline 1982 & 50 & 64 & 58 & 58 & 40 & 36 & 24 & \\
\hline 1983 & 60 & 42 & 45 & 45 & 30 & 12 & & \\
\hline 1987 & 43 & 28 & & & & & & \\
\hline
\end{tabular}




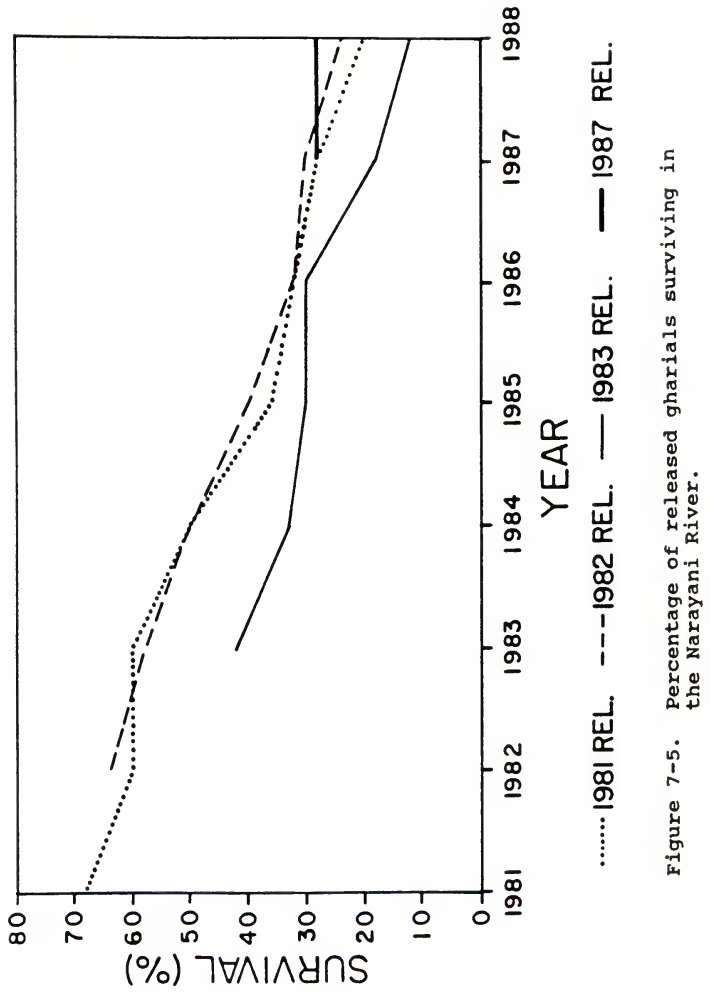




\section{Discussion}

The successful reintroduction of released gharials in the wild is dependent initially upon selection of a suitable release site and acclimation of releases to the wild. The animals released in 1983 and 1984 were not maintained in acclimation enclosures prior to release and they moved greater distances and exibited lower survival than those maintained in enclosures. Released gharials must be afforded every opportunity to acclimate to natural conditions; thus the release site should be located in optimum habitat, i.e., deep, fast flowing and relatively clear water that adjoin high sand banks. They also should be maintained in a temporary enclosure adjacent to the main river channel for 1 to 2 weeks prior to release.

The season of release also constitutes an important consideration in the release program. The best release time was between the last week of January and the first week of February giving the releases at least four months to adjust to the wild before commencement of the monsoon in mid-June. Choudhury and Bustard (1981) also suggested early spring release of captive reared muggers for the same reason.

In comparison to the movement of released gharial in India (Singh and Bustard 1983), where some individuals moved $25 \mathrm{~km}$ in 15 days, $95 \mathrm{~km}$ in 1 month and $150 \mathrm{~km}$ in about 2 months, the gharials released into the Narayani were 
relatively sedentary. Typically, they had dispersed $15 \mathrm{~km}$ downstream within the first 20 days, $33 \mathrm{~km}$ by the second month, $35 \mathrm{~km}$ by the fourth month, and $37 \mathrm{~km}$ by the fifth month. In this study, gharial movement was limited by the dam at the Indo-Nepalese border, located $42 \mathrm{~km}$ downstream of the release site. Animals crossing the dam could not be monitored because of the logistical and political problems in working on the Indian side of the border. Some of the released gharials undoubtedly crossed the dam; they could not return because the dam impeded their upstream movement. Some of these "beyond-the-dam" dispersers probably survived. Although the loss of these animals diminished the effectiveness of the Nepali program per se the overall effectiveness of the program to conserve this endangered crocodile was enhanced--political boundaries not withstanding.

More animals (23\%) of the larger size classes (2 and 3 ) moved upstream from the release site than of the smaller size class ( $8 \%$ ). Only one animal from size class 1 moved upstream, but about $80 \%$ presumably moved downstream of the dam. Of the 26 animals from size classes 2 and 3 , only four moved downstream of the dam and most of them stayed within $10 \mathrm{~km}$ downstream of the release site.

In 1987,115 hatchlings were released into the Narayani River near the hatchery site. None was located after 10 
days post-release. They probably were carried away by the high monsoon flood.

Choudhury and Bustard (1981) stated that survival rates of released muggers could be increased through the release of 1.0-1.2 m sized animals because animals of $<1.2 \mathrm{~m}$ in length had not been observed digging burrows, a behavior necessary for winter survival. However, Singh (1981) reported that two, 6-month old escaped muggers (56.9 and $54.3 \mathrm{~cm}$ in length) successfully survived in the natural environment.

Movements and survival rates of released animals are related to disturbances at the release site. Low survival (1\%) and increased dispersal (150 km in 2 months) of released gharials in India were attributed to heavy fishing activities and bamboo rafting in the release area (Singh et al. 1983). In contrast, three gharials released into the Chambal River in 1977, when there was no disturbance, moved only $1.3 \mathrm{~km}$ in a 6 month period (Bustard 1982). He also believed that permanent high water and associated side creeks due to a dam downstream, provided favorable release conditions at this site. The latter observation obviously is not in concert with the findings from this investigation. Side creeks and tributaries of the Narayani River provided habitat for both wild adults and released gharials. Every year during the monsoon, most of the wild adults of both sexes as well as the captive-reared gharials released 
in 1981 and 1982 moved upstream into the Rapti River, about $50 \mathrm{~km}$ upstream of the Rapti-Narayani confluence (Fig. 2-2). They remained there until september and began moving back to the Narayani by late september. Similarly, ten animals released in 1987 were located about $6 \mathrm{~km}$ upstream of the Gundrihi River, a Narayani tributary, during the monsoon. Both wild adult and released gharials tended to return to their pre-monsoon localities after the monsoon. Bustard and Singh (1983) suggested that the movement of gharials into side streams during floods may be associated with similar movements of their fish prey. During these high floods both fish and gharial probably enter small side streams to avoid the force of water flow in the main river.

There is a significant difference in upstream and downstream movements by male and female released gharials in the Narayani River. Webb and Messels (1978) found that the pattern of movement of crocodylus porosus in Northern Australia differed between sexes and areas. They suggested that differences in patterns of movement between areas might be due to formation of creches (aggregation of hatchling crocodiles accompanied by a parent) or to differences in river current. Similarly, Bustard and Singh (1983), studying the movement of four adult gharials found that males made long range movements up to $44.4 \mathrm{~km}$, although their home ranges were considered to have been much smaller. They suggested that these extensive movements may be related 
to the absence of other gharials in the river; male gharials are territorial and would be expected to restrict movements of other males in the river.

Adult and 1987 released gharials used sand banks more frequently than any other habitat in both winter and summer. Smaller size gharials used rocky banks more than the larger animals. The increased use of rocky banks by smaller animals may be associated with their comparative inexperience in the wild. The rocky banks also provide extra heat as well as protection to predators. The small animals basking on the sand banks are more vulnerable to the predators than those bask on the rock banks. As they mature they choose sand banks more frequently, suggesting that released gharials eventually choose the same habitat types as wild adult gharials. Because smaller animals have been observed together with larger ones without conflict, intraspecific competition for basking sites does not seem to be an issue here.

The survival rates of the animals released in 1981 and 1982 were higher than those released in 1983 and 1987 (Fig. 7-5). The gharials released in 1981 and 1982 were comparatively larger in size than the one released in 1983 and 1987. Because of the release of large size gharials, more animals from 1981 and 1982 releases presumably survived in the Narayani River. The gharials released in 1983 and 1984 were not kept in a temporary enclosure to prevent them 
from prematurely dispersing from the release site, resulting in a large proportion of the gharials being swept downstream by the river current. Similarly, a large proportion of the gharials released in 1987 were small in size, and more than $80 \%$ of them being swept downstream of the dam. There were no any catastrophic floods recorded since 1981, that does not seem to be aneffect here.

The Gharial Conservation Project of His Majesty's Government of Nepal has met with some success. The continued success of the project will depend on releases of gharials only > 1.2 meters; selection of appropriate release sites; and releases made in the first week of February. 
CHAPTER VIII

CONSERVATION STRATEGY FOR GHARIAL IN NEPALN

\section{Conservation strategy}

The survival of the gharial in India and Nepal is threatened primarily by continuous habitat destruction which is related to increasing human pressure on the environment due to extensive agriculture, firewood collection, cattle grazing, grass cutting, and heavy traffic in the river course. Secondly, commercial values of skins, meat, eggs and other parts have contributed to its decline (Whitaker and Daniel 1978). Before the establishment of the Royal Chitwan National Park, in 1973, both $\underline{\mathrm{G}}$. gangeticus and $\underline{\mathrm{c}}$. palustris could be hunted with a Department of Forest game license costing a nominal Rs. 200 (about US $\$ 10.00$ ) per animal. Both species were listed as Endangered under the National Park and Wildlife Conservation Act of 1973 and were later listed under Appendix I of CITES (Convention on International Trade in Endangered Species).

Whitaker (1987) and Singh (1987) reported that the same situation occurred in India until enforcement of their Wildlife Protection Act (1972), which listed all three

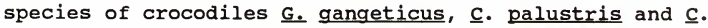


porosus (the latter does not occur in Nepal) on Schedule I of the Act. Prior to 1972, all three species of crocodiles could be hunted with a nominal game license (Whitaker 1987). While legal protection was provided it was not strongly enforced. As a result, the wild population of all three species in India were depleted to the verge of extinction (Singh et al. 1984). The actual conservation program for crocodilians commenced in 1974, when crocodilian populations already had become endangered and most remaining crocodilian habitats were threatened (Singh 1987, Biswas 1970a and b, Honneger 1971, Daniel and Hussain 1973 and Whitaker 1974).

A combination of protection, public education, human population control, and management of the animal is required to ensure the continued survival of gharials in the river systems of Nepal. In cases where strict protection and the removal of deleterious influences appear inadequate to save the surviving population of crocodilians, re-introduction or re-stocking may be an appropriate method to improve the distribution of a species (Sale 1986).

Through the effort of FAO/ UNDP and the Government of India, the gharials in India increased from 250 in 1974 to over 2500 in 1984 (Whitaker 1987 and singh et al. 1984) by re-stocking captive-reared animals into various river systems. By 1985, at least 34 rearing stations had been established in the country (Singh 1987). In addition, 34 different protected areas and sanctuaries (20399 $\mathrm{km}^{2}$ ) has 
been established to provide wild crocodilians with protected habitat. Of these 34 protected areas, $13\left(8346 \mathrm{~km}^{2}\right)$ were created specially for crocodile protection (Singh, et al. 1984). Singh (1987) and Whitaker (1987) also suggested that future Indian crocodilian conservation efforts should include public education and management of crocodilians as sustainable economic resources for the local people living around the crocodilian's habitat. The idea of value-added conservation (Hines and Percival 1987) has been expressed for the American alligators as well as for other species of crocodiles.

In Nepal, the Gharial Conservation Project was started in 1978 aided by the Frankfurt Zoological Society. Gharial in the Narayani and Kali rivers have increased from 53 in 1981 to about 90 in 1987 by re-stocking captive-reared gharials into the rivers. Since 1981, the Gharial Conservation Project adopted several strategies which operated simultaneously in the Royal Chitwan National Park. They included updating the status of wild gharial in Nepal, identifying suitable habitat for re-introduction and protection, collection of wild eggs from the Kali and Narayani rivers for hatchery incubation and rearing at Kasara, reintroduction of captive-reared stock, and longterm monitoring of the effectiveness of reintroduction. The project also has provided eggs and live animals to a variety of zoos and crocodile rearing centres in Japan and 
the United States for captive breeding programs. As the gharial is very specialized in its breeding habitat requirements, it is very difficult to breed in captivity. Captive breeding was first observed in the Nandankanan Biological Park, Orissa, India in 1980 (Singh et al. 1984). Captive breeding also has been tried unsuccessfully at Kasara.

The Nepal Gharial Conservation Project has successfully produced over 1500 gharials and reintroduced 307 into the Narayani, Kali and Kosi rivers. The project has concentrated in the Narayani River, a small proportion of the gharial's former range in Nepal which once also included in the Karnali, Babai, Rapti and Kosi rivers. Although some releases were made in the Kali and Kosi rivers, no data were collected on their survival and distribution nor proper surveys have been conducted to determine the status of the gharial in the Karnali, Babai, Rapti and Kosi rivers. It obviously is wise to distribute the gharial population among different river systems in the event that a catastrophe occurs in the Narayani. Until now, budgets and extreme logistical difficulties have prevented the development of an expanded program that would allow restocking and monitoring of gharials in other suitable areas. 


\section{Recommendations}

Based on the 10-year experience of the Gharial Conservation Project in the Royal Chitwan National Park, certain guidelines should be followed in the continuation and expansion of the project. Neglecting certain principles may result in failure, frustation, and wasted resources. The following recommendations are submitted:

1 The survey counts made in summer (May) and winter (January) indicated that winter counts provided higher numbers because of low water conditions and increased basking and were considered more reliable. It is recommended that a survey of existing wild populations and released gharials in each suitable river of Nepal should be conducted annually in winter (December to February) to maintain and update the status of the species.

2 All important habitats for the gharial should be identified and, if not within a National Park or Wildlife Reserve, declared as special Gharial Reserves. The Kali and Babai rivers should be declared as Special Gharial Reserves as soon as possible. The existing gharial populations there are eminently endangered because of continued poaching and habitat disturbance. 
3 In some stretches of the Narayani River, the local fishing contractors recently have used nets which extend entirely across the river. This type of fishing was stopped in 1974 by the park authorities, but were reinstated by the district administration in 1986. For the protection of the gharial as well as other valuable aquatic and fish resources, such large scale fishing activities should be stopped in the Narayani River as well as other rivers where suitable habitat reintroduction has been identified. A proposed regulation would be to allow fishing only by the Botes who belong to the permanent families of fishermen residing near the river. Fishing by free permit would be restricted to floating baits and throw nets. Permit renewal every three months would provide a check on the conduct of the fishermen.

4 The absence of juveniles in the Narayani and Kali rivers prior to the release program indicated that no recruitment of young gharials had occurred in the wild. Apparently, the combination of unsuccessful hatching, egg poaching and young being carried downstream by monsoon floods has prevented recruitment. It is recommended to collect and artificially incubate gharial eggs to 
avoid natural losses of eggs and hatchlings. However, in the future, some nests which appear safe from flooding will be left undisturbed to evaluate hatching success and survival of wild hatchlings. Data from gharials released in 1981, 1982, 1983, 1984, and 1987 indicated that largeer animals (> $1.2 \mathrm{~m}$ in length) showed higher probability of survival than the smaller ones. More than $80 \%$ of the smaller gharials released in the rivers were swept by the monsoon flood. Larger gharials (> $1.2 \mathrm{~m}$ in length) must be released in future to improve the success of the release program. Hatching success is dependent upon careful handling of the eggs. Nests should be opened in either early morning or late afternoon; original orientation of the eggs should be maintained by marking the top of each egg away from the white egg band avoiding any toxic effect to the embryo; collected eggs should be transported rapidly, avoiding vibrations and shock, in a strong box with sufficient sand to maintain constant incubating temperature and humidity during transport.

7 The incubating pits should be dug above the high water mark and not be subjected to strong ground 
vibration. A predator proof fence as well as guards should be provided to protect eggs from predators and humans. Each clutch should be planted in the hatchery in exactly the same manner as it occurred in the natural nest. Ambient and nest temperatures should be regularly monitored. Hatchlings should be transported to the rearing station directly after hatching.

8 Re-introduction sites should be chosen in protected areas within the known geographical range of the species. The habitat should meet basic requirements for food, basking, nesting, and proper water depth and flow. It also should be free from detrimental human disturbances such as fishing, poaching of eggs, illegal hunting, and habitat destruction.

9 Because of the presence of the dam at Tribenighat, $42 \mathrm{~km}$ downstream of the release site, the water depth in the river will perhaps never again become ideal gharial habitat. The location of the present release site has restricted the use of available habitat in the northern channel of the SIKH. The movement results also indicated that most of the released gharials tended to move downstream reaching the dam area faster. Therefore it is recommended that the future 
release site in the Narayani River be shifted 45 km upstream near sikrauli. The released animals could utilize suitable habitat both in the northern and southern channels of the SIKH sector and movement of gharials towards the dam area will be reduced.

10 Gharial should be fed only live fish for at least one month prior to their release to acclimate them to wild conditions. Buffalo or chicken meat is the recommended diet for captive animals.

11 The absence of juvenile gharials in the Kali River indicates that recruitment of wild animals has totally failed in this river, presumably because of fast flowing water currents that swept them to the Narayani River. However, animals released at the upper end of the river systems (Bhateri) may allow them to establish in the area prior to being washed down to the Narayani River.

12 Experience in the Narayani River has been that gharials should be maintained for 2 weeks prior to release in a temporary enclosure adjacent to the release site to acclimate them to the wild.

13 Re-introduction into Nepal should be from Nepali stock as long as they are available. To avoid the potential of contaminating gene pools, the closest available stocks should be used for re- 
introduction and mixing of stocks should not be allowed.

14 All released animals should be tagged and measured prior to release to assist in better estimates of survival, mobility, growth rate.

15 Regular long-term monitoring of released animals is vital for measuring such factors as distribution in relation to food, water depth, sand banks, survival, and movement patterns. Only by regular monitoring can the effectiveness of a re-introduction be assessed and to allow appropriate, timely action to be applied to problems detected. Inadequate, long-term monitoring appears to have been responsible for the ultimate failure of the re-introductions in the Kali and Kosi river systems.

Besides these guidelines, public education is an essential component of a gharial rehabilitation program in Nepal. People residing near the Narayani River should not consider the gharial to be an animal which conflicts with local interests. The mugger has had a bad reputation for attacking livestock but the local people fail to distinguish gharials from muggers. For example, one of the 1981 released gharials was known to have been killed by a villager who admitted to killing the animal because he 
thought it was a mugger. Even then, a nuisance control program will relieve impacts on the mugger.

The local people must be educated by circulating brochures, pamphlets and posters on the ecology of both animals and the values of the crocodiles in the ecosystem. The interest of the people in the project also could be improved through educational talks. Local people should be employed not only for the jobs of collecting, rearing, and monitoring of the animal, but to educate their people about the objectives of the Gharial Conservation Project.

The lessons and experiences gained from reintroducing gharial in the Narayani River could be utilized to protect other reptile species of Nepal. For example, four species of freshwater turtles were recorded in the Narayani River of the Royal Chitwan National Park in 1987. Only 25 Trionyx gangeticus, 5 Chitra indica, 6 Kachuga dhongoka and 2 Melanochelys tricarinata were recorded during the 6-month study period. These species also need immediate attention to protect them from extinction. A program similar to that for the gharial is needed to re-establish healthy populations of these species in the river. In conjunction with management programs, much needed biological data could be gathered on these species. 


\section{Future program}

The overall goal of the present Gharial Conservation Project in Nepal is to double the breeding population of gharial in the Narayani River and maintain the self sufficient population in all three major river systems of Nepal (Kosi, Narayani, and Karnali). At present the Narayani and Kali rivers are the only rivers that are providing eggs to supplement the animals in the Narayani, Kosi and Karnali rivers.

Because of the presence of the Tribeni dam in the Narayani River and the Kosi dam in the Kosi River, the water depth in the river will perhaps never again become ideal to allow the natural production of the gharial. Not a single juvenile gharial has been observed in these rivers prior to the release of captive-reared gharials. Any wild hatchlings produced were probably swept away by the monsoon flood, eliminating natural recruitment in these rivers. The presence of dams allows downstream but obstructs upstream movement of the gharials. The only survivors in the monsoon floods are the larger gharials that could avoid the floods by moving into tributaries of the rivers. Self sustaining populations in these rivers probably will not be successful without effective fish ladders that gharials could use. However, the river can be very effectively restocked to build up the gharial population of the river systems. 
The nests that are vulnerable to flooding should be collected and incubated every year to supplement these populations, however, some nests that are not as vulnerable to flooding will be left to investigate the hatching success in wild and hatchling survival in wild.

Altogether 218 hatchlings have been released in the Narayani and Kali rivers in the five year period and 52 (23.8\%) of them are still surviving in the Narayani River. If the present trend continues and the habitat quality does not deteriorate, the breeding population of the Narayani gharial will be doubled by 1995 . 


\section{APPENDIX A \\ CHECKLIST OF MAMMALS OF ROYAL CHITWAN \\ NATIONAL PARK}

(Bolton, 1975; Laurie, 1978, Sunquist, 1979)

Scientific Name

INSECTIVORA

Sunkus murinus

Tupaia glis

PRIMATES

Macaca mulatta

Presbytis entellus

\section{CARNIVORA}

Canis aureus

Cuon alpinus

Vulpes bengalensis

Melursus ursinus

Selenarctos thibetanus

Lutra perspicillata

Martes flavigula

Prionodon pardicolor

Viverra zibetha

Paradoxurus hermaphroditus

Herpestes edwardsi

Herpestes urva

Hyaena hyaena

Felis chaus

Felis viverrina

Felis bengalensis

Panthera pardus

panthera tigris

\section{CETACEA}

Platanista gangetica

PROBOSCIDAE

Elephas maximus
Common Name

Grey musk shrew

Malay tree shrew

Rhesus monkey

Common langur

Jackal

Indian wild dog

Indian fox

sloth bear

Himalayan black bear

Smooth Indian otter

Yellow throated martin

spotted linsang

Large Indian civet

common palm civet

Common mongoose

Crab eating mongoose

striped hyana

Jungle cat

Fishing cat

Leopard cat

Leopard

Tiger

Gangetic dolphin

Elephant 
PERISSODACTYLA

Rhinoceros unicornis

\section{ARTIODACTYLA}

Bos gaurus

Sus scrofa

Muntiacus muntjak

cervus porcinus

Cervus axis

Cervus unicolor

Tetracerus quadricornis

RODENTIA

Funambulus pennanti

Petaurista petaurista

Bandicota bengalensis

Hysrix indica

Rattus rattus

LAGOMORPHA

Lepus nigricollis

PHOLIDOTA

Manis crassicaudata
Great one-horned

rhinoceros

Gaur

Wild boar

Barking deer

Hog deer

Chital

Sambar

Four horned antelope

Five striped palm squirrel

Large flying squirrel

Indian mole rat

Indian porcupine

House rat

Indian hare

Pangolin 
APPENDIX B

CHECKLIST OF THE AMPHIBIANS AND REPTILES

OF ROYAL CHITWAN NATIONAL PARK

(Mitchell and Zug, 1986)

Scientific Name

AMPHIBIA

Salientia (Frogs)

Bufo melanostictus

Bufo stomaticus

Polypedates maculatus

Rana crassa

Rana cyanophlyctis

Rana danieli

Rana limocharis

Rana pierrei

Rana syhadrensis

Rana tigrina

REPTILIA

Crocodilia (Crocodilians)

Crocodylus palustris

Gavialis gangeticus

Testudines (Turtles)

Chitra indica

Inodotestudo elongata

Kachuga dhongoka

Kachuga kachuga

Melanochelys tricarinata

Trionyx gangeticus

Sauria (Lizards)

Calotes versicolor

Hemidactylus brookii

Hemidactylus flaviviridis

Mabuya dissimilis

Mabuya macularia 
Scincella sikimmensis

Varanus flavescens

Serpentes (Non venomous snakes)

Ahaetulla nasuta

Amphiesma stolata

Bioga ochracea

Boiga trigonata

Chrysopelea ornata

Dendrelaphis tristis

Elachistodon westermanni

Elaphe helenae

Elaphe radiata

Homalopsis buccata

Lycodon aulicus

oiigodon arnensis

Psammophis condanarus

Ptyas mucosus

Python molurus

Rhamphotyphlops braminus

Sibynophis collaris

Xenochrophis piscator

serpentes (Venomous snakes)

Bugarus caeruleus

Bugarus fasciatus

Callophis macclellandii

ophiophagus hannah

Naja naja

Trimeresurus albolabris 


$\frac{\text { CHECKLIST OF FISHES OF ROYAL CHITWAN NATIONAL PARK }}{\text { (Edds, 1986) }}$

ORDER ANGUILLIFORMES

Family Anguillidae

Anguilla bengalensis (Gray and Hardwicke)

ORDER OSTEOGLOSSIFORMES

Family Notopteridae

Notopterus notopterus (Pallas)

ORDER CYPRINIFORMES

Family Cyprinidae

Accrossocheilus hexagonolepis (Mcclelland)

Amblypharyngodon mola (Hamilton)

Aspidoparia morar (Hamilton)

Aspidoparia jaya (Hamilton)

Barilius barila (Hamilton)

Barilius barna (Hamilton)

Barilius bendelisis (Hamilton)

Barilius bola (Hamilton)

Barilius shacra (Hamilton)

Barilius tileo (Hamilton)

Barilius vagra (Hamilton)

Chagunius chagunio (Hamilton)

Chela cachius (Hamilton)

Chela laubuca (Hamilton)

cirrhinus reba (Hamilton)

crossocheilus latius (Hamilton)

Danio aequipinnatus (McClelland)

Danio dangila (Hamilton)

Danio rerio (Hamilton)

Esomus danricus (Hamilton)

Garra gotyla (Gray)

Labeo angra (Hamilton)

Labeo bata (Hamilton)

Labeo boga (Hamilton)

Labeo calbasu (Hamilton) 


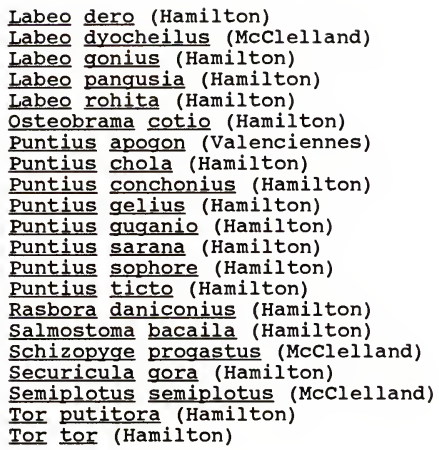

Family Psilorhynchidae

Psilorhynchus balitora (Hamilton)

Psilorhynchus sucatio (Hamilton)

Family Homalopteridae

Balitora brucei Gray

Family Cobitidae

Acanthophthalmus pangia (Hamilton)

Botea almorhae Gray

Botia dario (Hamilton)

Botia Iohachata Chaudhuri

Lepidocephalus guntea (Hamilton)

Noemacheilus beavani Gunther

Noemacheilus botia (Hamilton)

Noemacheilus corica (Hamilton)

Noemacheilus devdevi Hora

Noemacheilus rupecola (McClelland)

Noemacheilus savona (Hamilton)

ORDER SILURIFORMES

Family Bagridae

Aorichthys aor (Hamilton)

Aorichthys seenghala (Sykes)

Mystus bleekeri (Day) 
Mystus cavasius (Hamilton)

Mystus tengara (Hamilton)

Mystus vittatus (Bloch)

Rita rita (Hamilton)

Family siluridae

Ompok bimaculatus (Bloch)

ompok pabda (Hamilton)

Wallago attu (Schneider)

Family Schilbeidae

Ailia coila (Hamilton)

Clupisoma garua (Hamilton)

Eutropiichthys vacha (Hamilton)

Pseudeutropius atherinoides (Bloch)

Family Amblycipitidae

Ambleceps mangois (Hamilton)

Family Sisoridae

Bagarius yarrelli (Sykes)

Erethistes pussilus Muller and Troschel

Erethistoides montana (Hora)

Gagata cenia (Hamilton)

Gagata sexualis Tilak

Glyptothorax cavia (Hamilton)

Glyptothorax horai shaw and shebbeare

Glyptothorax pectinopterus (Mcclelland)

Glyptothorax telchitta (Hamilton)

Glyptothorax trilineatus Blyth

hara hara (Hamilton)

Laguvia riberoi Hora

Nagra viridescens (Hamilton)

Nagra nagra (Hamilton)

Pseudecheneis sulcatus (Mcclelland)

Family claridae

clarias batrachus (Linnaeus)

Family Heteropneustidae

Heteropneustes fossilis (Bloch) 
ORDER ATHERINIFORMES

Family Belonidae

Xenentodon cancila (Hamilton)

ORDER CHANNIFORMES

Family Channidae

Channa marulius (Hamilton)

Channa orientalis (Schneider)

Channa punctatus (Bloch)

Channa striatus (Bloch)

ORDER SYNBRANCHIFORMES

Family Synbranchidae

Monopterus cuchia (Hamilton)

ORDER PERCIFORMES

Family Chandidae

Chanda baculis (Hamilton)

Chanda nama (Hamilton)

Chanda ranga (Hamilton)

Family Nandidae

Badis badis (Hamilton)

Nandus nandus (Hamilton)

Family Mugilidae

Sicamugil cascasia (Hamilton)

Family Gobiidae

Family Belontidae

Glossogobius giuris (Hamilton)

Colisa fasciata (Schneider)

ORDER MASTACEMBELIFORMES

Family Mastacembelidae

Macrognathus aral (Bloch and Schneider)

Matacembelus armatus (Lacepede)

Matacembulus pancalus (Hamilton) 
ORDER TETRAODONTIDAE

Family Tetraodontidae

Tetrodon cutcutia (Hamilton) 


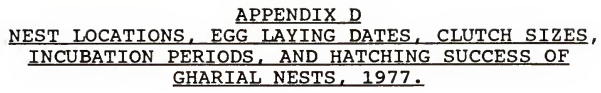

Table D-1. Nest locations, egg laying dates, clutch sizes, incubation periods and hatching success of gharial nests, 1977.

\begin{tabular}{|c|c|c|c|c|c|c|}
\hline $\begin{array}{l}\text { Nest } \\
\text { No. }\end{array}$ & Location & $\begin{array}{l}\text { Egg } \\
\text { Laying } \\
\text { Date }\end{array}$ & $\begin{array}{l}\text { Clutch } \\
\text { Size }\end{array}$ & $\begin{array}{l}\text { No. } \\
\text { Hatched }\end{array}$ & $\begin{array}{l}\text { Incu. } \\
\text { Period } \\
\text { In days }\end{array}$ & $\begin{array}{l}\text { Hatching } \\
\text { Success } \\
\text { in } \%\end{array}$ \\
\hline $\begin{array}{l}7701 \\
7702 \\
7703 \\
7704 \\
7705 \\
7706 \\
7707 \\
7708 \\
7709 \\
7710 \\
7711 \\
7712 \\
7713 \\
7714 \\
7715 \\
7716\end{array}$ & $\begin{array}{l}\text { Bhimband } \\
\text { Kathauna } \\
\text { Rapti Confl } \\
\text { Rapti Confl } \\
\text { Baghmara } \\
\text { Kathauna } \\
\text { Bhelaungi } \\
\text { Kathauna } \\
\text { Kathauna } \\
\text { Kathauna } \\
\text { Kali River } \\
\text { Kali River } \\
\text { Kali River } \\
\text { Pitaungi } \\
\text { Sikrauli } \\
\text { Rapti Confl }\end{array}$ & $\begin{array}{l}040277 \\
040277 \\
033177 \\
040577 \\
040277 \\
040177 \\
040377 \\
033177 \\
033177 \\
040377 \\
041877 \\
041377 \\
041477 \\
040877 \\
040977 \\
041377\end{array}$ & $\begin{array}{l}39 \\
16 \\
47 \\
38 \\
33 \\
32 \\
61 \\
31 \\
50 \\
34 \\
37 \\
35 \\
37 \\
32 \\
37 \\
33\end{array}$ & $\begin{array}{r}22 \\
8 \\
25 \\
27 \\
25 \\
28 \\
50 \\
22 \\
17 \\
28 \\
33 \\
34 \\
25 \\
29 \\
33 \\
32\end{array}$ & $\begin{array}{r}96 \\
96 \\
98 \\
96 \\
97 \\
94 \\
96 \\
98 \\
102 \\
95 \\
94 \\
83 \\
84 \\
91 \\
91 \\
87\end{array}$ & $\begin{array}{l}56.4 \\
50.0 \\
53.2 \\
71.0 \\
75.8 \\
87.5 \\
82.0 \\
71.0 \\
34.0 \\
82.3 \\
89.2 \\
97.1 \\
67.6 \\
90.6 \\
89.2 \\
97.0\end{array}$ \\
\hline & $\begin{array}{l}\text { Mean } \\
\text { Std. Dev. } \\
\text { Max. Value } \\
\text { Min. Value }\end{array}$ & & $\begin{array}{l}37 \\
9.4 \\
61 \\
16\end{array}$ & & $\begin{array}{c}93.6 \\
5.0 \\
102 \\
83\end{array}$ & $\begin{array}{l}74.6 \\
17.8 \\
97.1 \\
34.0\end{array}$ \\
\hline
\end{tabular}


Table D-2. Nest locations, egg laying dates, clutch sizes, incubation periods and hatching success of gharial nests, 1978 .

\begin{tabular}{|c|c|c|c|c|c|c|}
\hline $\begin{array}{l}\text { Nest } \\
\text { No. }\end{array}$ & Location & $\begin{array}{l}\text { Egg } \\
\text { Laying } \\
\text { Date }\end{array}$ & $\begin{array}{l}\text { Clutch } \\
\text { Size }\end{array}$ & $\begin{array}{l}\text { No. } \\
\text { Hatched }\end{array}$ & $\begin{array}{l}\text { Incu. } \\
\text { Period } \\
\text { In days }\end{array}$ & $\begin{array}{l}\text { Hatching } \\
\text { Success } \\
\text { in } \%\end{array}$ \\
\hline $\begin{array}{l}7801 \\
7802 \\
7803 \\
7804 \\
7805 \\
7806 \\
7807 \\
7808 \\
7809 \\
7810\end{array}$ & $\begin{array}{l}\text { Tamaspur } \\
\text { Tamaspur } \\
\text { Tamaspur } \\
\text { Tamaspur } \\
\text { Tamaspur } \\
\text { Banderjhola } \\
\text { Banderjhola } \\
\text { Banderjhola } \\
\text { Banderjhola } \\
\text { Kali River }\end{array}$ & $\begin{array}{l}040378 \\
040578 \\
040678 \\
040678 \\
040778 \\
040478 \\
040378 \\
040378 \\
040378 \\
040278\end{array}$ & $\begin{array}{l}45 \\
25 \\
18 \\
29 \\
24 \\
42 \\
44 \\
23 \\
27 \\
33\end{array}$ & $\begin{array}{r}40 \\
17 \\
2 \\
25 \\
5 \\
40 \\
18 \\
13 \\
0 \\
2\end{array}$ & $\begin{array}{r}83 \\
82 \\
88 \\
80 \\
82 \\
83 \\
86 \\
72 \\
99 \\
104\end{array}$ & $\begin{array}{r}88.9 \\
68.0 \\
11.1 \\
86.2 \\
20.8 \\
95.2 \\
40.9 \\
56.5 \\
0.0 \\
6.1\end{array}$ \\
\hline & $\begin{array}{l}\text { MEAN } \\
\text { Std. Dev. } \\
\text { Max. Valu } \\
\text { Min. Value }\end{array}$ & & $\begin{array}{l}31 \\
9.1 \\
45 \\
18\end{array}$ & & $\begin{array}{r}85.9 \\
8.8 \\
104 \\
72\end{array}$ & $\begin{array}{r}47.4 \\
34.7 \\
95.2 \\
0.0\end{array}$ \\
\hline
\end{tabular}


Table D-3. Nest locations, egg laying dates, clutch sizes, incubation periods and hatching success of gharial nests, 1979.

\begin{tabular}{|c|c|c|c|c|c|c|}
\hline $\begin{array}{l}\text { Nest } \\
\text { No. }\end{array}$ & Location & $\begin{array}{l}\text { Egg } \\
\text { Laying } \\
\text { Date }\end{array}$ & $\begin{array}{l}\text { Clutch } \\
\text { size }\end{array}$ & $\begin{array}{l}\text { No. } \\
\text { Hatched }\end{array}$ & $\begin{array}{l}\text { Incu. } \\
\text { Period } \\
\text { In days }\end{array}$ & $\begin{array}{l}\text { Hatching } \\
\text { Success } \\
\text { in } \%\end{array}$ \\
\hline $\begin{array}{l}7901 \\
7902 \\
7903 \\
7904 \\
7905 \\
7906 \\
7907 \\
7908 \\
7909 \\
7910 \\
7911 \\
7912 \\
7913 \\
7914 \\
7915 \\
7916\end{array}$ & $\begin{array}{l}\text { Kali River } \\
\text { Kali River } \\
\text { Kali River } \\
\text { Murdarbhan } \\
\text { Jogimara } \\
\text { Khoria } \\
\text { Kathauna } \\
\text { Kathauna } \\
\text { Bhelaungi } \\
\text { Bhelaungi } \\
\text { Bhelaungi } \\
\text { Bhelaungi } \\
\text { Bhelaungi } \\
\text { Bhelaungi } \\
\text { Khoria } \\
\text { Khoria }\end{array}$ & $\begin{array}{l}040979 \\
040579 \\
032879 \\
040279 \\
040379 \\
041279 \\
040379 \\
032979 \\
032879 \\
032979 \\
033079 \\
040179 \\
040179 \\
040279 \\
041279 \\
041279\end{array}$ & $\begin{array}{l}38 \\
27 \\
46 \\
23 \\
44 \\
45 \\
14 \\
38 \\
16 \\
38 \\
21 \\
52 \\
46 \\
38 \\
34 \\
23\end{array}$ & $\begin{array}{r}4 \\
11 \\
16 \\
1 \\
11 \\
15 \\
13 \\
6 \\
8 \\
37 \\
21 \\
40 \\
39 \\
32 \\
32 \\
8\end{array}$ & $\begin{array}{l}66 \\
70 \\
74 \\
73 \\
69 \\
63 \\
65 \\
70 \\
74 \\
73 \\
73 \\
67 \\
67 \\
66 \\
60 \\
63\end{array}$ & $\begin{array}{r}10.5 \\
40.7 \\
34.8 \\
4.3 \\
25.0 \\
33.3 \\
92.9 \\
15.8 \\
50.0 \\
97.4 \\
100.0 \\
76.9 \\
84.8 \\
84.2 \\
94.1 \\
34.8\end{array}$ \\
\hline & $\begin{array}{l}\text { Mean } \\
\text { Std. Dev. } \\
\text { Max. Value } \\
\text { Min. Value }\end{array}$ & & $\begin{array}{l}33.9 \\
11.4 \\
52 \\
14\end{array}$ & & $\begin{array}{l}68.3 \\
4.2 \\
74 \\
60\end{array}$ & $\begin{array}{c}55.0 \\
33.1 \\
100 \\
4.3\end{array}$ \\
\hline
\end{tabular}


Table D-4. Nest locations, egg laying dates, clutch sizes, incubation periods and hatching success of gharial nests, 1980 .

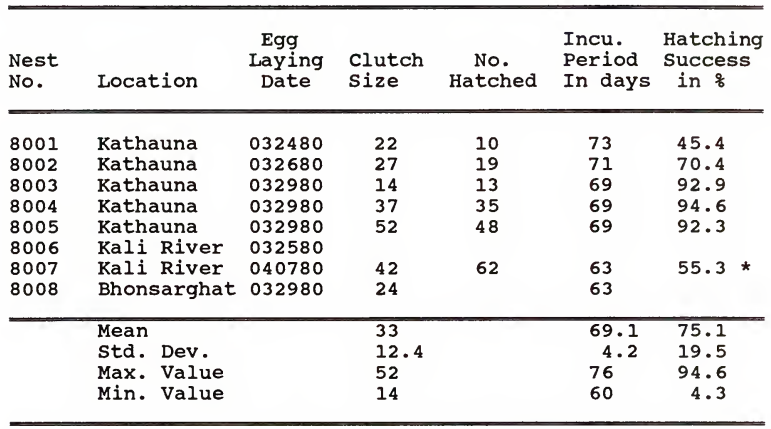

* Hatch rate was calculated combining three nests (Nest \# 8006,8007 and 8008) together. 
Table D-5. Nest locations, egg laying dates, clutch sizes, incubation periods and hatching success of gharial nests, 1981.

\begin{tabular}{|c|c|c|c|c|c|c|}
\hline $\begin{array}{l}\text { Nest } \\
\text { No. }\end{array}$ & Location & $\begin{array}{l}\text { Egg } \\
\text { Laying } \\
\text { Date }\end{array}$ & $\begin{array}{l}\text { clutch } \\
\text { size }\end{array}$ & $\begin{array}{l}\text { No. } \\
\text { Hatched }\end{array}$ & $\begin{array}{l}\text { Incu. } \\
\text { Period } \\
\text { In days }\end{array}$ & $\begin{array}{l}\text { Hatching } \\
\text { Success } \\
\text { in } \&\end{array}$ \\
\hline $\begin{array}{l}8101 \\
8102 \\
8103 \\
8104 \\
8105 \\
8106 \\
8107 \\
8108 \\
8109 \\
8110 \\
8111 \\
8112 \\
8113\end{array}$ & $\begin{array}{l}\text { Kali River } \\
\text { Kali River } \\
\text { Kali River } \\
\text { Kali River } \\
\text { Kali River } \\
\text { Kali River } \\
\text { Kali River } \\
\text { Bhosarghat } \\
\text { Bijuli Conf } \\
\text { Jogimara } \\
\text { Rapti Confl } \\
\text { Kathauna } \\
\text { Velaungi }\end{array}$ & $\begin{array}{l}032981 \\
040481 \\
041081 \\
041081 \\
040981 \\
040581 \\
041081 \\
032681 \\
040581 \\
040781 \\
040481 \\
040381 \\
040381\end{array}$ & $\begin{array}{l}31 \\
41 \\
41 \\
35 \\
34 \\
36 \\
33 \\
36 \\
32 \\
30 \\
35 \\
32 \\
35\end{array}$ & $\begin{array}{r}30 \\
21 \\
35 \\
32 \\
31 \\
8 \\
1 \\
30 \\
14 \\
23 \\
11 \\
0 \\
0\end{array}$ & $\begin{array}{l}75 \\
79 \\
74 \\
75 \\
79 \\
83 \\
78 \\
89 \\
75 \\
73 \\
80 \\
85 \\
85\end{array}$ & $\begin{array}{c}96.77 \\
51.22 \\
85.37 \\
91.43 \\
91.18 \\
22.22 \\
3.03 \\
83.33 \\
43.75 \\
76.67 \\
31.43 \\
0.0 \\
0.0\end{array}$ \\
\hline & $\begin{array}{l}\text { Mean } \\
\text { Std. Dev. } \\
\text { Max. Value } \\
\text { Min. Value }\end{array}$ & & $\begin{array}{l}34.7 \\
3.2 \\
41 \\
30\end{array}$ & & $\begin{array}{l}79.2 \\
4.8 \\
89 \\
73\end{array}$ & $\begin{array}{r}52.0 \\
36.1 \\
96.8 \\
0.0\end{array}$ \\
\hline
\end{tabular}


Table D-6. Nest locations, egg laying dates, clutch sizes, incubation periods and hatching success of gharial nests, 1987.

\begin{tabular}{|c|c|c|c|c|c|c|}
\hline $\begin{array}{l}\text { Nest } \\
\text { No. }\end{array}$ & Location & $\begin{array}{l}\text { Egg } \\
\text { Laying } \\
\text { Date }\end{array}$ & $\begin{array}{l}\text { Clutch } \\
\text { Size }\end{array}$ & $\begin{array}{l}\text { No. } \\
\text { Hatched }\end{array}$ & $\begin{array}{l}\text { Incu. } \\
\text { Period } \\
\text { In days }\end{array}$ & $\begin{array}{l}\text { Hatching } \\
\text { Success } \\
\text { in \% }\end{array}$ \\
\hline $\begin{array}{l}8701 \\
8702 \\
8703 \\
8704 \\
8705 \\
8706 \\
8707 \\
8708 \\
8709 \\
8710\end{array}$ & $\begin{array}{l}\text { Velaungi } \\
\text { Velaungi } \\
\text { Velaungi } \\
\text { Velaungi } \\
\text { Velaungi } \\
\text { Mardi Confl } \\
\text { Kali River } \\
\text { Kali River } \\
\text { Kali River } \\
\text { Kali River }\end{array}$ & $\begin{array}{l}032587 \\
040387 \\
040787 \\
040787 \\
040887 \\
040287 \\
041087 \\
040887 \\
040387 \\
040387\end{array}$ & $\begin{array}{l}44 \\
37 \\
43 \\
44 \\
51 \\
39 \\
40 \\
38 \\
39 \\
31\end{array}$ & $\begin{array}{r}0 \\
36 \\
42 \\
0 \\
46 \\
10 \\
15 \\
36 \\
36 \\
26\end{array}$ & $\begin{array}{l}79 \\
77 \\
74 \\
79 \\
73 \\
79 \\
75 \\
72 \\
78 \\
78\end{array}$ & $\begin{array}{r}0.0 \\
97.3 \\
97.7 \\
0.0 \\
90.2 \\
25.6 \\
37.5 \\
94.7 \\
92.3 \\
83.9\end{array}$ \\
\hline & $\begin{array}{l}\text { Mean } \\
\text { Std. Dev. } \\
\text { Max. Value } \\
\text { Min. Value }\end{array}$ & & $\begin{array}{l}40.6 \\
5.0 \\
51 \\
31\end{array}$ & & $\begin{array}{l}76.4 \\
2.5 \\
79 \\
72\end{array}$ & $\begin{array}{r}61.9 \\
39.2 \\
97.7 \\
0.0\end{array}$ \\
\hline
\end{tabular}


APPENDIX E

POST-RELEASE MOVEMENT PATTERN

OF GHARIALS, 1987 


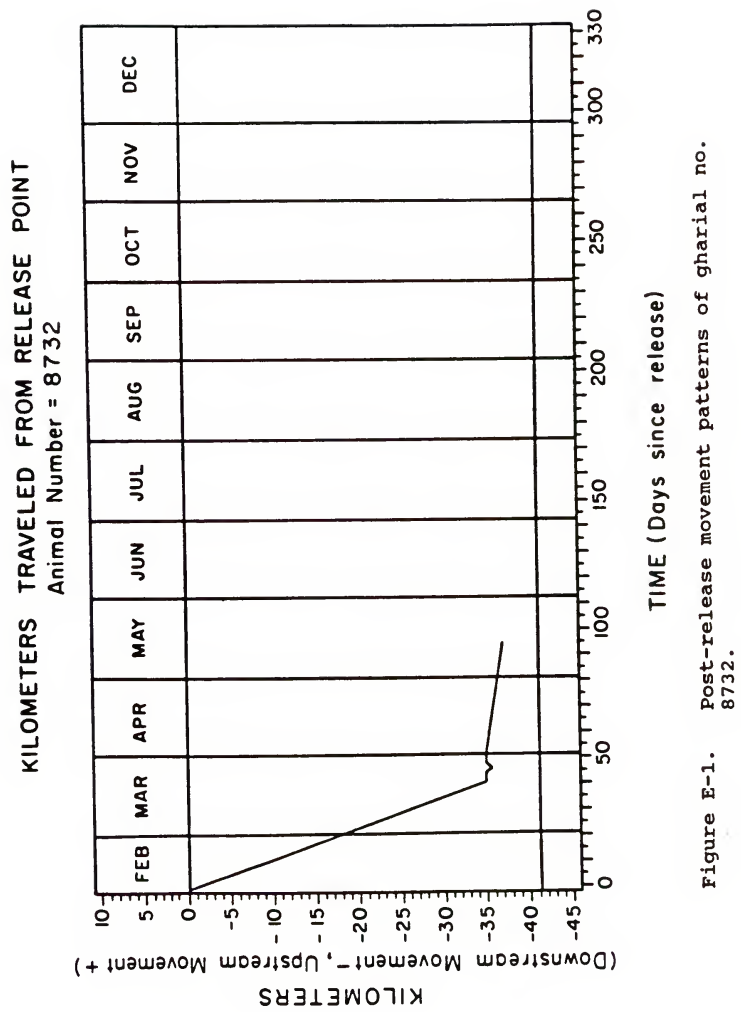




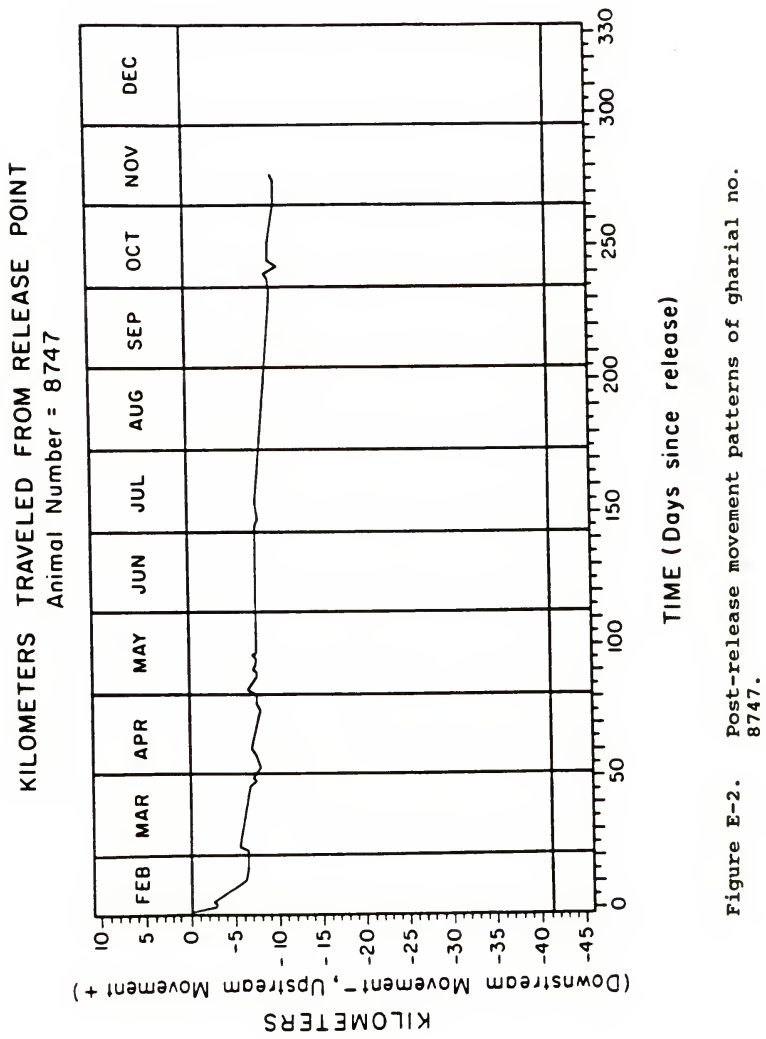




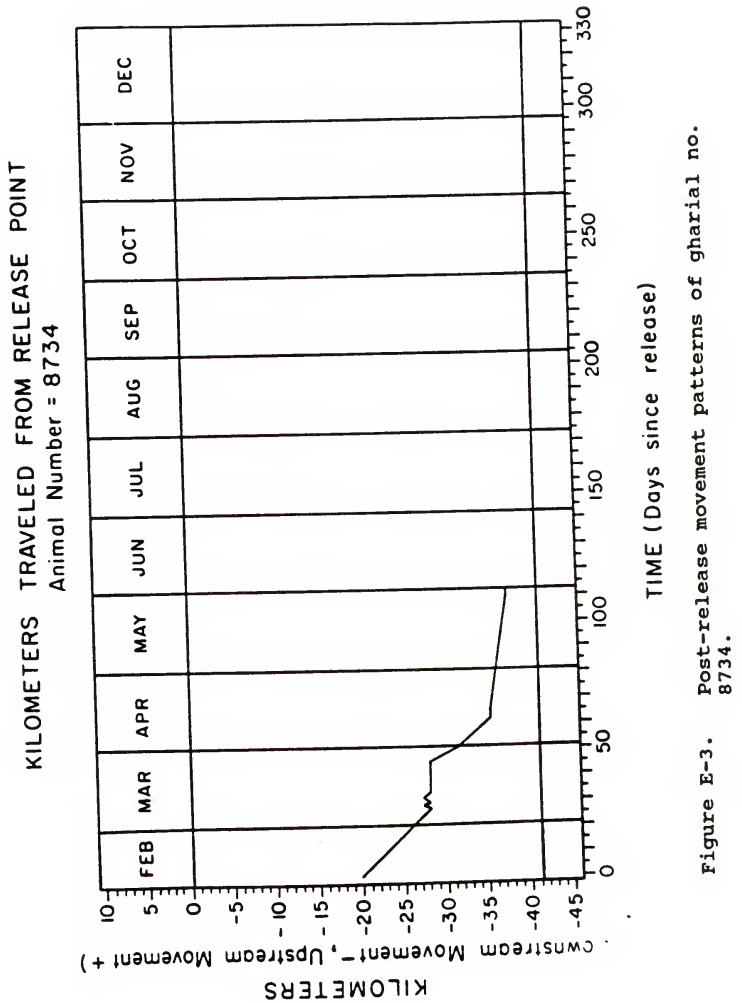




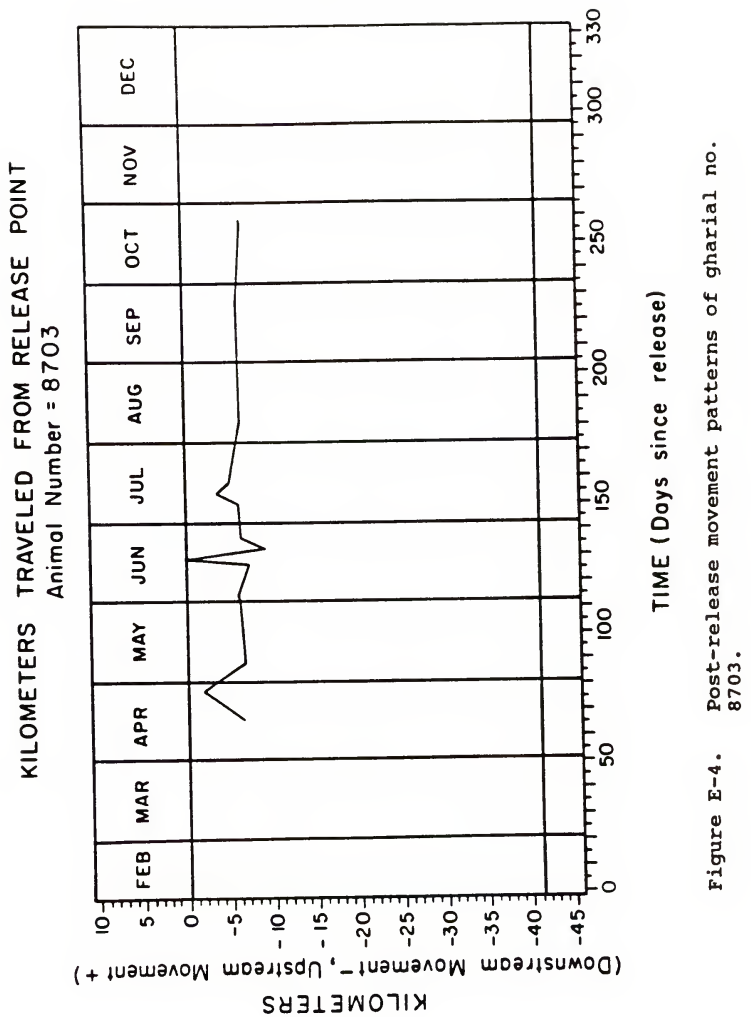




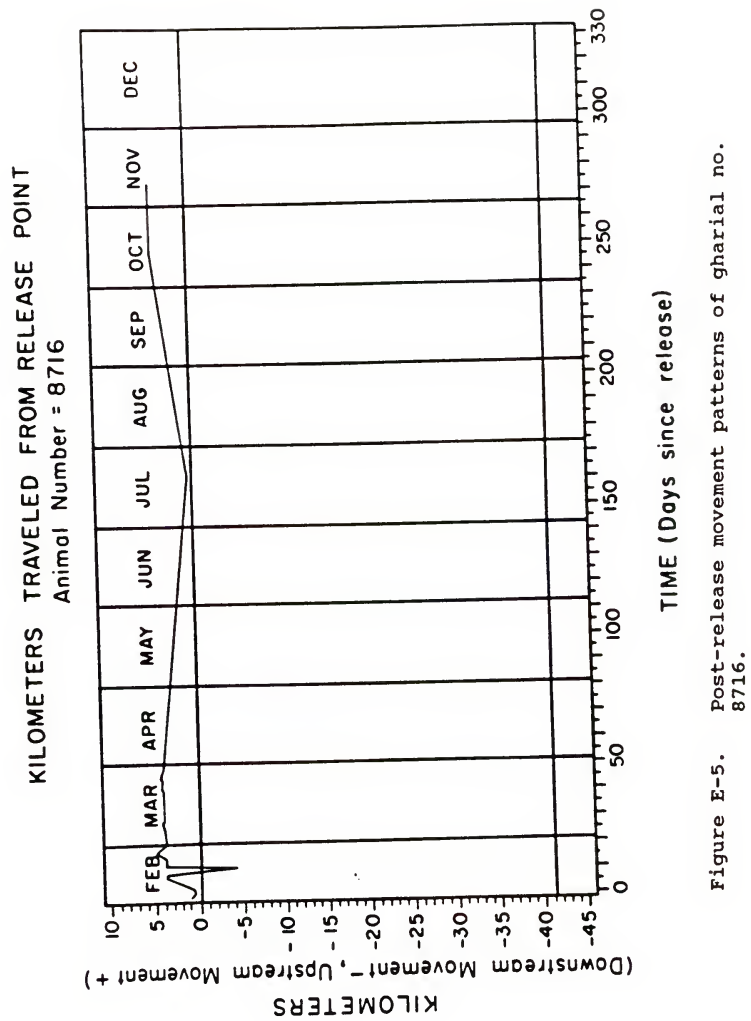




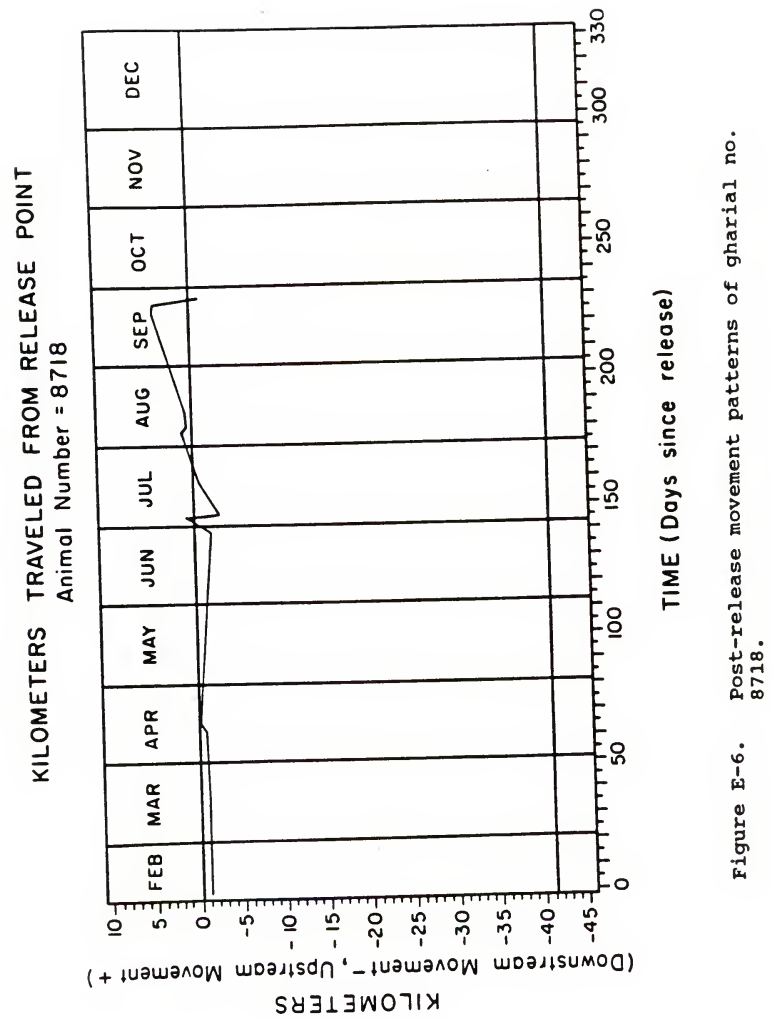




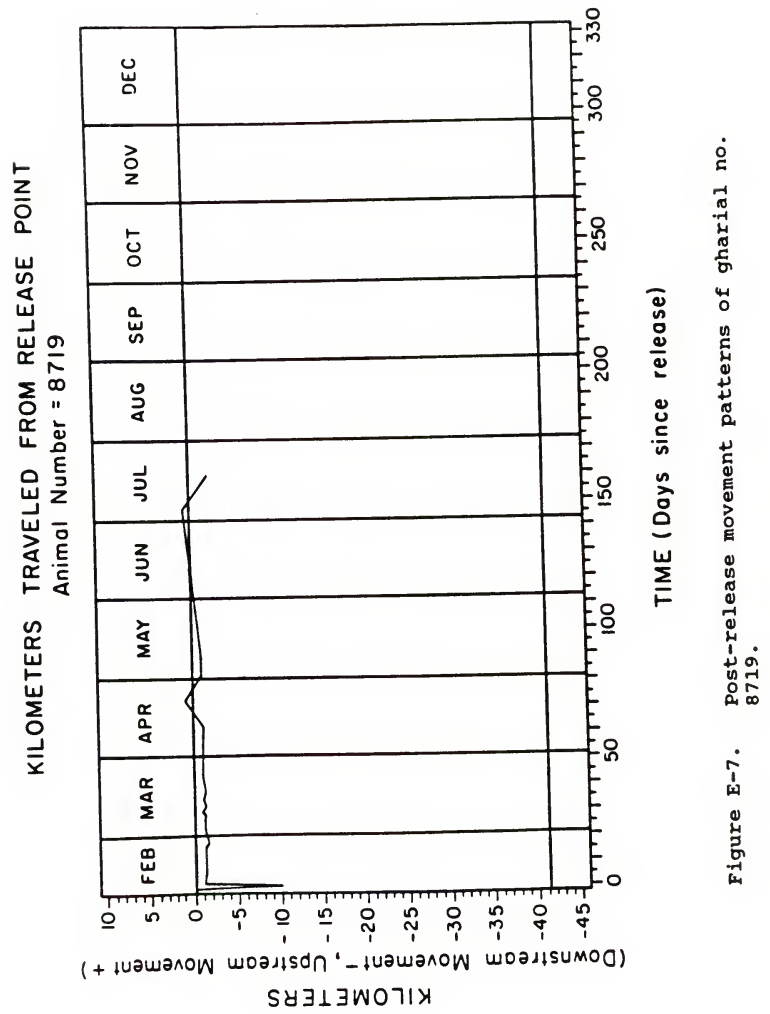




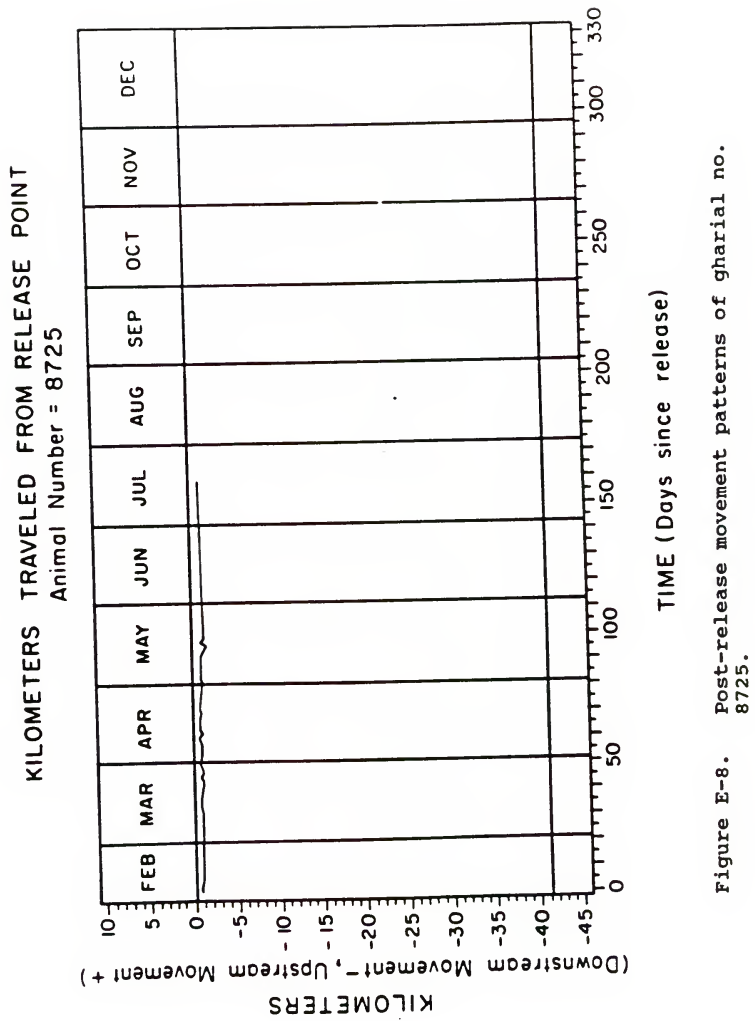




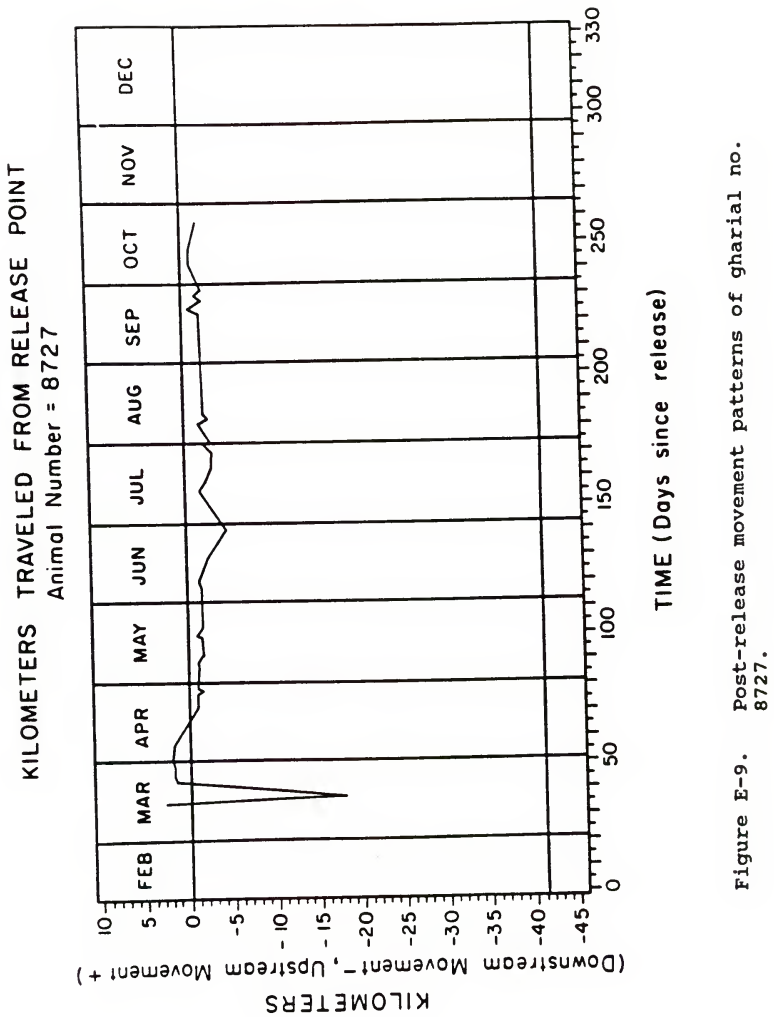




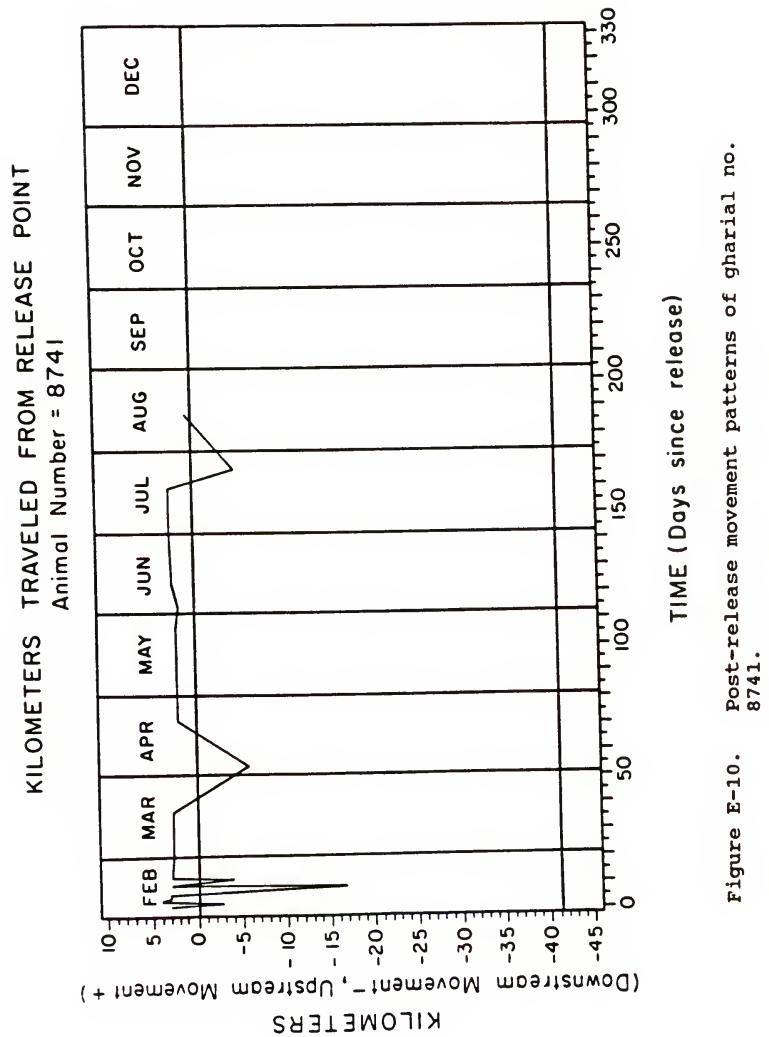




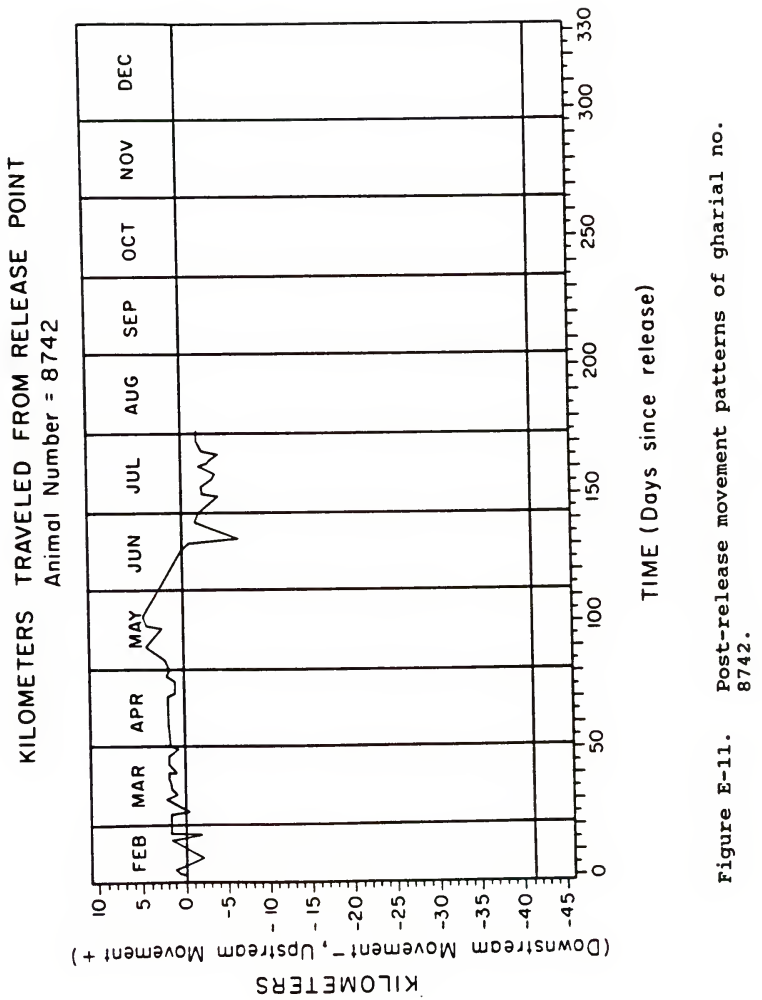




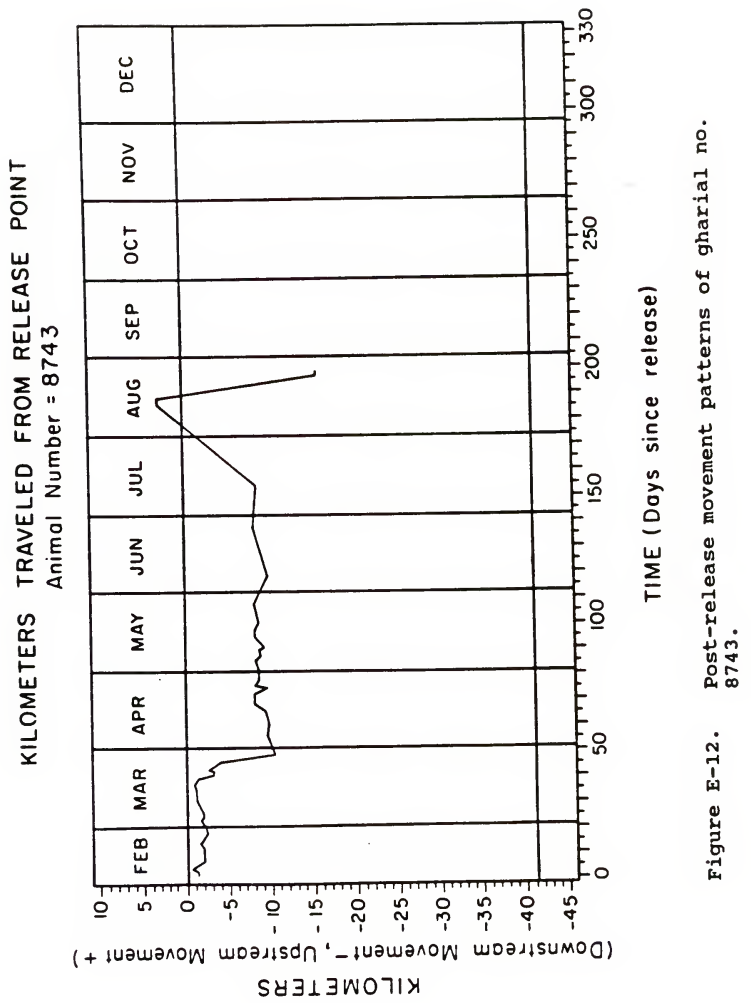




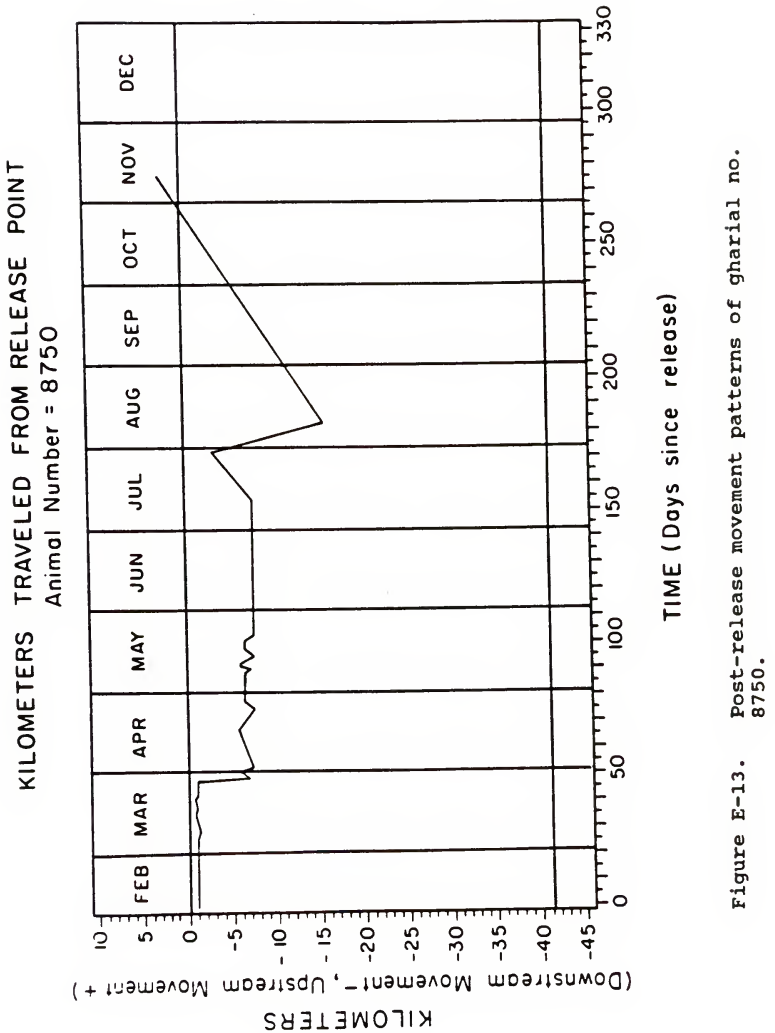




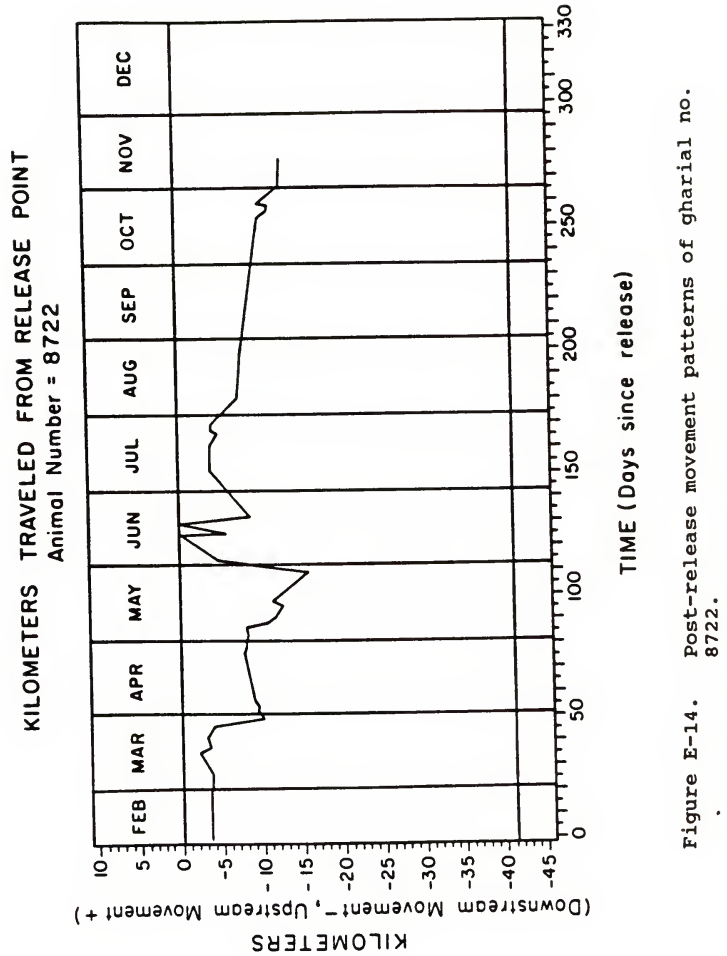




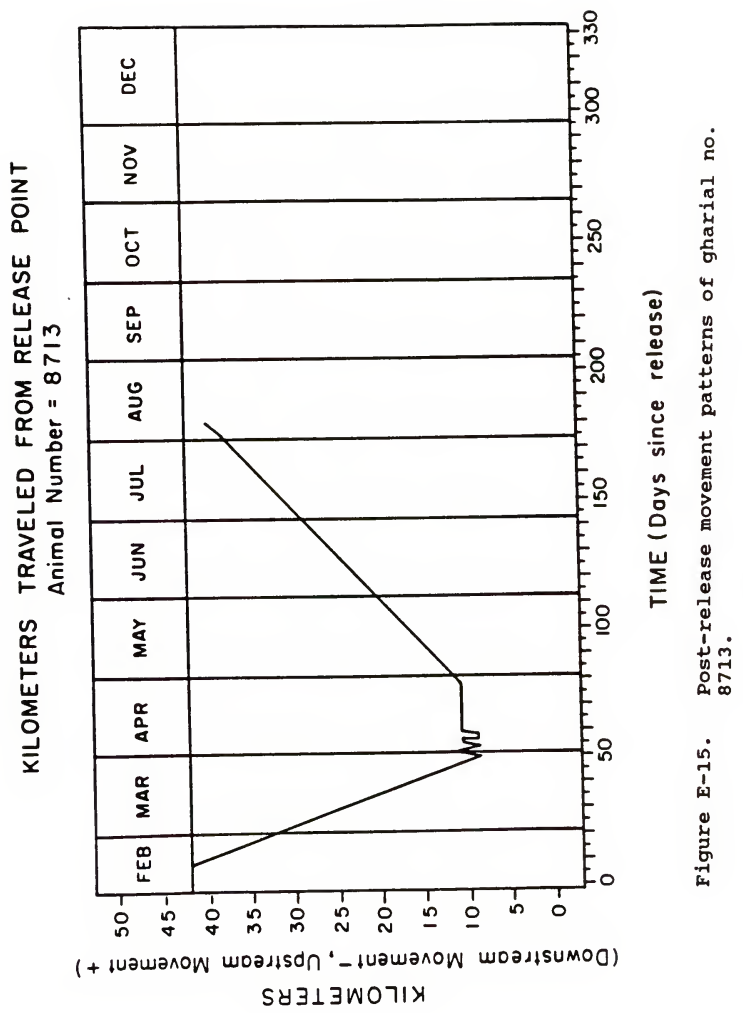




\section{LITERATURE CITED}

Acharjyo, R. N., S. Biswas, and R. Mishra. 1974. Some notes on gharial (Gavialis gangeticus) in captivity. $J$. Bombay Nat. Hist. Soc. 72: 558-560.

Adams, A. L. 1867. Wandering of a naturalist in India. Edmonton and Dougler, Edinburg.

Allen, D. L. 1974. Our wildlife legacy. Funk and Wagnalls Co., New York, N.Y. 422 pp.

Andrews, R. M. 1976. Growth rate in island and mainland anoline lizard. Copeia 1976 3: 477-482.

Annadale, N. 1915. Fauna of the Chilka Lake: reptiles and batrachia. Mem. Indian Mus. 5: 167-174.

Barton, C. G. 1927. Gharial in Burma. J. Bombay Nat. Hist. Soc. 33: 450 .

Basu, D. 1980. Baby crocs in a valley of death. Inter. wildl. 10: 3-11.

Bauffetaut, E. 1979. The evolution of the crocodilians. Science 1979 (December): 124-132.

Behura, B. K., and L. A. K. Singh. 1978. Conservation of crocodiles in India. Indian For. (Spec. Issue on Inter. Symp. on Tiger): 83-92.

Biswas, S. 1970a. A primary survey of gharial in Kosi River. Indian For. 96: 704 .

1970b. Proposal for protection of Marsh crocodile. Indian For. 96: 707.

Bolton, M. 1975. Royal Chitwan National Park management plan, 1975-1979. HMG/FAO/UNDP Nat. Parks Wildl. Conserv. Proj. Work. Doc. 2, Kathmandu Nepal. 105 pp.

Brazaitis, P. 1973. The identification of the living crocodilians. Zoologica $58(1-4)$ : 59-101.

Bustard, H. R. 1972. Sea turtles: conservation and natural history. Collins, London and Sydney. 
1974. Status of gharial in 1974. Page $4 \underline{\text { in }} \mathrm{L}$. A. K. Singh, B. C. Choudhury (ed.) Indian crocodile conservation and research: proceedings of the Ist Indian crocodile research symposium, 1979.

17: $3-8$ 1975. A future for the gharial. Cheetal

Herpetol. 5: 747-748.

1980. Maternal care in the gharial (Gavialis gangeticus). Brit J. Herpetol. 6: 63-64.

1980a. Extinction of the gharial in Bhutan. Brit. J. Herpetol. 6: 68 .

1980b. Status of the gharial (Gavialis

gangeticus) in Bhutan. J. Bombay Nat. Hist. Soc. 77: 150 .

1982. Preliminary account of the gharial rehabilitation in Rajasthan. Page 21 in L. A. K. Singh, B. C. Choudhury (eds.) Indian crocodile conservation and research: proceedings of the lst Indian crocodile research symposium, 1979.

1984. Breeding the gharial (Gavialis gangeticus): captive breeding, a key conservation strategy. Symp. Zool. Soc. Lond. 52: 385-406.

and L. A. K. Singh. 1982. Movement of the wild Gavialis gangeticus (Gmelin)) in the river Mahanadi, Orissa, India. Brit. J. Herpetol. 6: 287-291.

L. A. K. Singh, and L. N. Acharjyo. 1982 . Rehabilitation of the gharial in orissa. Page 20 in $\mathrm{L}$. A. K. Singh, B. C. Choudhury (eds.) Indian crocodile conservation and research: proceedings of the Ist Indian crocodile research symposium, 1979.

Caughley, G. 1969. Wildlife and recreation in the Trisuli watershed and other areas in Nepal. HMG/FAO/UNDP Trisuli Watershed Develop. Proj., Proj. Rep. 6 (Kathmandu, Nepal). 54 pp.

Chabreck, R. H. 1971. Management of the American alligator. Pages 137-144 in Crocodiles: 1st work. meeting of crocodiles spec. I. Intl. Union Conserv. Nat. Natural Resours. Suppl. Paper 32: 1-191. 
and T. Joanen. 1979. Growth rate of American alligators in Louisiana. Herpetologica 35: 51-57.

Chowdhury, S., H. R. Bustard, and B. K. Tandan. 1983. Incubation and hatching of eggs of Gavialis gangeticus in hatcheries. Brit. J. Herpetol. 6: 337-342.

Choudhury, B. C., and H. R. Bustard. 1981. Restocking mugger crocodile (Lesson) in Andhra Pradesh: evaluation of a pilot release. J. Bombay Nat. Hist. Soc. 79: 275-289.

cott, H. B. 1961. Scientific result of an enquiry into the ecology and economic status of the Nile crocodile, crocodylus niloticus in Uganda and Northern Rhodesia. Trans. Zool. Soc. London 29: 21-356.

, and A. C. Pooley. 1972. Crocodiles: The status of crocodilians in Africa. II. Intl. Union Conserv. Nat. and Natural Resours. Suppl. Pap. 33: 1-98.

Daniel, J. C. and S. A. Hussain. 1974. The record (?) salt water crocodile (Crocodylus porosus). J. Bombay Nat. Hist. Soc. 71: 309-312.

Deitz, D. C., and T. C. Hines. 1980. Alligator nesting in north-central Florida. Copeia 1980: 249-258.

Densmore, L. D. 1983. Biochemical and immunological systematics of the order crocodilia. Pages 397-465 in Evolutionary biology, M. Hecht, B. Wallace and G. Prance (eds.), Plenum Press. New York and London 1983: 1-499.

Dhungel, S. 1984. Ecology of the hog deer in Royal Chitwan National Park, Nepal. Ph.D. dissertation, Dept. of Nat. Parks and Wildl. Cons., Kathmandu, Nepal 114 pp.

Dowling, H. G., and P. Brazaitis. 1966. Size and growth in captive crocodiles. Inter. Zoo Year Book 6: 265-270.

Edds, D. 1986. The fishes of Royal Chitwan National Park. Dep. Zool., Oklahoma State Univ., stillwater. 14 pp.

Evans, M., C. Heardman, S. Houghton, and C. Tiller. 1985. An ecological survey of the Narayani River, within the Royal Chitwan National Park - A study of the fish distribution and their predators in particular the smooth Indian otter. Edinburgh Univ. Expedition Nepal (Report submitted to King Mahendra Trust Kathmandu, Nepal). $28 \mathrm{pp}$. 
Faizuddin, M. 1985. Distribution, abundance and conservation of gharials in Bangladesh. Tiger Pap. 22-23.

F. A. O. 1974. India. A preliminary survey of the prospects for crocodile farming. United Nations Food and Agric. organ., Rome, Italy.

Ferguson, M. W. J. 1985. Reproductive biology and embryology of the crocodilians. Pages 329-491 in C. Gans, F. Billett and P. F. A. Maderson (eds.) Biology of the reptilia, 14-A. John Wiley and Sons, Inc, England.

Fukada, H. 1961. Biological studies on the snake. VIII. On the growth formulae of snakes and their application to other reptiles. Bull. Kyoto Univ. Educ. Ser. Nat. Sci. 17: $16-40$.

Gmelin, J. F. 1789. Linne susteme naturae. Leipzig ed. 13. 1978 (1): 1057 .

Graham, A. 1968. The lake Rudolf crocodile (Crocodylus niloticus) population. Wildl. Serv. Rep. (submitted to Kenya Game Dep.).

Groombridge, B. 1982. The IUCN amphibia-reptilia red data book I. Part 1. Testudines, Crocodilia and Rhynchocephalia. Inter. Union Conserv. Nat. Natural Resour., Gland Switzerland: 405-413.

Guggisburg, C. A. W. 1972. Crocodiles. Stackpole Books, Harrisburg, $\mathrm{Pa} .195 \mathrm{pp}$.

Gurung, K. K. 1983. Heart of the jungle. Andre Deutsch Ltd. London. 197 pp.

Hall, P. M. and D. R. Johnson. 1987. Nesting biology of Crocodylus novaequineae in Lake Murray District, Papua New Guinea. Herpetologica 43: 249-258.

Hecht, M. K., and B. Malone. 1972. On the early history of the Gavilid crocodilians. Herpetologica 28: 281-284.

Hines, T. C. and H. F. Percival. 1987. Alligator management and value-added conservation in Florida. Pages 164-173 in D. J. Decker and G. R. Goff (eds.) Valuing wildlife economic and social perspectives. The wildlife Society, New York Chapter, Westview Press Inc. 
Honneger, R. E. 1971. Zoo breeding and crocodile bank. Pages 86-97 in Crocodiles: Proc. Ist working meeting croc. sp. group. Intl. Union Conserv. Nat. and Natural Resours. Publ., New Ser. Suppl. Pap. 32: 1-191.

Hornanday, W. T. 1885. Two years in the jungle. Charles Scribner's Sons, New York, N. Y. 39-57.

IUCN Red Data Book. 1975. Inter. Union. Conserv. Nat. and Natural Resour. Morges, Switzerland.

Jacobson, E. 1982. Captive crocodile health problem. United Nations Food and Agric. Organ. Field Doc. 11. Dehradun, India. $21 \mathrm{pp}$.

Jennings, M. L., H. F. Percival and A. R. Woodward. 1987. Evaluation of alligator hatchling and egg removal from 3 Florida Lakes. Proc. Annu. Conf. Southeast Assoc. Fish and wildl. Agencies $10 \mathrm{pp}$ (in press).

Joanen, T. and L. McNease. 1971. Propagation of American alligator in captivity. Proc. Southeast. Assoc. Game and Fish Comm. 22: 106-116.

L. McNease, and G. Perry. 1977. Effects of simulated flooding on alligator eggs. Proc. Ann. Conf. Southeast. Assoc. Fish and Wildl. Agencies 31: 33-35.

and L. McNease. 1987. Alligator farming research in Louisiana U.S.A. Pages 329-340 in G. J. W. Webb, S. C. Manolis, and P. J. Whitehead (eds.) Wildife management: crocodiles and alligators. Surrey Beally and Sons Pvt. Ltd., Cleipping Norton, Australia.

Joshi, M. D. 1985. Environment of Nepal. Pages 392-402 in T. C. Majupuria, ed. Nepal nature's paradise. White Lotus Co., Ltd., Bangkok, Thailand.

Kar, C. S. 1985. A gharial at Gahirmatha Coast, Orissa, India. J. Bombay Nat. Hist. Soc. 82: 671-673.

Kalin, J. 1955. Crocodilia. J. Piveleau Traite de Paleontologie. Paris. Masson et Cie 5: 695-784.

Khan, M. A. R. 1982a. The gharial - a dwindling species of Bangladesh. J. Environ. 1: 9-15.

1982b. Wildlife of Bangladesh (checklist). Rep. Univ. Dhaka Report 33 pp. 
Kimura, W. 1976. Artificial incubation of crocodile eggs. Atagawa Trop. and Alligator Garden, Atagawa, Izu Shinzuoka, Japan. Res. Report 4: 44 pp.

1978. Artificial incubation of the gharial eggs. Bull. Atagawa Inst. Trop. and Alligator Garden, Atagawa, Izu Shinzuoka, Japan. 16 pp.

Krishnamurthi, V. S. and R. Bhaskaram. 1980. Some observations on the growth of captive crocodiles. $\mathrm{J}$. Bombay Nat. Hist. Soc. 77: 516-521.

Langston, W. Jr. 1965. Fossil crocodilians from Colombia and Cenozoic history of the crocodilia in South America. Univ. California Publ. Geol. Sci. 52: 1-157.

Laurie, A. 1978. The ecology and behavior of the greater one horned rhinoceros. Ph.D. dissertation, Univ. Cambridge. 450 pp.

Lowis, R. M. 1915. Gharial catching on the Indus. J. Bombay Nat. Hist. Soc. 23: 779 .

Lull, R. S. 1944. Fossil gavials from North India. Am. J. Sci. 242: 417-430.

Martin, B. G., and A. D'A Bellairs. 1977. The narial excrescence and pterygoid bulla of the gharial, Gavialis gangeticus (Crocodilia). J. Zool. Lond. 182: 541-558.

Maskey, T. M. 1979. RCNP monthly report. Dep. Nat. Parks Wildl. Conserv., Nepal. 3 pp (mimeo).

1984. Survey of the gharial in Kosi, Kali and Narayani Rivers in Nepal. Dep. Nat. Parks and Wildl. Conserv., Kathmandu. 12 pp (mimeo).

and H. R. Mishra. 1982. Conservation of gharial in Nepal. Pages 185-196 in T. C. Majupuria, (ed.) Wild is beautiful. S. Devi, Lalitpur Colony, Lashkar (Gwalior), M. P. India.

McGladdery, S., C. A. Mcclean, F. G. Maisels, W. J. L. Miller, and M. Allison. 1980. Aberdeen University Expedition to Nepal. Rep. submitted to Dep. Nat. Parks Wildl. Conserv., Nepal. 121 pp.

Mishra, H. and T. Maskey. 1981. Saving the gharial crocodile. Die Inter. Zeitschrift fur Tier, Mench und Nat $15-18$. 
Mitra, D. K. 1979. Survey of gharial. Wildl. Newsl. Dehradun, India. 63-66 pp.

Mitchell, J. C., and G. R. Zug. 1986. Guide to the amphibians and reptiles of the Royal Chitwan National Park, Nepal. Smithsonian Inst. 22 pp.

Neill, W. T. 1971. The last of the ruling reptiles: alligator, crocodiles and their kin. Columbia Univ. Press, Ithaca, New York, N.Y. 486 pp.

Neu, A., B. Byers, and J. M. Peek. 1974. Technique for analysis of utilization availability data. J. Wildl. Manag. 38: 541-545.

Nichols, J. D., R. H. Chabreck, and W. Conley. 1976. The use of restocking quotas in crocodilian harvest management. Trans. North Am. Wildl. and Nat. Res. Conf. 41: 385395.

Panday, R. K. 1987. Effect of altitude on the geography of Nepal. Cent. altitude geography. Kathmandu, Nepal. 408 pp.

Parshad, B. 1964. The gharial (Gavialis gangeticus). J. Bombay Nat. Hist. Soc. $72: 557$.

Pooley, A. C. 1962. The Nile crocodile, crocodilus niloticus: notes on the incubation period and growth rates of juveniles. Lammergeyer 2: 1-55.

1966. Crocodiles and crocodile farming. Afr. Wildl. 20: 211-216.

1969a. Preliminaries studies on the breeding of Nile crocodile Crocodylus niloticus in zululand. Lammergeyer 10: 23-24.

1969b. Some observations on the rearing of crocodiles. Lammergeyer 3: 45-57.

1971. Crocodile rearing and restocking. Publ. Inter. Union Cons. Nature and Nat. Res., New ser. 32 : 104-130.

1973. Notes on the ecology of the Lake st. Lucia crocodile population. Pages $81-90$ in crocodiles: Proc. 2nd Working Meet. of crocodile Spec. Intl. Union Conserv. Nat. Natural Resours. Suppl. Pap. 41: 1-115.

Rao, C. J. 1933. Gavial on the Indus. J. Sind Nat. Hist. Soc. 1: $37 \mathrm{pp}$. 
Rao, M. V. S. 1987. Incubating eggs of the gharial for conservation purpose. Pages 503-505 in G. J. W. Webb, S. C. Manolis and P. J. Whitehead (eds). Wildlife management: crocodiles and alligators. Surrey Beatty and Sons Pvt Ltd., cleipping Norton, Australia.

Sale, J. B. 1986. Reintroduction in wildlife management. Indian For. 10: 867-873.

Shanker, K. 1985. Water resources. Pages 25-31 in T. C. Majupuria, (ed.) Nepal nature's paradise. White Lotus co., Ltd., Bangkok, Thailand.

and P. B. Shrestha. 1985. Pages 39-44 in T. C. Majupuria (ed.) Nepal nature's paradise. White Lotus co. Ltd. Bangkok, Thailand.

Sharma, C. K. 1977. River system of Nepal. Nepal Nature Cons. Soc. Ann. 1977.

Sharma, M. S. 1977. Report on the survey of gavial in the Narayani River system. H.M.G. Department of National Parks and Wildlife, Nepal. $15 \mathrm{pp}$. (mimeo).

Sharma, R. 1985. Result of 1981 survey for gharial in northern National Chambal Sanctuary. J. Bombay Nat. Hist. Soc. 82: 215-218.

shortt, W. H. O. 1921. A few hints on crocodile shooting. J. Bombay Nat. Hist. Soc. 28: 291 pp.

sill, W. D. 1968. The zoo-geography of the crocodilia. Copeia 1968: 76-88.

1971. Nota preliminar sobre un neuvo garial del pliocene de Venezuala, una discussion de los gavialis sudamericanes. Ameghiniana 1970: 151-159.

singh, L. A. K. 1977. When back to the wild. Cheetal 1 and $2: 20-22$.

1977. Conservation of nature and future of mankind (man and crocodile). Tiger paper. 4: 16-17.

1978. Gharial conservation in orissa, Indian For. 104: 823-829.

1981. Observation on the movement of two captive-reared mugger crocodiles, when returned to the wild. J. Bombay Nat. Hist. Soc. 80: 86-90. 
1986. Crocodiles: status and management.

Pages 261-275 in T. C. Majupuria, (ed.) Wildilfe wealth of India. Tecpress Service, L.P. Bangkok, Thailand.

1987. Public involvement in the Indian crocodile conservation programme. Pages 233-237 in G. J. W. Webb, S. C. Manolis and P. J. Whitehead, (eds). Wildife management: crocodiles and alligators. Surrey Beally and Sons Pvt. Ltd., Cleipping Norton, Australia. and H. R. Bustard. 1977. Studies on the Indian ghárial (Reptilia-Crocodilia) - V: Preliminary observation on maternal behavior. Indian For. 103: 671-678.

and

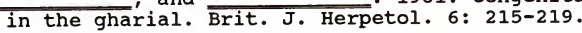

1981. Congenital defects and 1982a. Grographical distribution of the gharial in orissa, India. Brit. $J$. Herpitol. 6: 259-260.

, and $1982 \mathrm{~b}$. The snout of the gharial Brit. J. Herpetol. 6(7): 253-258.

S. Kar, and B. C. Choudhury. 1984. India: status of 'wild crocodiles. Pages $355-361$ in Crocodiles. Intl. Union Conserv. Nat. Natural Resours. Publ. New Ser. ISBN2-88032-306-1.

, and B. K. Tandan. 1978. Significance of the absence of optic nerves in a teratological specimen of Gavialis gangeticus (Reptilia: Crocodilia). Cheetal 19: 55-56.

singh, V. B. 1978. Status of the gharial in UP and its rehabilitation. J. Bombay Nat. Hist. Soc. $75(3)$ : 668683.

Smith, M. A. 1931. The fauna of British India including Ceylon and Burma. Reptilia and Amphibia. 1. London. Taylor and Francis Ltd, London. 185 pp.

Smythies, E. A. 1942. Big game shooting in Nepal. Thacker, spink \& Col, Ltd., Calcutta, India 174 pp.

Sokal, R. R., and F. J. Rohlf. 1981. Biometry 2nd ed.. W. H. Freeman \& Co., New York, N.Y. 859 pp.

Stainton, J. D. A. 1972. Forests of Nepal. Murray, London. 181 pp. 
Sunquist, M. E. 1979. The movement and activities of tigers Panthera tigris) in Royal Chitwan National Park, Nepal. PhD Dissertation Univ. of Minnesota. $169 \mathrm{pp}$.

Sunquist, F., and M. Sunquist. 1988. Tiger moon. The University of Chicago Press. Chicago and London. 176 pp.

Suvanakorn, P., and C. Youngprapakorn. 1987. Crocodile farming in Thailand. Pages 341-343 in G. J. W. Webb, S. C. Manolis and P. J. Whitehead, (eds). Wildlife management: crocodiles and alligators. Surrey Beally and Sons Pvt. Ltd., cleipping Norton, Australia.

Webb, G. J., and H. Missel. 1978. Movement and dispersal pattern of crocodylus porosus in some rivers of Arnham Land, Northern Australia. Aust. wildl. res. 5: 263-283.

H. Missel, J. Crawford, and M. J. Yerbury. 1978. Growth rates of Crocodylus porosus (ReptiliaCrocodilia) from Arnhem Land, Northern Australia. Aust. Wildl. Res. 5: 385-399.

Whitaker, R. 1974. Notes on behavior ecology and present status of the marsh crocodile in south India. Rep. Madras Snake Park Trust. 1-22 (mimeo).

- 1975. Status and the conservation of the Gharial. Herpetol. Rev. 6: 2-3.

- 1987. The management of crocodilians in India. Pages 63-72 in G. J. W. Webb, S. C. Manolis and P. J. Whitehead, (eds.) Wildiffe management crocodiles and alligators. Surrey Beally and Sons Pvt. Ltd., cleipping Norton, Australia.

and D. Basu 1983. The gharial: a review. J. Bombay Nat. Hist. Soc. 79: 531-548.

V. C. Rajmani, D. Basu, and V. Balakrishnan. 1974. Preliminary survey of the gharial.Madras Snake Park Trust Rep. 1-17.

and J. C. Daniel. 1978. The status of Asian crocodilians. Tiger Paper (FAO, Asia). 5: 12-17.

D. Basu, and C. A. Ross. 1979. Gharial survey and observation on the Ramganga River. Corbett National Park. UP, Hamadryad Suppl. 2: 1-17.

and $\mathrm{z}$. Whitaker. 1984. Reproductive biology of the mugger. J. Bombay Nat. Hist. Soc. 81: 297-317. 
Wilbur, H. M. 1975. A growth model for the turtle Chrysemys picta. Copeia 1975: 337-343.

Willan, R. S. M. 1965. The Chitwan Wildlife Sanctuary in Nepal. IUCN Bull. 8 (Morges, Switzerland).

Woodward, A., T. Hines, C. Abercombie, and C. Hope. 1984. Spacing patterns in alligator nests. J. of Herpetol. 18: 8- 12 .

M. L. Jennings and H. F. Percival. (in press). optimal time for collecting alligator eggs in Florida. Unpublished manuscript 1988. $15 \mathrm{pp}$.

Yangprapakorn, E. W. Cronin, and J. A. McNeely. 1971. Captive breeding of crocodiles in Thailand. Pages 98101 in Crocodiles: Proc. 1st working meet. Croc. sp. Group Intl. Union Cconserv. Nat. and Natural Resours. Publ. New Ser. Suppl. Pap. 32: 1-191. 
BIOGRAPHICAL SKETCH

Tirtha Man Maskey was born January 5, 1948 in Kathmandu, Nepal. In 1969, he received a B.S. in Biological Sciences from the Tribhuvan University, Kathmandu, Nepal. Shortly thereafter, he received the Colombo Plan

Scholarship, which enabled him to study forestry and applied sciences in the Indian Forest College, Deheradun, India, for 2 years. In August 1972, he was hired by the Department of Forestry of His Majesty's Government of Nepal to work as the first warden in the Royal Chitwan National Park; his duties were to establish and develop the country's first National Park. In January 1976, he joined the Department of Fisheries and Wildlife at the School of Natural Resources, Michigan State University, where he completed the degree of Master of Science in December 1977.

Upon his return to Nepal in 1978, he was reappointed as Chief Warden in the Royal Chitwan National Park, and for the next 5 years was involved in administration and management of the park, including association with large studies on the rhinoceros and tiger. In 1978, he initiated a study on hatching, rearing, and re-introduction of the endangered gharial in the Narayani River. In 1982, he was transferred 
to Langtang National Park, a mountain park in central Nepal, to develop that area into a functional park.

In August 1984, he entered the Ph.D program in the Department of Wildlife and Range Sciences, School of Forest Resources and Conservation, University of Florida. Upon completion of the degree, he will return to his position as wildife biologist with the National Parks and Wildlife Conservation Department, Nepal.

He has been married to Laxmi Maskey since 1974, and has two sons Jason, 13 and Asyush, 7. 
I certify that I have read this study and that in my opinion it conforms to acceptable standards of scholarly presentation and is fully adequate, in scope and quality, as a dissertation for the degree of Doctor of Phifosophy.

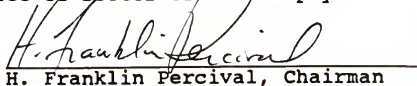

H. Franklin Percival, Chairman

Associate Professor of Forest

Resources and Conservation

I certify that I have read this study and that in my opinion it conforms to acceptable standards of scholarly presentation and is fully adequate, in scope and quality, as a dissertation for the degree of Doctor of Philosophy.

\section{Rouald 2. Dalusky Ronald F. Labisky \\ Professor of Forest Resources and Conservation}

I certify that I have read this study and that in my opinion it conforms to acceptable standards of scholarly presentation and is fully adequate, in scope and quality, as a dissertation for the degree of Doctor of Philosophy.

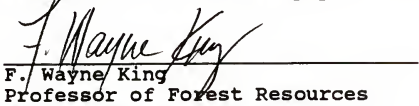

and Conservation

I certify that I have read this study and that in my opinion it conforms to acceptable standards of scholarly presentation and is fully adequate, in scope and quality, as a dissertation for the degree of Doctor of Philosophy.

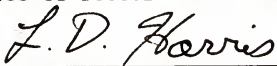

Lawrence D. Harris

Professor of Forest Resources and Conservation

I certify that I have read this study and that in my opinion it conforms to acceptable stamdards pf scholarly presentation and is fully adequate, in scope and quality, as a dissertation for the degree of Dooto $f$ Philosolphy.

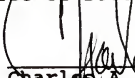

CharldSU. Woods

Professor of Zoology 
I certify that I have read this study and that in my opinion it conforms to acceptable standards of scholarly presentation and is fully adequate, in scope and quality, as a dissertation for the degree of Doctor of Philosophy.

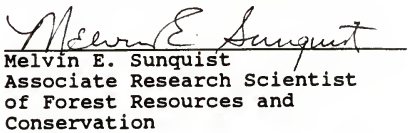

I certify that I have read this study and that in my opinion it conforms to acceptable standards of scholarly presentation and is fully adequate, in scope and quality, as a dissertation for the degree of Doctor of Philesophy.

May 1989

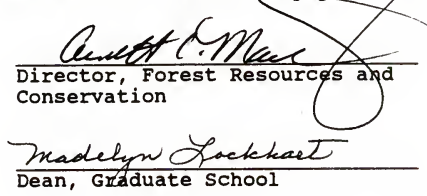

